\title{
Depositional constraints from detrital zircon geochronology of strata from multiple lithotectonic belts in south-central Maine, USA
}

\author{
Samuel F. A. Cartwright, David P. West, Jr. , and William H. Amidon \\ Department of Geology, Middlebury College, Middlebury, Vermont 05753, USA \\ *Corresponding Author: dwest@middlebury.edu
}

Date received: 05 October 2018 Date accepted: 21 January 2019

\begin{abstract}
The bedrock geology of south-central Maine is characterized by a series of fault-bounded lithotectonic belts that were accreted onto the Laurentian margin during Silurian-Devonian orogenesis. The multiple phases of deformation and metamorphism associated with this tectonism obscured most primary features in the protolith rocks, leading to uncertainties in their pre-accretionary history. Here we present the results of detrital zircon geochronology from five of these belts and make interpretations of their depositional ages, sediment provenance, and tectonic setting of deposition.

Detrital zircon from Silurian rocks of the Vassalboro Group from the easternmost structural margin of the Central Maine basin indicate sediment input in an extensional setting from both Laurentian and Ordovician volcanic arc sources. Results from Ordovician rocks of the Casco Bay Group of the Liberty-Orrington belt support earlier findings that these rocks have strong Gondwanan affinities. Detrital zircon from the Appleton Ridge Formation and Ghent Phyllite of the Fredericton trough are consistent with a sediment source of Gondwanan affinity with no evidence of Laurentian sediment input. These findings are consistent with that of Dokken et al. (2018) for older Fredericton trough strata (i.e., Digdeguash Formation) east of the Fredericton fault in southern New Brunswick. Two samples from the Jam Brook Complex reveal extreme differences in depositional age (Ordovician vs. Mesoproterozoic) and tectonic affinity and support the hypothesis that this narrow belt represents a fault complex containing a wide variety of stratigraphic units. Detrital zircon from Ordovician rocks of the Benner Hill Sequence indicate a sediment source of Gondwanan affinity with no Laurentian input.

Collectively, the pre-Silurian rocks of the Liberty-Orrington belt, Jam Brook Complex, Benner Hill Sequence, and Late Ordovician-Early Silurian strata from the Appleton Ridge and Ghent Phyllite in the Fredericton trough show Gondwanan affinities with no evidence of Laurentian se diment input.This information suggests that a barrier existed between the Laurentian margin and sources of Gondwanan sediment prior to about $435 \mathrm{Ma}$. In contrast, Silurian strata from the eastern structural margin of the Central Maine basin do show evidence of Laurentian sediment input, along with deposition in an extensional setting, thus signaling a fundamental change in tectonic regime.
\end{abstract}

\section{RÉSUMÉ}

La géologie du substratum rocheux dans le sud de la région centrale du Maine se caractérise par une série de ceintures lithotectoniques délimitées par des failles jadis accrétées à la marge laurentienne durant l'orogenèse siluro-dévonienne. Les multiples phases de déformation et de métamorphisme associées à ce tectonisme ont masqué la majeure partie des caractéristiques primaires des roches métamorphiques, entraînant des incertitudes à l'égard de leurs antécédents préaccrétionnaires. Nous présentons ici les résultats de la géochronologie des zircons détritiques de cinq de ces ceintures et des interprétations sur l'âge de leurs dépôts sédimentaires, la provenance des sédiments et le cadre tectonique des dépôts.

Les zircons détritiques des roches siluriennes du groupe de Vassalboro provenant de la marge structurale la plus orientale du bassin du centre du Maine indiquent un apport de sédiment dans un milieu techtonique d'extension en provenance de sources d'arc volcanique laurentiennes et ordoviciennes. Les résultats obtenus sur les roches ordoviciennes du groupe de la baie de Casco de la ceinture Liberty Orrington appuient les constatations antérieures prêtant à ces roches d'importantes affinités gondwaniennes. Les zircons détritiques de la formation d'Appleton Ridge et de Ghent Phyllite, dans la fosse de Fredericton, concordent avec une source sédimentaire ayant des affinités gondwaniennes, mais ne présentent aucune trace d'apport sédimentaire laurentien. Ces 
constatations concordent avec celles de Dokken et coll. (2018) à l'égard de strates plus anciennes de la fosse de Fredericton (c.-à-d. la formation de Digdeguash), à l'est de la faille de Fredericton, dans le sud du NouveauBrunswick. Deux échantillons du complexe de Jam Brook révèlent des différences extrêmes en lien avec l'âge des dépôts sédimentaires (ordovicien et mésoprotérozoïque) ainsi que l'affinité tectonique, appuyant ainsi l'hypothèse selon laquelle cette étroite ceinture représenterait un complexe de failles comportant une grande diversité d'unités stratigraphiques. Les zircons détritiques des roches ordoviciennes de la séquence de Benner Hill indiquent une source sédimentaire ayant des affinités gondwaniennes, mais exempte d'apports d'origine laurentienne.

Collectivement, les roches présiluriennes de la ceinture Liberty Orrington, du complexe de Jam Brook, de la séquence de Benner Hill ainsi que des strates d'Appleton Ridge et de Ghent Phyllite dans la fosse de Fredericton datant de la fin de l'Ordovicien et du début du Silurien présentent des affinités gondwaniennes, mais sont exemptes d'apports sédimentaires d'origine laurentienne. Cette information porte à croire à l'existence d'une barrière entre la marge laurentienne et les sources de sédiments gondwaniens avant les quelque 435 millions d'années. Par contre, les strates siluriennes de la marge structurale orientale du bassin du centre du Maine présentent, pour leur part, des traces d'apports sédimentaires laurentiens, ainsi que des dépôts dans un milieu techtonique d'extension, ce qui révèle un changement fondamental du régime tectonique.

[Traduit par la redaction]

\section{INTRODUCTION}

Detrital zircon geochronology has proven to be a powerful tool in unraveling the depositional histories of sedimentary basins preserved within orogenic belts. As pointed out by Gehrels (2014), the past two decades have seen an "explosion of publications" that report detrital zircon data, and the application of the technique to studies of northern Appalachian tectonics can be seen in numerous recently published papers (e.g., Bradley and O'Sullivan 2017; Karabinos et al. 2017; Kuiper et al. 2017; Dokken et al. 2018; Ludman et al. 2018; Reusch et al. 2018; Waldron et al. 2018). The area of south-central Maine west of Penobscot Bay (Fig. 1) contains a number of poorly understood lithotectonic belts that originated outboard of the North American continent (Laurentia) and were accreted during Silurian-Devonian mountain-building events (Tucker et al. 2001; Gerbi and West 2007). That accretionary process superimposed multiple episodes of ductile deformation and high-grade metamorphism on the sedimentary rocks in these terranes, obscuring much of their pre-accretionary history (e.g., their depositional ages, sediment provenance, and the tectonic settings of the basins themselves). However, the remarkable robustness of detrital zircon grains preserved in the metasedimentary rocks in these terranes can provide insight into this heretofore lost history. When combined with additional information from the geologic record, this knowledge can inform a more detailed understanding of the tectonic history of this portion of the northern Appalachian orogen.

The purpose of this paper is to present new detrital zircon geochronology from several enigmatic lithotectonic belts in south-central Maine with the goal of gleaning information on their pre-accretionary origins. This information consists of: (1) placing constraints on the depositional ages of rocks within each of the belts, (2) determining their sediment provenances (e.g., derived from Laurentian, Gondwanan, or Iapetus/Rheic Ocean volcanic arc sources), and (3) combining this information with previously published data to place constraints on the histories of these rock units prior to Silurian-Devonian orogenesis.

\section{GEOLOGIC OVERVIEW}

The study area is located in south-central Maine just west of Penobscot Bay (Fig. 1) where stratified rocks were multiply deformed, metamorphosed, and intruded by several generations of plutons during Silurian-Devonian orogenic activity (Tucker et al. 2001; Gerbi and West 2007). Based on differences in age and internal stratigraphy, these stratified rocks are divided into several different lithotectonic sequences separated from one another by faults and/or shear zones (Fig. 2, Table 1). These include four regionally extensive lithotectonic belts (Central Maine, Liberty-Orrington, Fredericton, and St. Croix), as well as three enigmatic less extensive belts (Jam Brook, Clarry Hill, and Benner Hill). The geology within each of these belts has been described elsewhere, but a general overview of each is provided in the following sub-sections, progressing across strike from northwest to southeast. The reader is referred to Figure 2 for the spatial distribution of these lithotectonic belts in the study area, and Table 1 provides an overview of the stratigraphy within each. The interested reader is referred to Berry and Osberg (1989), West et al. (2003), and Berry et al. (2016) for additional details on the stratigraphy in the area of Figure 2.

\section{Central Maine basin}

The Central Maine basin underlies the western portion of the study area and represents a regionally extensive, Late Ordovician to Early Devonian assemblage of marine sedimentary rocks (Osberg 1988). The basin, as presently preserved in central Maine, is up to $100 \mathrm{~km}$ wide and interpreted to have originally formed between the Taconic orogeny-modified margin of eastern North America (Laurentia) and a series of outboard pre-Silurian Gondwana-derived terranes (Robinson et al. 1998; van Staal et al. 2009). In our study area (Fig. 2), only the eastern structural margin of the Central Maine basin is exposed and it contains deformed and metamorphosed turbidites of the Late Ordovician (?) to Silurian Vassalboro Group (Marvinney et al. 


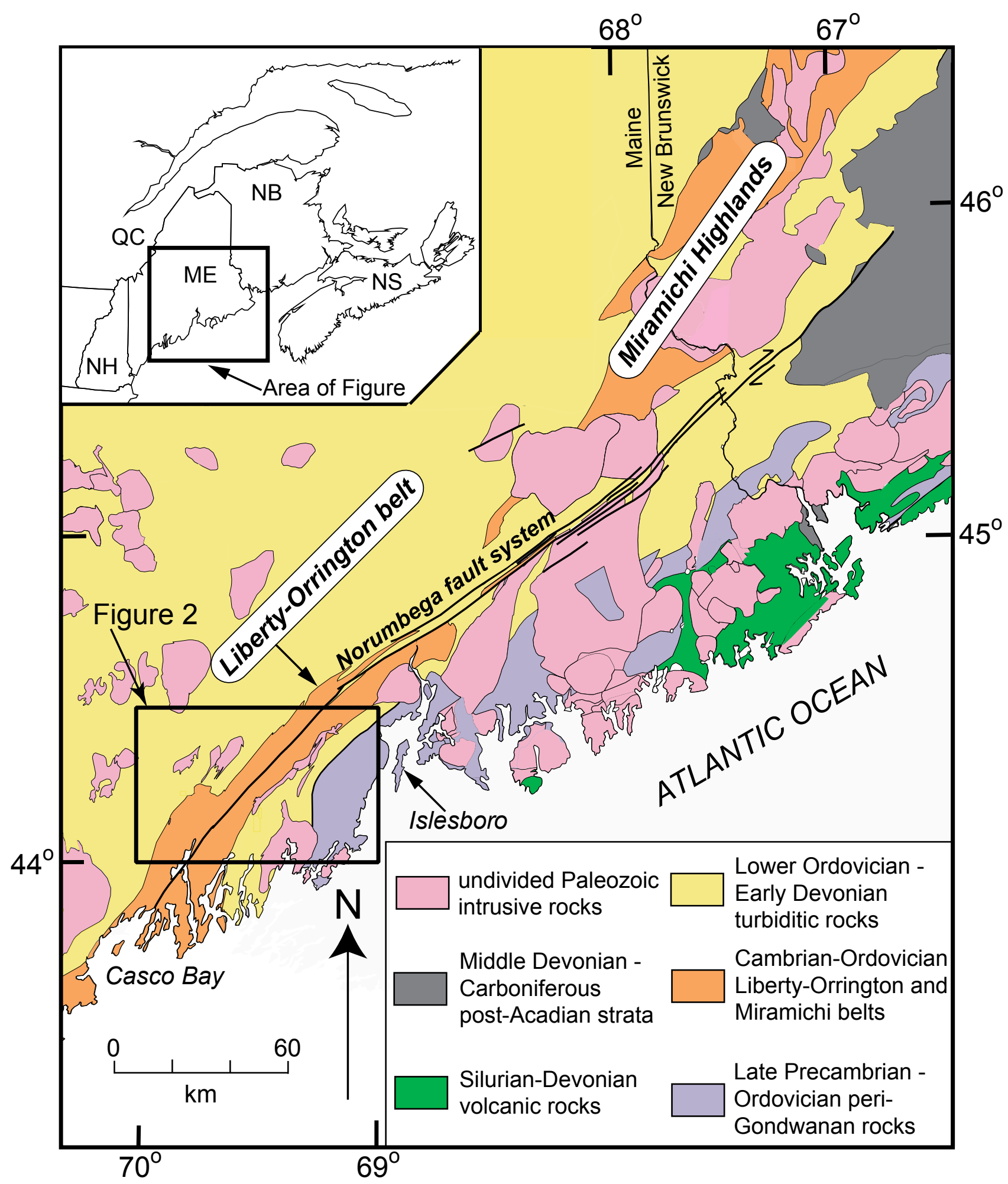

Figure 1. Generalized geologic map of part of Maine and New Brunswick (modified from Bradley et al. 2000). Box outlines the area of Figure 2.

2010). Importantly, fossils from the Waterville Formation within the Vassalboro Group contain Llandoverian to Wenlockian fossils (Pankiwskyj et al. 1976; Orr and Pickerill 1995). Lithologically similar but unfossiliferous rocks of the Hutchins Corner and Mayflower Hill formations conform- ably underlie and overlie the Waterville Formation, respectively (Marvinney et al. 2010). Where the stratigraphic position of rocks relative to the Waterville Formation cannot be ascertained, they are simply assigned to the Vassalboro Group. One sample (SC-9) was collected and analyzed from 


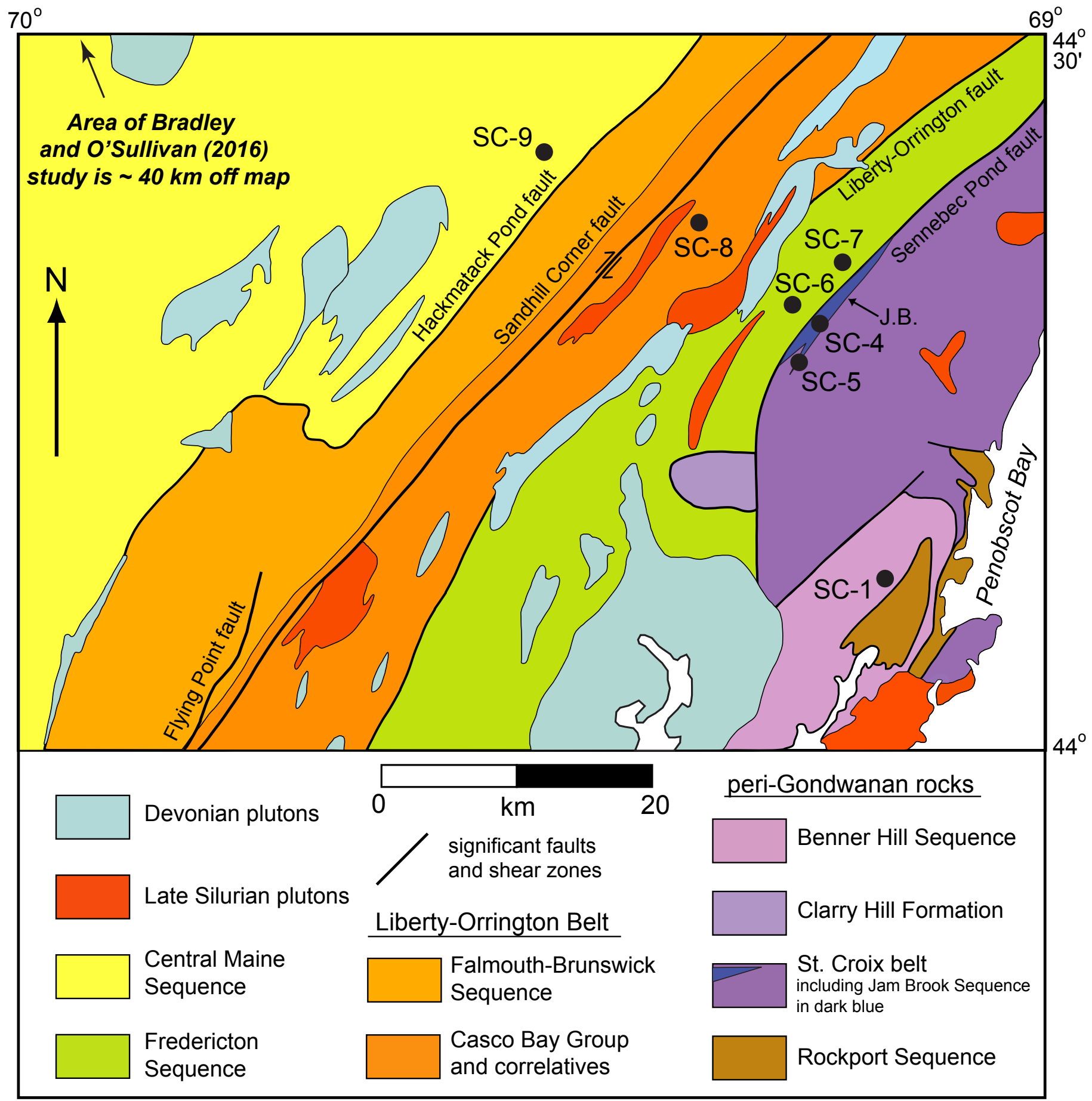

Figure 2. Generalized geologic map of south-central Maine showing lithotectonic belts, bounding faults, and sample locations (modified from Tucker et al. 2001; Gerbi and West 2007).

the easternmost part of the belt preserved in the study area. Bradley and O'Sullivan (2017) recently completed a detailed detrital zircon study of strata from the northwestern margin of the Central Maine basin, and Ludman et al. (2018) present detrital zircon data from the easterly portions of the basin. The results of these studies will be compared with our findings later in the paper.

\section{Liberty-Orrington belt}

The Liberty-Orrington belt is exposed immediately to the southeast of the Central Maine basin and is a relatively narrow $(<25 \mathrm{~km})$, approximately $175 \mathrm{~km}$-long belt that contains metamorphosed Middle to Upper Ordovician volcanic and volcanogenic sedimentary rocks of the Falmouth-Brunswick Group and Casco Bay Group (Hussey et 
Table 1. Simplified stratigraphic chart of the units discussed in this paper.

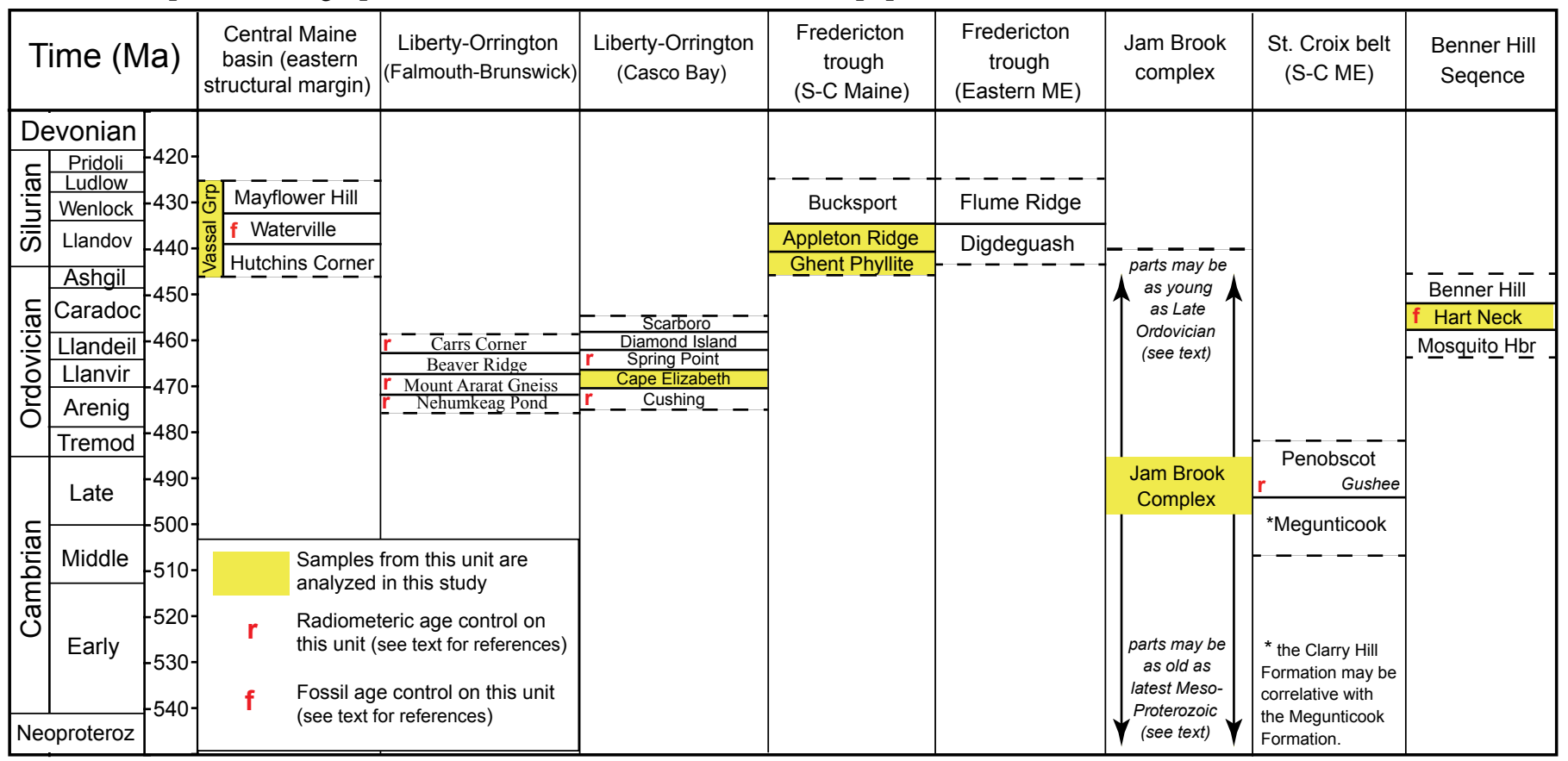

al. 2010). In south-central Maine, these rocks are interpreted to represent an assemblage of volcanic arc to backarc rocks of Gondwanan affinity (i.e., Ganderia) that were accreted to the Laurentian margin during the Silurian (West et al. 2003, 2004). One sample (SC-8) analyzed in this study was collected from the Cape Elizabeth Formation of the Casco Bay Group. Metasedimentary rocks of the Cape Elizabeth Formation are conformably overlain by metavolcanic rocks of the Spring Point Formation - the protoliths of which were erupted at $469 \pm 3 \mathrm{Ma}$ (based on a U-Pb zircon crystallization age from Tucker et al. 2001). Detrital zircon ages from the Wilson Cove Member of the underlying Cushing Formation are reported in West et al. (2008).

\section{Fredericton trough}

The Fredericton trough in south-central Maine consists of metamorphosed metasedimentary rocks of the Bucksport Formation, Appleton Ridge Formation, and Ghent Phyllite. These rocks have been tentatively correlated with Silurian rocks of the Kingsclear Group in southwestern New Brunswick (McKerrow and Ziegler 1971; Fyffe et al. 2011). In this study, detrital zircon from one sample of the Appleton Ridge Formation (SC-6) and one sample of the Ghent Phyllite (SC-7) were analyzed. Detrital zircon ages have recently been published from various formations in the Kingsclear Group in New Brunswick (Dokken et al. 2018) and adjacent eastern Maine (Ludman et al. 2018); these results will be discussed later in the paper.

\section{Jam Brook Complex}

The Jam Brook Complex, located just to the east of the
Sennebec Pond fault, contains a wide variety of relatively thin $(<100 \mathrm{~m})$ fault-bounded metasedimentary units contained within a belt up to $2 \mathrm{~km}$ wide and $15 \mathrm{~km}$ long. These rocks were originally interpreted by Bickel (1976) to represent a single stratigraphic unit (the Jam Brook Formation), but they are currently interpreted to represent different stratigraphic units juxtaposed by a complex series of strike-parallel faults (Berry et al. 2016). Rock types within what is now viewed as a structural complex associated with the Sennebec Pond fault include quartzite, metaconglomerate, marble, calc-silicate gneiss, mica schist, and felsic gneiss. Depositional age control on these individual rock types is lacking, but lithologic similarities suggest correlations with stratigraphic units to the east (e.g., parts of the Rockport Group and Cookson Group) suggesting an age range of Precambrian to Ordovician for the various rock types within the complex (Berry et al. 2016). Detrital zircon from two quartzite samples (SC-4 and SC-5) within the Jam Brook Complex were analyzed in this study. No other age control (fossils or geochronology) is available from rocks of the Jam Brook Complex.

\section{St. Croix belt (Cookson Group)}

The St. Croix belt extends over $200 \mathrm{~km}$ from the present study area along the western side of Penobscot Bay through eastern Maine (Ludman 1987) and into southern New Brunswick (Fyffe and Riva 1990; Fyffe et al. 2011). The belt contains the rocks of the Cookson Group, which are dominated by Middle Cambrian to Late Ordovician metasedimentary and minor metavolcanic rocks. In the study area, the Cookson Group contains rocks of the Penobscot and Megunticook formations and these units have 
been tentatively correlated with the Calais and Crocker Hill formations, respectively, in eastern Maine and coastal New Brunswick. $\mathrm{U}-\mathrm{Pb}$ dating of igneous zircon crystallization in metavolcanic rocks from the upper part of the Penobscot Formation in the study area reveal latest Cambrian to earliest Ordovician eruptive ages (Tucker et al. 2001; Berry et al. 2016), consistent with fossil evidence in southern New Brunswick (Fyffe and Riva 1990). In addition, immobile trace element geochemistry in mafic metavolcanic rocks of the Penobscot Formation is consistent with formation in an island arc system generated through ocean-ocean subduction (Burke 2016). Unfortunately, a sample collected from the Megunticook Formation (SC-3) did not yield a sufficient number of zircon grains for analysis.

\section{Clarry Hill Formation}

The Clarry Hill Formation consists of migmatitic schist contained within a thrust fault bounded klippe that is structurally above the Kingsclear Group of the Fredericton trough (Tucker et al. 2001; Berry et al. 2016); these rocks have been correlated with the Megunticook Formation of the St. Croix Group (previous references). Unfortunately, a sample collected from the Clarry Hill Formation (SC-2) did not yield a sufficient nu mber of zircon grains for analysis. No other age control (i.e., fossils or geochronology) is available from rocks of the Clarry Hill Formation and thus proposed correlations with the Megunticook Formation remain untested.

\section{Benner Hill Sequence}

The Benner Hill Sequence (Osberg and Guidotti 1974) is a spatially restricted, fault-bounded assemblage of Ordovician metasedimentary rocks that have unclear relationships with surrounding terranes (Berry et al. 2000, 2016). The sequence contains the Benner Hill, Hart Neck, and Mosquito Harbor formations and, importantly, the Hart Neck Formation contains deformed brachiopods which indicate a Caradocian depositional age (Boucot et al. 1972). One sample analyzed in this study was collected from the fossiliferous Hart Neck Formation (SC-1).

\section{METHODS}

Nine $\sim 10 \mathrm{~kg}$ samples were collected from metasandstone/ siltstone lithologies from the different lithotectonic belts described above (Fig. 3 shows representative rock types). The sample locations are plotted on Figure 2 and corresponding UTM coordinates and notes on the collected rock types are provided in Appendix A. After thin sections were made for petrographic description (details in Cartwright 2018), each sample was disaggregated by standard crushing and milling techniques. This material was then sieved to obtain a $<250 \mu \mathrm{m}$ fraction which was washed to remove dust and dried before magnetic minerals were removed, first with a hand magnet, and then with the aid of a Frantz Isodynamic
Magnetic Separator. The non-magnetic fraction was then subjected to heavy liquid settling separation using Methylene Iodide, which has a specific gravity of 3.3. To remove remaining high density, low magnetism minerals such as pyrite and rutile, the mineral separates were subjected to 45-minute HF-nitric acid baths, leaving separates that in most cases largely consisted of zircon.

The purified zircon separates were mounted in epoxy and polished to reveal cross-sections parallel to the c-axis. Each separate was then imaged using cathodoluminescence on a Tescan Vega3 Scanning Electron Microscope to reveal the details of internal zonation and the presence of cracks and alteration zones, which were avoided during analysis (examples shown in Fig. 4; the details of all the samples are provided in Cartwright 2018). The abundance of ${ }^{238} \mathrm{U},{ }^{235} \mathrm{U},{ }^{206} \mathrm{~Pb}$, and ${ }^{207} \mathrm{~Pb}$ were measured from the unknowns and a suite of standards using an Elemental Scientific NWR-213 laser attached to a Thermo Scientific iCAP-Q quadrupole mass spectrometer at Middlebury College in Vermont. Analysis spots were randomly chosen so that the data collected would not be biased towards zircons of a particular size or texture. For large zoned grains, a priority was placed on targeting apparent xenocrystic cores because, unlike secondary growth, they are indicative of the age of original crystallization.

The primary zircon standard 91500 was analyzed during each analysis session to correct for isotopic fractionation (Wiedenbeck et al. 2004). Four secondary standards (94-35, Plešovice, R33, and Tan-BrA) were also analyzed to assess the accuracy and precision of the calculated $\mathrm{U}-\mathrm{Pb}$ dates. These standards were analyzed in blocks interspersed between sets of six or eight unknowns. Each block consisted of two primary (91500) and two secondary (varied depending on available surface area for new laser spots) zircon standards; every other block also included an analysis of NIST SRM610 glass used to monitor the long-term performance of the instrument. The zircon standards used have the following confirmed ages: $91500=1065.4 \pm 0.5 \mathrm{Ma}, 94-35=$ $55.5 \pm 1.5 \mathrm{Ma}$, Plešovice $=337.16 \pm 0.11 \mathrm{Ma}, \mathrm{R} 33=419.3 \pm$ $0.4 \mathrm{Ma}, \mathrm{Tan}-\mathrm{BrA}=2512.24 \pm 0.71 \mathrm{Ma}$ (Wiedenbeck et al. 2004, Klepeis et al. 1998; Sláma et al. 2008; Black et al. 2004; Gehrels 2018). Analyses made during our study yielded the following weighted mean ages and $2 \sigma$ errors calculated from ${ }^{206} \mathrm{~Pb} /{ }^{238} \mathrm{U}$ ratios: $94-35=55.5 \pm 0.8 \mathrm{Ma}(\mathrm{n}=32)$, Plesovice $=$ $345.9 \pm 2.6 \mathrm{Ma}(\mathrm{n}=57), \mathrm{R} 33=420.8 \pm 2.5 \mathrm{Ma}(\mathrm{n}=92)$, Tan$\mathrm{BrA}=2510 \pm 14 \mathrm{Ma}(\mathrm{n}=66)$.

A laser spot size of $22 \mu \mathrm{m}$ was used for each ablation, preceded by a two-second $50 \mu \mathrm{m}$ "cleaning shot". We used a laser energy of $4.00 \mathrm{~J} / \mathrm{cm}^{2}$, a frequency of $10 \mathrm{~Hz}$, dwell time of 20 seconds, and a blank collection of roughly 20 seconds. Initial data reduction was accomplished using the Iolite data reduction package. Laser-shot time series showing multiple isotopic domains or strongly increasing or decreasing signals were discarded. Likewise, analyses $>15 \%$ discordant were eliminated from the final dataset, resulting in 64-164 accepted $\mathrm{U}-\mathrm{Pb}$ dates for each sample.

The data of interest in this output are the averaged ${ }^{207} \mathrm{~Pb} /{ }^{235} \mathrm{U},{ }^{206} \mathrm{~Pb} /{ }^{238} \mathrm{U}$, and ${ }^{207} \mathrm{~Pb} /{ }^{206} \mathrm{~Pb}$ isotope ratios for each 

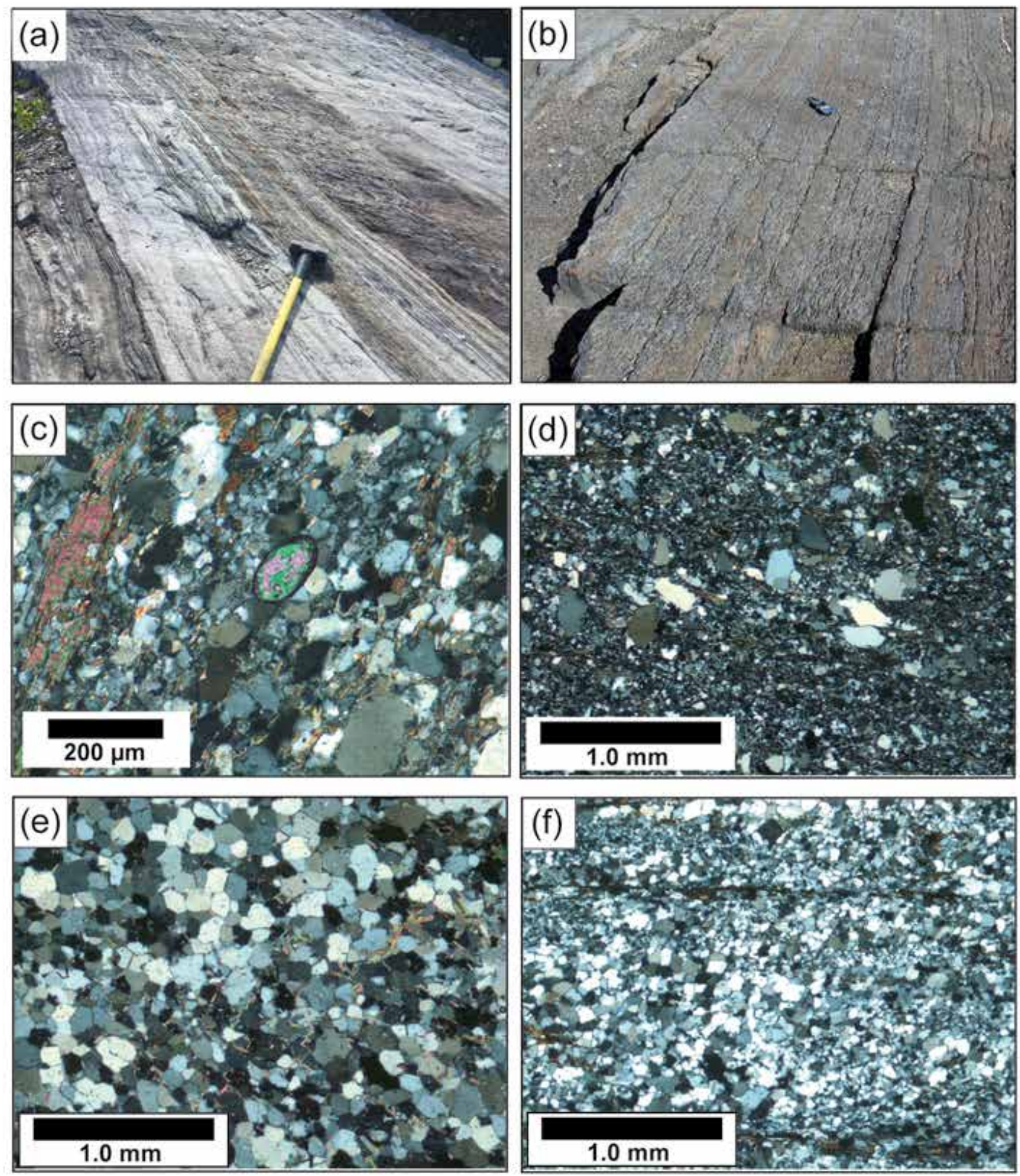

Figure 3. Representative outcrop photographs and thin section photomicrographs from the samples analyzed. (a) SC-8 sample location: interlayered quartzite (beneath hammer handle) and mica schist (beneath hammer head) of the Cape Elizabeth Formation of the Casco Bay Group. (b) SC-6 sample location: interlayered feldspathic quartzite and staurolite schist of the Appleton Ridge Formation of the Fredericton trough. (c) SC-9 photomicrograph (XPL) of biotite granofels from the Vassalboro Group of the Central Maine basin (note the large highly birefringent zircon grain in the center). (d) SC-7 photomicrograph (XPL) of metasiltstone of the Ghent Phyllite of the Fredericton trough. (e) SC-5 photomicrograph (XPL) of quartzite from the Jam Brook Complex. (f) SC-4 photomicrograph (XPL) of quartzite from the Jam Brook Complex. 


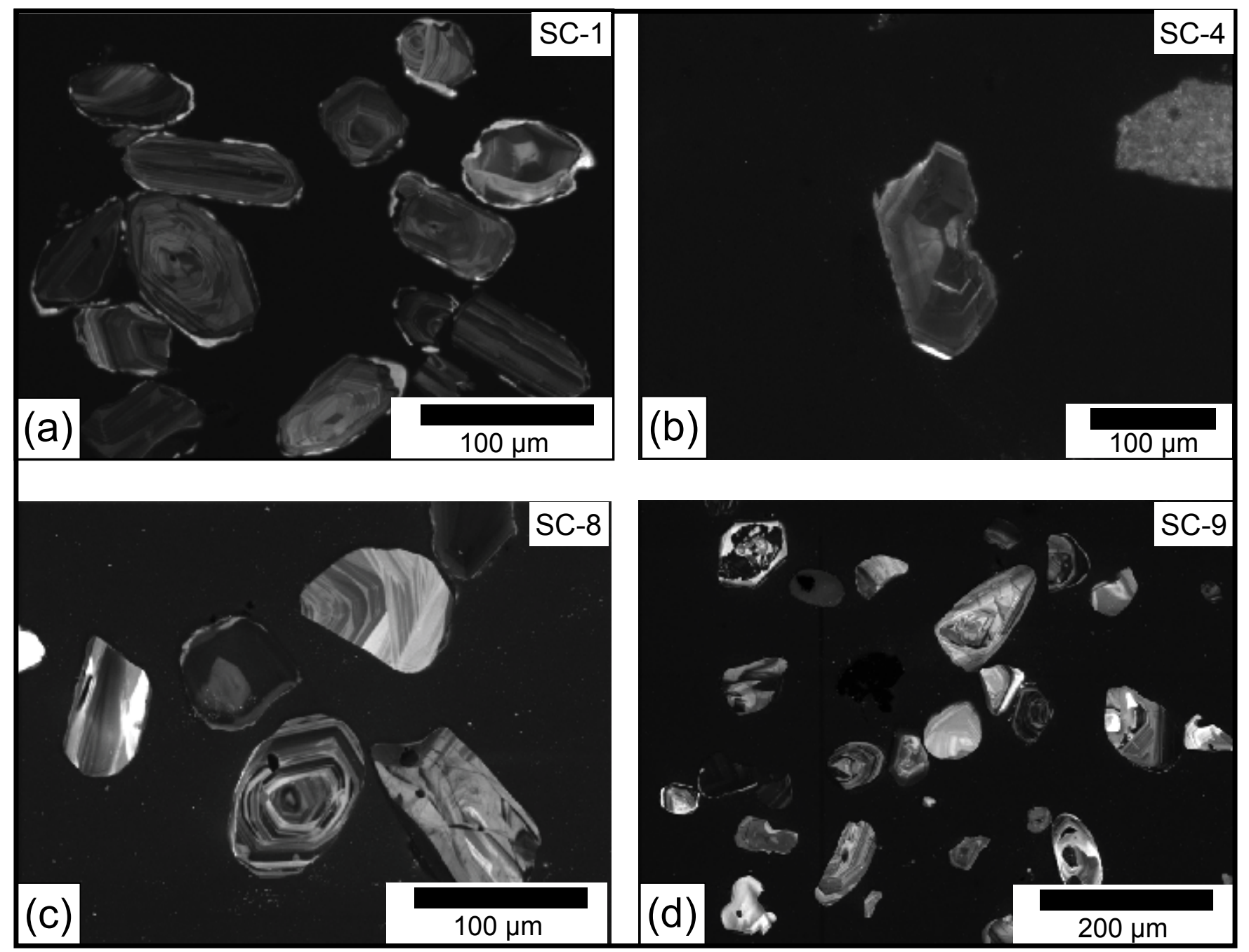

Figure 4. Representative cathodoluminescence images of selected zircons from samples analyzed. Sample numbers are shown in the upper right corner of each image.

analyzed grain as well as their associated errors and ages. Quoted uncertainties reflect the $2 \sigma$ propagated uncertainties as exported from Iolite, which includes a propagated term for excess scatter in the secondary standards (e.g., step 5 in Horstwood et al. 2016). Quoted uncertainties do not include propagated uncertainties for long-term variance of the secondary standards, decay constant, or common- $\mathrm{Pb}$ correction. Concordia diagrams were constructed using the Isoplot 4.1 add-in for Microsoft Excel (Ludwig 2012).

\section{RESULTS}

A table of U-Pb LA-ICP-MS analytical results from each sample is provided in Appendix B. Probability density plots (PDPs) for each sample, the standard way that detrital zircon data are portrayed, are shown in Figure 5. Hand sample photographs, thin section photomicrographs, cathodoluminescence images, $\mathrm{U}-\mathrm{Pb}$ concordia diagrams, and kernel density plots from each of the analyzed samples are available in Cartwright (2018). Basic information on the results are provided below, with analysis and interpretations of these results provided in the Discussion.

\section{Eastern Central Maine basin (Vassalboro Group)}

Sample SC-9 is a calcareous granofels (Fig. 3c) from well-bedded biotite and calc-silicate granofels of the Vassalboro Group exposed near the eastern structural margin of the Central Maine basin. Mineral separation yielded abundant detrital zircon displaying a variety of sizes, external morphologies, and internal textures (Fig. $4 \mathrm{~d}$ ). U-Pb isotopic ratios were obtained for 168 detrital zircon grains from the sample and of the 167 successful analyses, 161 plotted within $15 \%$ of concordia. The distribution of calculated zircon ages (Fig. 5a) shows prominent peaks at $\sim 460 \mathrm{Ma}, 1060$ $\mathrm{Ma}$, and $1600 \mathrm{Ma}$ with a minor peak at $2670 \mathrm{Ma}$. The three youngest detrital zircon dates from the sample are between 420-425 Ma. 


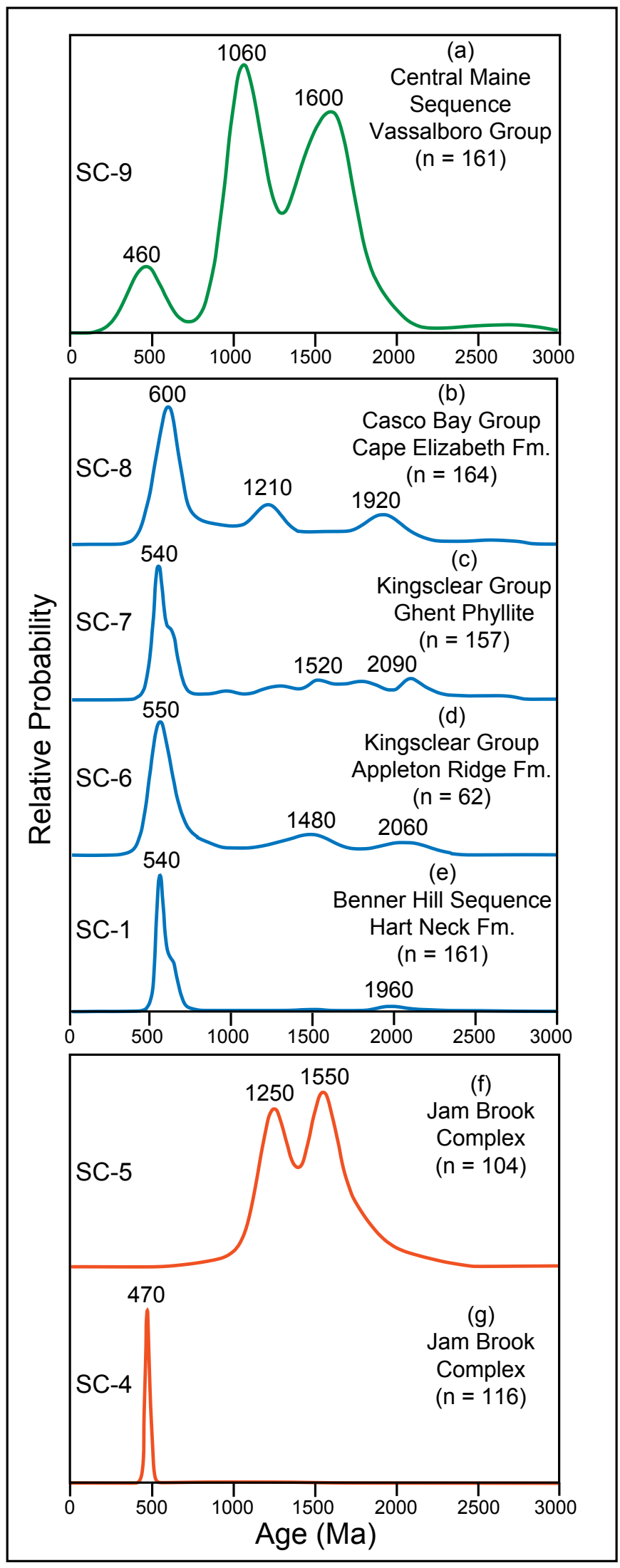

Figure 5. Normalized detrital zircon probability density plots of samples in this study. The sample locations are shown in Figure 2 and the data is provided in the Appendix B.

\section{Liberty-Orrington belt (Cape Elizabeth Formation)}

Sample SC-8 is a mica- and feldspar-bearing quartzite from interlayered quartzite and sillimanite-bearing schist of the Cape Elizabeth Formation of the Casco Bay Group (Fig. 3a). Mineral separation yielded an abundance of detrital zircon displaying a variety of sizes (up to $100 \mu \mathrm{m}$ across), external morphologies, and internal textures (Fig. 4c). U-Pb isotopic ratios were obtained for 176 detrital zircon grains from the sample and of the 175 successful analyses, 164 plotted within $15 \%$ of concordia. The distribution of calculated zircon ages (Fig. 5b) shows a very prominent peak at $\sim 600 \mathrm{Ma}$, with broader, smaller peaks centered at $\sim 1210$ and $1920 \mathrm{Ma}$. The three youngest detrital zircon dates from the sample are 469 and 481(2) Ma.

\section{Fredericton trough (Ghent Phyllite)}

Sample SC-7 is a fine-grained metasiltstone (Fig. 3d) collected from interlayered phyllite and metasiltstone of the Ghent Phyllite (garnet zone) near the eastern margin of the Fredericton trough. Mineral separation provided a large number of mostly clear, internally zoned zircons in the 50-100 $\mu \mathrm{m}$ size range. $\mathrm{U}-\mathrm{Pb}$ isotopic ratios were obtained for 200 detrital zircon grains from the sample and of the 195 successful analyses, 157 plotted within $15 \%$ of concordia. The distribution of calculated zircon ages (Fig. 5c) shows a very prominent peak at $\sim 540 \mathrm{Ma}$ with a noticeable shoulder at $200 \mathrm{Ma}$. Numerous zircons have older dates in the 900$2200 \mathrm{Ma}$ range with the larger of these small broad peaks being at $\sim 1520$ and $2090 \mathrm{Ma}$. The three youngest detrital zircon dates are 435, 468, and $480 \mathrm{Ma}$.

\section{Fredericton trough (Appleton Ridge Formation)}

Sample SC-6 is from a cordierite-bearing, feldspathic metasandstone from interlayered feldspathic metasandstone and staurolite-bearing schist of the Appleton Ridge Formation (Fig. 3b). Mineral separation produced a large number of fragmented grains that display complex internal zoning. $\mathrm{U}-\mathrm{Pb}$ isotopic ratios were obtained for 96 detrital zircon grains from the sample and of the 87 successful analyses, only 62 plotted within $15 \%$ of concordia. The distribution of calculated zircon dates (Fig. $5 \mathrm{~d}$ ) shows a very prominent peak at $\sim 550 \mathrm{Ma}$ with older, smaller broad peaks being at $\sim 1480$ and $2060 \mathrm{Ma}$. The three youngest detrital zircon dates are 422, 494, and $499 \mathrm{Ma}$.

\section{Jam Brook Complex (two samples)}

Sample SC-5 is a light grey to white quartzite (Fig. 3e) displaying flattened quartz clasts up to $3 \mathrm{~cm}$ in length. Zircons separated from this sample showed more size and shape variability than other samples in the study, with a large proportion of the grains being $<20 \mu \mathrm{m}$ fragments which were too small to analyze. $\mathrm{U}-\mathrm{Pb}$ isotopic ratios were obtained for 114 detrital zircon grains from the sample and of the 106 
successful analyses, 104 plotted within $15 \%$ of concordia. The distribution of calculated zircon dates (Fig. 5f) shows two prominent peaks at $\sim 1250$ and $1550 \mathrm{Ma}$. Only two detrital zircon dates from this sample are less than $1000 \mathrm{Ma}$ (960 and $969 \mathrm{Ma}$ ).

Sample SC-4 is a light grey orthoquartzite (Fig. 3f). Mineral separation yielded unusually euhedral zircon as compared with other samples in the study and xenocrystic cores are uncommon in the zircons imaged (Fig. $4 \mathrm{~b}$ ). U-Pb isotopic ratios were obtained for 120 detrital zircon grains (all successful), with 116 of these analyses plotting within $15 \%$ of concordia. The distribution of calculated zircon dates (Fig. $5 \mathrm{~g}$ ) shows a very prominent narrow peak at $\sim 470 \mathrm{Ma}$ with only two dates (952 and $1216 \mathrm{Ma}$ ) outside the 439-529 Ma age range associated with this peak.

\section{Benner Hill Sequence (Hart Neck Formation)}

Sample SC-1 is a rusty-weathering quartzite from the top of the Hart Neck Formation. Mineral separation produced the cleanest zircon separate of the study, which consists of grains with uniform sizes and morphologies (Fig. 4a). U-Pb isotopic ratios were obtained for 168 detrital zircon grains (all successful) with 161 of these analyses plotting within $15 \%$ of concordia. The distribution of calculated zircon dates (Fig. 5e) shows a very prominent narrow peak at $\sim 540 \mathrm{Ma}$ with a noticeable shoulder at $\sim 600 \mathrm{Ma}$. Much smaller peaks are found at $\sim 1470$ and $1960 \mathrm{Ma}$. The three youngest dates calculated are 302,410 , and $466 \mathrm{Ma}$, though the vast majority of the dates are between 500 and $600 \mathrm{Ma}$.

\section{DISCUSSION}

\section{Constraints on depositional ages}

With the exception of the Hart Neck Formation of the Benner Hill Sequence, none of the metasedimentary rocks exposed in the study area contain fossils that can be used to constrain their original depositional ages. Although $\mathrm{U}-\mathrm{Pb}$ crystallization ages from conformable metavolcanic units can provide absolute age control on deposition (discussed for relevant samples below), most of the age assignments for stratified rocks in the study area are based on along-strike correlations to the northeast where the rocks have not been extensively recrystallized by the combined effects of ductile deformation and amphibolite-facies metamorphism. Berry and Osberg (1989) provided a comprehensive overview of many of the individual units in the study area and discuss likely correlatives, but depositional age assignments for many of the stratified rocks exposed in the area of Figure 2 have few constraints.

Detrital zircon geochronology can provide an independent means for constraining the depositional ages of sedimentary/metasedimentary rocks. These constraints are based on the "law of detrital zircons" which states that a sedimentary unit cannot be any older than the youngest zircon grain it contains (Gehrels 2014). In other words, the youngest detrital zircon age obtained from a sample provides a maximum depositional age. However, the single youngest detrital zircon age acquired from a sample should be interpreted with caution as post-crystallization $\mathrm{Pb}$-loss or post-depositional zircon growth during metamorphism can lead to anomalously young ages in detrital zircon populations, resulting in underestimates of maximum depositional age (Gehrels 2014).

In order to determine best practices for the interpretation of maximum depositional ages from detrital zircon data, Dickinson and Gehrels (2009) compared several different methods for determining the "youngest grain" against known, biostratigraphically constrained depositional ages of Mesozoic sandstone from the Colorado Plateau. They found the greatest precision in a method that involved taking the weighted mean age (incorporating analytical and systematic errors) of the youngest cluster of three or more grains that overlapped in age within errors of $2 \sigma$. In this study, to provide an independent estimate of the maximum depositional age of a sampled unit, we have adopted the Dickinson and Gehrels (2009) approach and use a weighted mean (weighted by the inverse square of $2 \sigma$ ) of the three youngest grain ages overlapping in $2 \sigma$ that are not considered outliers given known age constraints. The maximum depositional ages determined using this method are presented in Table 2 and discussion of additional constraints for individual units is provided below.

\section{Eastern Central Maine basin Vassalboro Group (SC-9)}

The Central Maine basin can generally be divided into a western section (focus of the detrital zircon study of Bradley and O'Sullivan, 2017) and an eastern section (focus of the detrital zircon study of Ludman et al. 2018, and the location of our sample SC-9). The stratigraphy in the eastern section includes the Vassalboro Group which contains (from oldest to youngest) the Hutchins Corner, Waterville, and Mayflower Hill formations (Marvinney et al. 2010). The Waterville Formation contains Late Llandovery to Wenlock fossils (438-427 Ma using the time scale of Melchin et al. 2012); however, the unfossiliferous Hutchins Corner and Mayflower Hill formations are lithologically similar and cannot be distinguished from one another unless depositional relationships with the Waterville Formation can be determined using primary sedimentary features. Due to structural complexity and the effects of overprinting high-grade metamorphism, these relationships are rarely available in southcentral Maine and thus a general designation of "Vassalboro Group" is used when the Waterville Formation cannot serve as a direct stratigraphic marker (Marvinney et al. 2010). Detrital zircon from our sample SC-9, collected from the undivided Vassalboro Group, provides a maximum depositional age of $422 \pm 20 \mathrm{Ma}$ using the conservative approach of Dickinson and Gehrels (2009). Given the $>427 \mathrm{Ma}$ depositional age of the Waterville Formation, it seems likely, but not required (given the uncertainty range), that the rocks 
Table 2. Maximum depositional ages of sampled formations as indicated by youngest individual grains and grain clusters (additional information on independent depositional age constraints are discussed in the text).

\begin{tabular}{ccccccc}
\hline Sample & Lithotectonic Belt & Formation/Unit & $\begin{array}{c}\text { Youngest } \\
\text { Grain }(\mathrm{Ma})\end{array}$ & $\begin{array}{c}\text { Error } \\
(2 \sigma)\end{array}$ & $\begin{array}{c}\text { Youngest } \\
\text { Cluster* }(\mathrm{Ma})\end{array}$ & $\begin{array}{c}\text { Error } \\
(2 \sigma)\end{array}$ \\
\hline SC-9 & Central Maine & Vassalboro Group & 420 & \pm 34 & 422 & \pm 20 \\
SC-8 & Liberty-Orrington & Cape Elizabeth Fm. & 469 & \pm 43 & 478 & \pm 20 \\
SC-7 & Fredericton & Ghent Phyllite & 435 & \pm 32 & 476 & \pm 18 \\
SC-6 & Fredericton & Appleton Ridge Fm. & 422 & \pm 23 & 489 & \pm 16 \\
SC-5 & Jam Brook & Jam Brook & 960 & \pm 170 & 975 & \pm 64 \\
SC-4 & Jam Brook & Jam Brook & 439 & \pm 18 & 440 & \pm 13 \\
SC-1 & Benner Hill & Hart Neck Fm. & $466^{* *}$ & \pm 24 & 501 & \pm 12 \\
\hline
\end{tabular}

* weighted mean of the three youngest grains with ages overlapping in $2 \sigma$ error, weighted by the inverse square of $2 \sigma$ (after Dickinson and Gehrels, 2009).

** two younger ages of $302 \mathrm{Ma}$ and $410 \mathrm{Ma}$ are interpreted to reflect $\mathrm{Pb}$ loss and were excluded from consideration due to the presence of Ordovician fossils in the unit.

along the eastern-most margin of the Central Maine basin where sample SC-9 was collected should be assigned to the Mayflower Hill Formation rather than the Hutchins Corner Formation.

\section{Cape Elizabeth Formation (SC-8)}

The depositional age of the Cape Elizabeth Formation of the Casco Bay Group is independently and tightly constrained between a $465 \pm 4$ Ma zircon from a volcanic rock in the underlying Cushing Formation (Hussey et al. 2010) and a $469 \pm 3$ Ma zircon from a volcanic rock in the overlying Spring Point Formation (Tucker et al. 2001). The maximum depositional age determined in this study $(478 \pm 20 \mathrm{Ma})$ is consistent with the $\sim 465-470 \mathrm{Ma}$ depositional age constraint provided by these previously determined $\mathrm{U}-\mathrm{Pb}$ ages.

\section{Ghent Phyllite and Appleton Ridge Formation (SC-7 and SC-6)}

Depositional ages of formations within the Fredericton trough in south-central Maine (the Appleton Ridge Formation, Bucksport Formation, and Ghent Phyllite) are based primarily on tentative correlations with rocks of the Kingsclear Group in southern New Brunswick (McKerrow and Ziegler 1971; Fyffe et al. 2011; Dokken et al. 2018). The Digdeguash Formation of the Kingsclear Group in New Brunswick, a suggested correlative for the Appleton Ridge Formation, contains early Llandovery graptolites (441.6 to 440.8 Ma using the time scale of Melchin et al. 2012). In south-central Maine, the only depositional age constraint on rocks in the Fredericton trough is a lower age limit provided by the North Union granite gneiss, the protolith of which intruded the Bucksport and Appleton Ridge formations at $422 \pm 2 \mathrm{Ma}$ (Tucker et al. 2001). For this study, we feel that the maximum depositional age of the Ghent Phyllite $(476 \pm 18 \mathrm{Ma})$, which was calculated from 157 analyzed grains, provides a more robust constraint for rocks of the Fredericton trough in south-central Maine than the maximum age determined for the Appleton Ridge Formation $(489 \pm 16 \mathrm{Ma})$, which is based on only 62 analyses. Ludman et al. (2018) also provide detrital zircon data $(\mathrm{n}=56)$ for an Appleton Ridge sample from south-central Maine and report a "youngest grain cluster" at $\sim 468 \mathrm{Ma}$ (no uncertainty provided) which is consistent with our findings.

\section{Jam Brook Complex (SC-5 and SC-4)}

As discussed previously, the Jam Brook Complex is interpreted to represent a collage of thin stratigraphic units juxtaposed by faults (Berry et al. 2016). Although potential correlatives for some of these individual units have been proposed, there are no direct constraints on the depositional ages of any of the units within the fault complex. The wildly disparate maximum depositional ages of $440 \pm 13 \mathrm{Ma}$ and $975 \pm 64 \mathrm{Ma}$ determined for the two Jam Brook Complex samples analyzed in this study appear to confirm the structural mélange interpretation. As discussed in more detail below, this analysis of Jam Brook Complex detrital zircon indicates that the complex may contain some of the oldest rocks in the state of Maine.

\section{Hart Neck Formation (SC-1)}

The Hart Neck Formation of the Benner Hill Sequence contains deformed Caradocian brachiopods (Boucot et al. 1972) and using the detailed timescale of Cooper and Sadler (2012), deposition is constrained to the time interval between 458-448 Ma. The two youngest detrital zircon ages determined from this sample (410 and $302 \mathrm{Ma}$ ) are clearly anomalously young and likely reflect the effects of postcrystallization $\mathrm{Pb}$-loss. The next youngest individual age is $466 \pm 24 \mathrm{Ma}$ and serves as our preferred maximum depositional age given that the age provided by the method of 
Dickinson and Gehrels (2009) is significantly o lder (501 \pm $12 \mathrm{Ma}$ ) than the known depositional age based on preserved fossils.

\section{Detrital zircon provenance}

One of the more powerful interpretive tools made possible by detrital zircon geochronology is the determination of sediment provenance (e.g., Gehrels et al. 2011). By linking detrital zircon populations found in samples of sedimentary rock to known sources of igneous zircon, these interpretations can indicate the location of initial sedimentary deposition relative to sources of detrital zircon. The basis of detrital zircon provenance interpretation is the fact that for a given depositional setting, detrital zircon could be sourced from any number of different surrounding landmasses (e.g., continents and island arcs) with unique tectonic histories which introduced zircon into the sediment cycle at varying rates over time (Gehrels 2014). By matching the distribution of detrital zircon ages from a sample (i.e., peaks at particular ages) to known periods of magmatism in potential sources, a link is drawn between the crystallization of zircon in a particular region and its deposition as detrital zircon in an adjacent sedimentary basin (Thomas 2011).

Lithostratigraphic belts preserved in the south-central Maine portion of the northern Appalachians (Fig. 2) initially formed in the Iapetus and Rheic Oceans before being accreted to the Laurentian margin during Silurian-Devonian orogenesis (e.g., van Staal et al. 2012; van Staal and Barr 2012; Domeier 2016). Sedimentary basins in these oceans were surrounded by a number of potential sources of detrital zircon including the large continental landmasses of Laurentia and Gondwana, smaller Gondwana-derived continental landmasses (e.g., Ganderia, Avalonia, Meguma), and numerous evolving early Paleozoic volcanic arc terranes (e.g., Penobscot and Popelogan-Victoria arc terranes). Waldron et al. (2018) recently summarized many of the firstorder differences between detrital zircon populations derived from these different sources. These major differences include: (1) Laurentian sources are characterized by high concentrations of detrital zircons between 900 and $1100 \mathrm{Ma}$, with a broad range of much less abundant Mesoproterozoic and Paleoproterozoic zircons (i.e., subdued peaks in an age distribution); (2) Gondwana-derived sources (including Ganderian basement), although variable depending on the specifics of origin (e.g., Ganderia versus A valonia), have large concentrations of zircon in the 540 to $650 \mathrm{Ma}$ age range, generally lack 900 to $1100 \mathrm{Ma}$ zircons, and many samples have zircons in the 1900 to $2200 \mathrm{Ma}$ age range; and (3) intra-oceanic volcanic arc terranes contain zircon populations corresponding to the time of volcanism in the arcs (e.g., 515-485 Ma for Penobscottian arcs and 475-455 Ma for Popelogan-Victoria arc terranes).

\section{Lithotectonic belts exhibiting Gondwanan signatures}

Zircon geochronology results from the Benner Hill Se- quence (SC-1), Fredericton trough (SC-6 and SC-7), and the Casco Bay Group (SC-8) indicate strong Gondwanan affinities for rocks in these terranes (Figs. 5b-e). Each age distribution displays prominent peaks between 540 to $600 \mathrm{Ma}$, a lack of zircons in the 900 to $1100 \mathrm{Ma}$ age range, and less prominent older peaks that correlate well with known signatures of Gondwana-derived sediment (Pollock et al. 2007; Waldron et al. 2018).

The zircon age population derived from sample SC-1 of the Hart Neck Formation of the Benner Hill Sequence (Fig. 5e) displays a very pronounced peak at $\sim 540 \mathrm{Ma}$ with much smaller secondary peaks at $\sim 1470 \mathrm{Ma}$ and $\sim 1960 \mathrm{Ma}$. Though the distinction is not definitive, ages between 600-650 Ma are thought to be typical of Avalonian sources while ages around $550 \mathrm{Ma}$ are more indicative of Ganderian detritus (Waldron et al. 2018), suggesting the distribution observed from our Benner Hill sample represents material primarily sourced from Ganderia as opposed to Avalonia.

Our two samples from the Fredericton trough in south-central Maine (SC-6 and SC-7, Figs. 5c-d) are remarkably similar with pronounced peaks at $550 \mathrm{Ma}$, very few zircon grains in the 900 to $1100 \mathrm{Ma}$ age range, and several small secondary peaks in the Mesoproterozoic and Paleoproterozoic. These findings are very similar to those reported by Dokken et al. (2018) for the early Llandovery Digdeguash Formation in the Fredericton trough in southern New Brunswick, a potential Appleton Ridge Formation correlative. Dokken et al. (2018) showed that younger Fredericton trough strata (e.g., Flume Ridge Formation) from this region exhibit a $\sim 1000$ Ma peak suggestive of later Laurentian input into the Fredericton trough. Comparisons of our results with those of Dokken et al. (2018) suggest that both the Appleton Ridge Formation and Ghent Phyllite in south-central Maine represent the early stages of Fredericton trough sediment fill that lacks a Laurentian input.

Ludman et al. (2018) presented detrital zircon data from a different Appleton Ridge sample and their results are notably different from what we have presented here for sample SC-6. Specifically, the Ludman et al. (2018) Appleton Ridge age spectrum reveals a significant $\sim 1000$ Ma peak that is not present in our Appleton Ridge sample, or our Ghent Phyllite sample from the same belt (see Fig. 5). It should be noted that both the Ludman et al. $(2018)(\mathrm{n}=56)$ and our $(\mathrm{n}=62)$ Appleton Ridge samples contain less than an optimal number of grains needed to reveal the main age groupings within an individual sample (Vermeesch 2004 suggested that at least 117 grains are needed). Therefore, additional sampling and a more robust number of analyses within individual samples will be required to resolve the provenance complexities within the Fredericton Trough that are suggested from recent studies (Dokken et al. 2018; Ludman et al. 2018).

Our sample from the Ordovician Cape Elizabeth Formation of the Casco Bay Group (Fig. 5b) displays a pronounced $\sim 600 \mathrm{Ma}$ peak in addition to a series of older peaks often associated with Amazonian signatures (Pollock et al. 2007; Waldron et al. 2018). West et al. (2008) reported a similar late Neoproterozoic detrital zircon peak from the underlying 
Cushing Formation of the Casco Bay Group. Additionally, based on trace element and $\mathrm{Nd}$ isotopic signatures, West et al. (2003) suggested that volcanic rocks of the overlying Spring Point Formation of the Casco Bay Group were generated through partial melting of Gondwana-derived crustal material. Thus, all available evidence from rocks of the Casco Bay Group is consistent with Gondwanan affinity.

\section{Lithotectonic belts exhibiting a Laurentian signature}

Unlike the clear Gondwanan distributions of detrital zircon ages described in the previous section, zircons from the Vassalboro Group (SC-9, Fig. 5a) indicate a different provenance for the rocks now exposed on the eastern structural margin of the Central Maine basin. The age distribution for SC-9 does not show the prominent $~ 540-650$ Ma peak associated with source terranes of Gondwanan affinity, but rather a high density of Neoproterozoic grains (peaks at $\sim 1080 \mathrm{Ma}$ and $\sim 1560 \mathrm{Ma}$ ) that match well with Laurentian origin (Pollock et al. 2007; Waldron et al. 2018). Meanwhile, the smaller but prominent $\sim 460$ Ma peak suggests an additional source of detritus derived from a Middle to Late Ordovician volcanic arc terrane, possibly the Ordovician arc volcanic rocks of the Falmouth-Brunswick Group or Casco Bay Group in the Liberty-Orrington belt which are exposed immediately to the east of the Central Maine belt (Fig. 2). Thus, our data from the easternmost portion of the Central Maine basin suggest that these Silurian sedimentary rocks had input from a Laurentian source supplemented with detritus from an actively eroding Ordovician arc. These findings are similar to those determined for more westerly portions of the Central Maine basin where sediments also exhibit Laurentian and early Paleozoic detrital input (Bradley and O'Sullivan 2017). Ludman et al. (2018) provided an alternative hypothesis and suggested that sediment input into the Central Maine Basin was from recycled Ganderian basement sources, with little input from external terranes (e.g., Laurentia or Avalonia).

\section{The Jam Brook Complex}

The Jam Brook Complex has been interpreted to represent a structural complex that contains a variety of thin units juxtaposed along faults (Berry et al. 2016). This interpretation is supported by the radically different detrital zircon age populations obtained from the two samples collected from the complex (SC-4 and SC-5, Figs. 5f-g). The distribution of SC-4 detrital zircon (Fig. $5 \mathrm{~g}$ ) is dominated by a pronounced narrow peak centered on $\sim 470 \mathrm{Ma}$ with only two outlying older grains. The result strongly suggests a very restricted source of Ordovician detritus for the sedimentary protolith, such as an actively eroding Ordovician volcanic arc terrane. In stark contrast, sample SC-5 displays a broad distribution of Mesoproterozoic ages with two peaks at $\sim 1270 \mathrm{Ma}$ and $\sim 1550 \mathrm{Ma}$ (Fig. 5f). These peaks do not match well with Laurentian signatures (e.g., no 900-1100 Ma peak), but rather are more similar to those found in the West
African craton (e.g., Assabet of Bradley et al. 2015). This association is tentative, but what is clear from our Jam Brook Complex findings is that the strata contained in the complex have widely varying origins.

\section{Tectonic environments of deposition}

An additional interpretive method applied to detrital zircon geochronology is the determination of the tectonic setting of sediment deposition. Similar to the interpretation of sediment provenance, the technique works by exploiting known signatures in zircon age distributions. However, rather than reflecting particular events in the geologic record, the signatures used in this method result from different sets of conditions unique to each tectonic regime which affect how detrital zircon is introduced into the sediment cycle. These differences are primarily controlled by two factors: the volume and preservation potential of zircon-producing magma generated in the system, and the degree to which that magmatic material is available for erosion of detrital zircon (Cawood et al. 2012). For example, a basin developed on a convergent plate boundary (e.g., a forearc or backarc basin) is likely to receive zircon that crystallized relatively recently during arc volcanism, resulting in a small difference between the age of deposition and the crystallization age of detrital zircons. In contrast, a basin in a collisional regime (e.g., a foreland basin) is more likely to receive detrital zircon eroded from relatively old intrusive igneous bodies that only recently reached the surface, resulting in a pronounced difference between the timing of zircon crystallization and deposition.

These differences in crystallization ages and depositional ages can be observed in probability density distributions. For instance, the narrow, isolated peak in the age distribution from SC-4 (Fig. 5f) represents a small difference between these ages and is suggestive of sedimentary deposition in a convergent regime proximal to active zircon-producing felsic to intermediate magmatism. However, as demonstrated by Cawood et al. (2012), this metric is best visualized by a cumulative proportion curve (CPC) that shows which percentages of the analyzed zircon population correspond to particular differences between crystallization and sedimentation age. These authors compiled detrital zircon data from a number of different types of basins within three endmember tectonic settings and plotted the corresponding CPCs to identify signatures that could link other zircon age distributions to potential tectonic environments (Fig. 6a). There is overlap in the generalized regions of the plot occupied by the CPCs of each of these endmembers, but gaps between them provide two percentage thresholds at which tectonic designations can be assigned. If the difference between crystallization age and depositional age (CA-DA) is $>150 \mathrm{Ma}$ in $5 \%$ of the sample, this indicates an extensional setting (labeled " $\mathrm{C}$ " in Fig. 6a). If CA-DA is $<100 \mathrm{Ma}$ in $30 \%$ of the sample, a convergent regime is assigned (labeled " $A$ " in Fig. $6 a)$. If $30 \%$ of the sample has a CA-DA $>100 \mathrm{Ma}$, it is given a collisional setting designation (labeled "B" in Fig. 6a). 


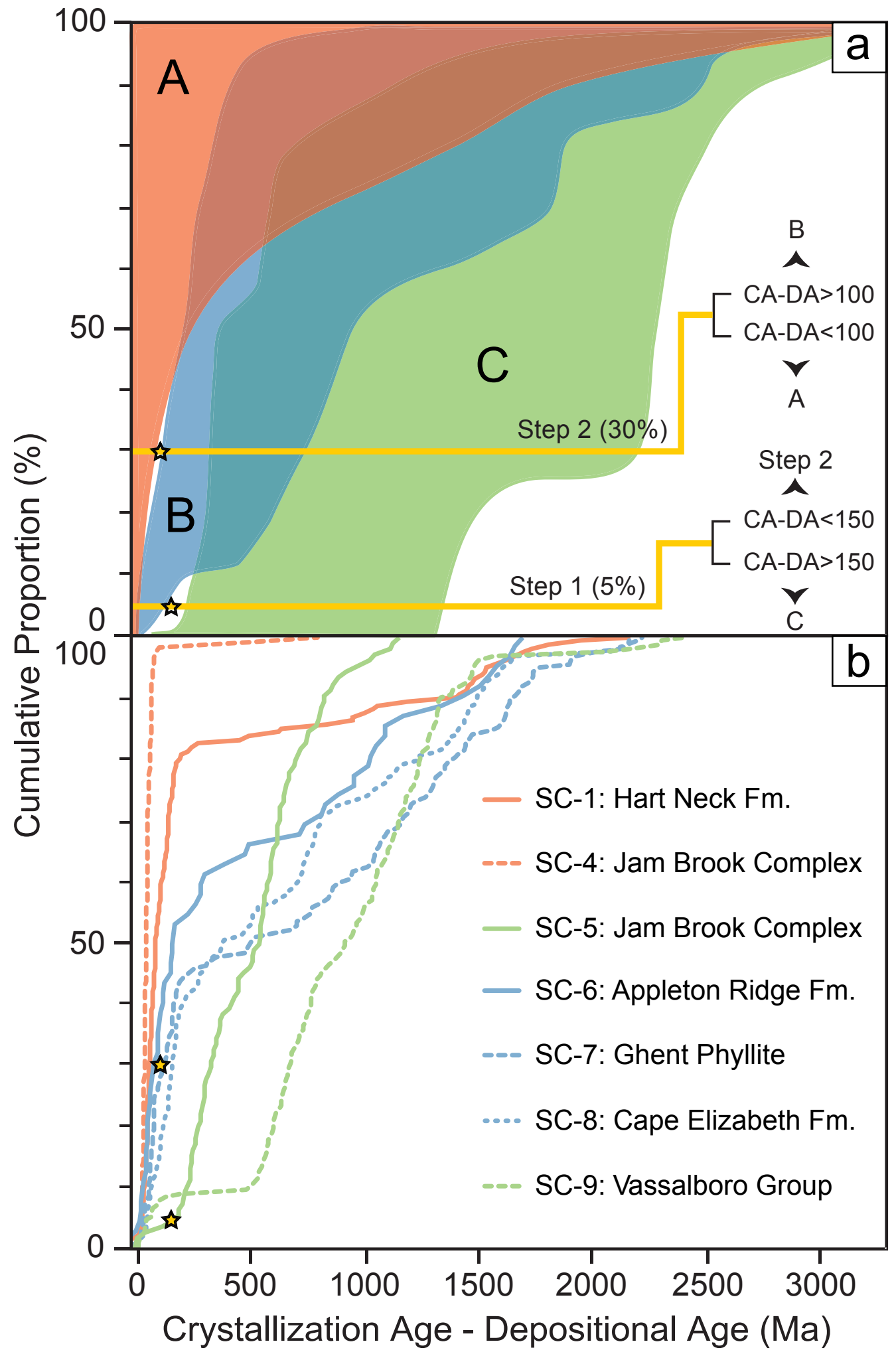

Figure 6. Tectonic settings of sediment deposition as indicated by the delay between original crystallization and subsequent deposition of detrital zircon. (a) Cawood et al. (2012) summary of fields for convergent (A, orange), collisional (B, blue), and extensional ( $C$, green) basins. These fields are based on the difference between measured crystallization ages (CA) of detrital zircon and the estimated depositional ages (DA) of the samples from which they were sourced, plotted as cumulative proportion curves and grouped based on known depositional settings. Annotations show the thresholding scheme used for the determination of tectonic setting for samples of unknown origin; see Cawood et al. (2012, Fig. 3) for details. (b) Cumulative proportion curves of samples analyzed in this study, color-coded by the tectonic setting indicated by Cawood et al. (2012) thresholds (yellow stars) and/or overall distribution shape. See text for details. 
Figure $6 \mathrm{~b}$ presents a compilation of cumulative proportion curves associated with the detrital zircon age distributions of each sample analyzed in this study. In comparing these curves to the signature thresholds of endmember tectonic settings provided by Cawood et al. (2012) in Figure $6 \mathrm{a}$, the following assignments can be made: (1) convergent settings are clearly exemplified by samples SC- 1 and SC- 4 from the Hart Neck Formation and Jam Brook Complex, respectively; (2) sample SC-5 of the Jam Brook Complex shows an extensional setting; and (3) collisional settings are displayed by samples from the Ghent Phyllite of the Fredericton trough (SC-7) and Cape Elizabeth Formation of the Casco Bay Group (SC-8).

Tectonic settings for the remaining two samples are less clear as there is a difference between the settings indicated by their ages at the $5 \%$ and $30 \%$ thresholds and the settings indicated by the overall shape of their respective CPCs. The Appleton Ridge Formation sample from the Fredericton trough (SC-6) has CA-DA $<100 \mathrm{Ma}$ in $30 \%$ of zircon grains suggesting a convergent setting, but the extent of its CPC fits better with a collisional setting. Similarly, the CPC for the Vassalboro Group sample from the Central Maine basin (SC-9) fails to meet the CA-DA $>150$ Ma threshold in $5 \%$ of grains but otherwise appears most similar to an extensional setting. This general designation is consistent with previous tectonic interpretations of the Central Maine basin (Bradley et al. 2000; Bradley and O'Sullivan 2017), although details remain unresolved (e.g., whether this extensive basin was floored by oceanic lithosphere). The ambiguous nature of these two CPCs is likely due to a combination of non-ideal sample characteristics (i.e., low n-value in SC-6 and dual sediment sources in SC-9).

\section{Regional tectonic significance}

The previously presented interpretations of depositional age, sediment provenance, and tectonic setting are summarized in Table 3 and provide key insights into the origins of the different lithotectonic belts currently juxtaposed in south-central Maine. These insights demonstrate that the bedrock geology preserved in this region resulted from the accretion of multiple terranes containing sedimentary rocks that formed in a variety of basins proximal to several distinct sediment sources over the course of hundreds of millions of years. Pre-Silurian rocks (Casco Bay Group, Benner Hill Sequence, Jam Brook Complex) show no significant evidence of Laurentian-derived detritus, and our samples from what one might presume to be the lower portions of the Fredericton trough also show no evidence of Laurentian input (this presumption is based on comparisons with the findings of Dokken et al. 2018). In contrast, Silurian rocks from the eastern margin of the Central Maine basin have zircon populations suggestive of Laurentian input, similar to findings in the western portions of this same basin (Bradley et al. 2015), and the younger portions (post-Llandovery) of the Fredericton trough (Dokken et al. 2018). These findings support the hypothesis that a barrier existed between the Laurentian margin and Gondwana-derived terranes prior to about $435 \mathrm{Ma}$ (Dokken et al. 2018). Alternatively, Ludman et al. (2018) suggested that little sediment input into the Central Maine basin or Fredericton trough was derived from Laurentian or Avalonian sources, but rather was largely derived from Ganderian basement that became emergent following Late Ordovician orogenesis. Clearly additional detailed sediment provenance studies in the thick, largely post-Ordovician sedimentary basins in the northern Appalachians (e.g., Connecticut Valley, Central Maine/ Aroostook-Matapedia, Fredericton) are needed to fully understand the sediment sources of these basins, the pathways for sediment transport into them, and ultimately, SilurianEarly Devonian paleogeography.

\section{CONCLUSIONS}

New detrital zircon ages from metasedimentary rocks of the eastern structural margin of the Central Maine basin, Liberty-Orrington belt, Fredericton trough, Jam Brook Complex, and Benner Hill Sequence in south-central Maine reveal the following:

Table 3. Summary of Interpretative Findings.

\begin{tabular}{cccccc}
\hline Sample & Lithotectonic Belt & Formation/Unit & $\begin{array}{c}\text { Maximum } \\
\text { Age (Ma) }\end{array}$ & Affinity* & $\begin{array}{c}\text { Tectonic } \\
\text { Setting }\end{array}$ \\
\hline SC-9 & Central Maine & Vassalboro Group & $422 \pm 20$ & L,V & Extensional \\
SC-8 & Liberty-Orrington & Cape Elizabeth Fm. & $478 \pm 20$ & G & Collisional \\
SC-7 & Fredericton & Ghent Phyllite & $476 \pm 18$ & G & Collisional \\
SC-6 & Fredericton & Appleton Ridge Fm. & $489 \pm 16$ & G & Collisional \\
SC-5 & Jam Brook & Jam Brook & $975 \pm 64$ & WA & Extensional \\
SC-4 & Jam Brook & Jam Brook & $440 \pm 13$ & V & Convergent \\
SC-1 & Benner Hill & Hart Neck Fm. & $466 \pm 24$ & G & Convergent \\
\hline
\end{tabular}

${ }^{\star} \mathrm{G}=$ Gondwanan affinity, $\mathrm{V}=$ early Paleozoic volcanic arc, $\mathrm{L}=$ Laurentian, WA $=$ West Africa 
1. Detrial zircon ages from the Silurian Vassalboro Group along the eastern structural margin of the Central Maine basin indicate sediment input from both Ordovician volcanic arc terrane and Laurentian sources and deposition in an extensional setting.

2. Results from Ordovician rocks of the Casco Bay Group in the Liberty-Orrington belt which indicate detritus derived from terranes of a Gondwanan origin are supportive of previous findings (West et al. 2003, 2008).

3. Detrital zircon from the Appleton Ridge Formation and Ghent Phyllite of the Fredericton trough are consistent with a sediment source of Gondwanan affinity and we find no evidence of Laurentian sediment input in these rocks. These findings are consistent with that of Dokken et al. (2018) for older Fredericton trough strata (i.e., Digdeguash Formation) east of the Fredericton fault in southern New Brunswick, but differ from those of Ludman et al. (2018).

4. Two samples from the Jam Brook Complex show extreme differences in depositional age and tectonic affinity, and support the Berry et al. (2016) hypothesis that rocks of the Jam Brook Complex represent a structural complex rather than a single stratigraphic unit. Detrital zircon from one sample suggests a West African sediment source and deposition in the late Mesoproterozoic or earliest Neoproterozoic while the other displays evidence for direct deposition proximal to an eroding Ordovician volcanic arc terrane.

5. Detrital zircon from Ordovician rocks of the Benner Hill Sequence indicate a sediment source of Gondwanan affinity with no Laurentian input.

6. Collectively, pre-Silurian rocks and strata from the Appleton Ridge Formation and Ghent Phyllite in the Fredericton trough show no evidence of Laurentian sediment input, suggesting that a barrier to this sediment input existed between the Laurentian margin and Gondwana-derived sediment sources (e.g., Ganderian terranes) prior to about $435 \mathrm{Ma}$.

\section{ACKNOWLEDGEMENTS}

Funding for this work was provided by the Maine Geological Survey through the STATEMAP program, and by the Middlebury College Geology Department. We thank Atticus Proctor for assistance in the field, Kristina Walowski for sharing sample preparation techniques and laboratory equipment, and Jody Smith and Ray Coish for help with $\mathrm{U}-\mathrm{Pb}$ data acquisition. DPW is indebted to Henry Berry of the Maine Geological Survey for many discussions over the years of the geology of this region, and in particular his more recent thoughts concerning the complexities of the Jam Brook Complex. The authors sincerely thank Paul Karabinos and Allan Ludman for their thorough reviews of the initial manuscript.

\section{REFERENCES}

Berry, H.N. IV and Osberg, P.H. 1989. A stratigraphic syn- thesis of eastern Maine and western New Brunswick. In Studies in Maine Geology. vol. 2. Edited by R.D. Tucker and R.G. Marvinney. Maine Geological Survey, Augusta, Maine, pp. 1-29.

Berry, H.N. IV, Schoonmaker, A., and Guidotti, C.V. 2000. The Benner Hill sequence. In Guidebook for field trips in coastal and east-central Maine. $92^{\text {nd }}$ New England Intercollegiate Geological Conference Guidebook. Edited by M.G. Yates, D.R. Lux, and J.T. Kelley. pp. 187-207.

Berry, H.N. IV, West, D.P., Jr., and Burke, W. 2016. Bedrock relationships along the Sennebec Pond fault: A structural puzzle, a stratigraphic enigma, and a tectonic riddle. In Guidebook for Field Trips along the Maine Coast from Maquoit Bay to Muscongus Bay. $108^{\text {th }}$ New England Intercollegiate Geological Conference Guidebook, Edited by H.N. Berry IV and D.P. West, Jr. pp. 43-70.

Bickel, C. E. 1976. Stratigraphy of the Belfast quadrangle, Maine. In Contributions to the stratigraphy of New England. Edited by L.R. Page. Geological Society of America Memoir 148, pp. 97-128. https://doi.org/10.1130/ MEM148-p97

Black, L. P., Kamo, S. L., Allen, C. M., Davis, D. W., Aleinikoff, J. N., Valley, J. W., Mundil, R., Campbell, I. H., Korsch, R. J., Williams, I. S., Foudoulis, C. 2004. Improved ${ }^{206} \mathrm{~Pb} /{ }^{238} \mathrm{U}$ microprobe geochronology by the monitoring of a trace-element-related matrix effect; SHRIMP, ID-TIMS, ELA-ICP-MS and oxygen isotope documentation for a series of zircon standards. Chemical Geology, 205, pp. 115-140. https://doi.org/10.1016/j.chemgeo.2004.01.003

Boucot, A. J., Brookins, D., Forbes, W., and Guidotti, C. V. 1972. Staurolite zone Caradoc (Middle-Late Ordovician) age, Old World Province brachiopods from Penobscot Bay, Maine: Geological Society of America, Bulletin, 83, pp. 1953-1960. https://doi.org/10.1130/0016-7606(1972) 83[1953:SZCMOA]2.0.CO;2

Bradley, D. C. and O'Sullivan, P. 2017. Detrital zircon geochronology of pre- and syncollisional strata, Acadian orogen, Maine Appalachians. Basin Research, 29, pp. 571590. https://doi.org/10.1111/bre.12188

Bradley, D.C., Tucker, R.D., Lux, D.R., Harris, A.G., and McGregor, D.C. 2000. Migration of the Acadian orogeny and foreland basin across the northern Appalachians of Maine and adjacent areas. United States Geological Survey Professional Paper 1624, 49 p.

Bradley, D.C., O'Sullivan, P., Cosca, M.A., Motts, H.A., Horton, J.D., Taylor, C.D., Beaudoin, G., Lee, G.K., Ramezani, J., Bradley, D.B., Jones, J.V., and Bowring, S. 2015. Synthesis of geological, structural, and geochronological data. In Second projet de renforcement institutional de secteur minier de la République Islamique de Mauritanie (PRISM-II). Edited by C.D. Taylor. United States Geological Survey Open-File Report 2013-1280-A, 328 p. [In English and French].

Burke, W.B. 2016. Petrology, geochemistry, and U-Pb zircon ages of metamorphosed Cambrian-Ordovician volcanic rocks of the St. Croix Belt, western Penobscot Bay, Maine. Unpublished Middlebury College Thesis, Middle- 
bury, Vermont, $109 \mathrm{p}$.

Cartwright, S.F.A. 2018. Detrital zircon geochronology of strata from multiple accreted terranes in south-central Maine. Unpublished Middlebury College thesis, Middlebury, Vermont, $145 \mathrm{p}$.

Cawood, P.A., Hawkesworth, C.J., and Dhuime, B. 2012. Detrital zircon record and tectonic setting. Geology, 113, pp. 1234-1246.

Cooper, R.A. and Sadler, P.M. 2012. The Ordovician Period. In The geologic time scale 2012. Edited by F.M. Gradstein, J.G. Ogg, M.D. Schmitz, and G.M. Ogg. Elsevier Publishers, pp. 489-423. https://doi.org/10.1016/B978-0-44459425-9.00020-2

Dickinson, W. and Gehrels, G. 2009. Use of U-Pb ages of detrital zircons to infer maximum depositional ages of strata: A test against a Colorado Plateau Mesozoic database. Earth and Planetary Science Letters, 288, pp. 115-125. https://doi.org/10.1016/j.epsl.2009.09.013

Dokken, R,J, Waldron, J.W.F., and Dufrane, S.A. 2018. Detrital zircon geochronology of the Fredericton trough, New Brunswick, Canada: Constraints on the Silurian closure of remnant Iapetus Ocean. American Journal of Science, 318, pp. 684-725. https://doi.org/10.2475/06.2018.03

Domeier, M. 2016. A plate tectonic scenario for the Iapetus and Rheic Oceans. Gondwana Research, 36, pp. 275-295. https://doi.org/10.1016/j.gr.2015.08.003

Fyffe, L. and Riva, J. 1990. Revised stratigraphy of the Cookson Group of southwestern New Brunswick and adjacent Maine. Atlantic Geology, 26, pp. 271-276. https://doi. org/10.4138/1709

Fyffe, L.R., Johnson, S.C., and van Staal, C.R. 2011. A review of Proterozoic to early Paleozoic lithotectonic terranes in the northeastern Appalachian orogeny of New Brunswick Canada, and their tectonic evolution during Penobscot, Taconic, Salinic, and Acadian orogenesis. Atlantic Geology, 47, pp. 211-248. https://doi.org/10.4138/ atlgeol.2011.010

Gehrels, G. 2014. Detrital zircon U-Pb geochronology applied to tectonics. Annual Review of Earth and Planetary Sciences, 42, pp. 127-149. https://doi.org/10.1146/annurev-earth-050212-124012

Gehrels, G. 2018. Zircon Standards Table [Chart]. From Arizona Laserchron Center. URL <https://drive.google. com/file/d/1BHwKmBbkg 8iyWM-Ht3qFJ1hz1cjfU2a/ view>, 14 January 2019.

Gehrels, G. E., Blakey, R., Karlstrom, K. E., Timmons, J. M., Dickinson, B., and Pecha, M. 2011. Detrital zircon U-Pb geochronology of Paleozoic strata in the Grand Canyon, Arizona. Lithosphere, 3, pp. 183-200. https://doi. org/10.1130/L121.1

Gerbi, C. and West, D.P., Jr. 2007. Use of U-Pb geochronology to identify successive, spatially overlapping tectonic episodes during Silurian-Devonian orogenesis in south-central Maine, USA. Geological Society of America Bulletin, 119, pp. 1218-1231. https://doi.org/10.1130/ B26162.1

Horstwood, M.S.A., Kosler, J., Gehrels, G., Jackson, S.E.,
McLean, N.M., Paton, C., Pearson, N.J., Sircombe, K., Slyvester, P., Vermeesch, P., Bowring, J.F., Condon, D.J., and Schoene, B. 2016. Community-derived standards for LA-ICP-MS U-(Th-) Pb geochronology - Uncertainty propagation, age interpretation, and data reporting. Geostandards and Geoanalytical Research, 40, pp. 311-332. https://doi.org/10.1111/j.1751-908X.2016.00379.x

Hussey, A.M., II, Bothner, W.A., and Aleinikoff, J. 2010. The tectono-stratigraphic framework and evolution of southwestern Maine and southeastern New Hampshire, In From Rodinia to Pangea: The Lithotectonic Record of the Appalachian Region. Edited by R.P. Tollo, M.J. Bartholomew, J.P. Hibbard, and P.M. Karabinos. Geological Society of America Memoir 206, pp. 205-230. https://doi. org/10.1130/2010.1206(10)

Karabinos, P., Macdonald, F.A., and Crowley, J.L. 2017. Bridging the gap between the foreland and hinterland I: Geochronology and plate tectonic geometry of Ordovician magmatism and terrane accretion on the Laurentian margin of New England. American Journal of Science, 317, pp. 515-554. https://doi.org/10.2475/05.2017.01

Klepeis, K. A., Crawford, M. L., and Gehrels, G. 1998. Structural history of the crustal-scale Coast shear zone north of Portland Canal, southeast Alaska and British Columbia. Journal of Structural Geology, 20, pp. 883-904. https:// doi.org/10.1016/S0191-8141(98)00020-0

Kuiper, Y.D., Thompson, M.D., Barr, S.M., White, C.E., Hepburn, J.C., and Crowley, J.L. 2017. Detrital zircon evidence for Paleoproterozoic West African crust along the eastern North American continental margin, Georges Bank, offshore Massachusetts, USA. Geology, 45, pp. 811-814. https://doi.org/10.1130/G39203.1

Ludman, A. 1987. Pre-Silurian stratigraphy and tectonic significance of the St. Croix Belt, southeastern Maine. Canadian Journal of Earth Sciences, 24, pp. 2459-2469. https://doi.org/10.1139/e87-230

Ludman, A., Aleinikoff, J., Berry, H.N. IV, and Hopeck, J.T. in 2018. U-Pb zircon SHRIMP evidence for age and provenance of Early Paleozoic rocks on the Ganderian Plate, east-central Maine. Atlantic Geology, 54, pp. 335-387. https://doi.org/10.4138/atlgeol.2018.013

Ludwig, K.R. 2012. Isoplot: A geochronological toolkit for Microsoft Excel: Berkeley Geochronology Center Special Publication No. 5, University of California at Berkley. URL <http://www.bgc.org/isoplot etc/isoplot/Isoplot3 75-4 15manual.pdf $>$, 01 June, 2018.

Marvinney, R.G., West, D.P., Jr., Grover, T.W., and Berry, H.N. IV. 2010. A stratigraphic review of the Vassalboro Group in a portion of central Maine. In Guidebook for Field Trips in Coastal and Interior Maine, $102^{\text {nd }}$ New England Intercollegiate Geological Conference Guidebook. Edited by C. Gerbi, M. Yates, and D. Lux. pp. 61-76.

McKerrow, W. S. and Ziegler, A. M. 1971. The lower Silurian paleogeography of New Brunswick and adjacent areas: Journal of Geology, 79, pp. 635-646. https://doi. org/10.1086/627695

Melchin, M.J., Sadler, P.M., and Cramer, B.D. 2012. The Si- 
lurian Period. In The geologic time scale 2012. Edited by F.M. Gradstein, J.G. Ogg, M.D. Schmitz, and G.M. Ogg. Elsevier Publishers, pp. 525-558. https://doi.org/10.1016/ B978-0-444-59425-9.00021-4

Osberg, P.H. 1988. Geologic relations within the shalewacke sequence in south-central Maine. In Studies in Maine Geology: Structure and Stratigraphy. Edited by R.D. Tucker, R.D. and R.G. Marvinney. Maine Geological Survey, 1, pp. 51-73.

Osberg, P.H. and Guidotti, C.V. 1974. The geology of the Camden-Rockland area. In Guidebook for field trips in east-central and north-central Maine. Edited by P.H. Osberg. New England Intercollegiate Guidebook, pp. 48-60.

Orr, P. and Pickerill, R., 1995, Trace fossils from Early Silurian flysch of the Waterville Formation, Maine, USA. Northeastern Geology and Environmental Sciences, 17, pp. 394-414.

Pankiwskyj, K., Ludman, A., Griffin, J., and Berry, W. 1976. Stratigraphic relationships on the southeast limb of the Merrimack Synclinorium in central and west-central Maine. In Studies in New England Geology. Edited by A. Brownlow and P. Lyons. Geological Society of America Memoir 146, pp. 263-280.

Pollock, J. C., Wilton, D. H. C., van Staal, C. R., and Morrissey, K. D. 2007. U-Pb detrital zircon geochronological constraints on the Early Silurian collision of Ganderia and Laurentia along the Dog Bay Line: The terminal Iapetan suture in the Newfoundland Appalachians. American Journal of Science, 307, pp. 399-433. https://doi. org $/ 10.2475 / 02.2007 .04$

Reusch, D.N., Holm-Denoma, C.S., and Slack, J.F. 2018. $\mathrm{U}-\mathrm{Pb}$ zircon geochronology of Proterozoic and Paleozoic rocks, North Islesboro, coastal Maine (USA): links to West Africa and Penobscottian orogenesis in southeastern Ganderia? Atlantic Geology, 54, pp. 189-224. https:// doi.org/10.4138/atlgeol.2018.008

Robinson, P., Tucker, R.D., Bradley, D., Berry, H.N., IV, and Osberg, P.H. 1998, Paleozoic orogens in New England, USA. GFF, Geological Society of Sweden, 120, pp. 119148.

Sláma, J., Košler, J., Condon, D. J., Crowley, J. L., Gerdes, A., Hanchar, J. M., Whitehouse, M. J. 2008. Plešovice zircon - A new natural reference material for $\mathrm{U}-\mathrm{Pb}$ and $\mathrm{Hf}$ isotopic microanalysis. Chemical Geology, 249, pp. 1-35. https://doi.org/10.1016/j.chemgeo.2007.11.005

Thomas, W. A. 2011. Detrital-zircon geochronology and sedimentary provenance. Lithosphere, 3, pp. 304-308. https://doi.org/10.1130/RF.L001.1

Tucker, R.D., Osberg, P.H., and Berry, H.N., IV. 2001. The geology of a part of Acadia and the nature of the Acadian Orogeny across central and eastern Maine. American Journal of Science, 301, pp. 205-260. https://doi. org/10.2475/ajs.301.3.205

Van Staal, C.R. and Barr, S.M. 2012. Lithospheric architecture and tectonic evolution of the Canadian Appalachians and associated Atlantic margin. In Tectonic Styles in Canada: the LITHOPROBE Perspective. Edited by J.A.
Percival, F.A. Cook, and R.M. Clowes. Geological Association of Canada, Special Papers, 49, pp. 41-95.

Van Staal, C., Whalen, J., Valverde-Vaquero, P., Zagorevski, A., and Rogers, N. 2009. Pre-Carboniferous, episodic accretion-related, orogenesis along the Laurentian margin of the Northern Appalachians. In Ancient orogens and modern analogues. Edited by B. Murphy, D. Keppie, and A. Hynes. Geological Society of London, Special Publications, 327, pp. 271-316. https://doi.org/10.1144/SP327.13

Van Staal, C.R., Barr, S.M., and Murphy, J.B. 2012. Provenance and tectonic evolution of Ganderia: constraints on the evolution of the Iapetus and Rheic oceans. Geology, 40, pp. 987-990. https://doi.org/10.1130/G33302.1

Vermeesch, P. 2004. How many grains are needed for a provenance study? Earth and Planetary Science Letters, 224, pp. 441-451. https://doi.org/10.1016/j.epsl.2004.05.037

Waldron, J. W. F., Schofield, D. I., and Murphy, J. B., 2018, Diachronous Paleozoic accretion of peri-Gondwanan terranes at the Laurentian margin, In Fifty years of the Wilson cycle concept in plate tectonics. Edited by R.W. Wilson, G.A. Houseman, K.J.W. McCaffrey, A.G. Dore', and S.J.H. Buiter. Geological Society of London, Special Publication, 470, online version. https://doi.org/10.1144/ $\underline{\text { SP470.11 }}$

Wiedenbeck, M., Hanchar, J. M., Peck, W. H., Sylvester, P., Valley, J., Whitehouse, M., Kronz, A., Morishita, Y., Nasdala, L., Fiebig, J., Franchi, I., Girard, J., Greenwood, R., Hinton, R., Kita, N., Mason, P., Norman, M., Ogasawara, M., Piccoli, P., Rhede, D., Satoh, H., Schulz-Dobrick, B., Skår, O., Spicuzza, M., Terada, K., Tindle, A., Togashi, S., Vennemann, T., Xie, Q., and Zheng, Y. 2004. Further characterization of the 91500 zircon crystal. Geostandards and Geoanalytical Research, 28, pp. 9-39. https:// doi.org/10.1111/j.1751-908X.2004.tb01041.x

West, D.P., Jr. 1995. The Norumbega fault zone in south-central Maine: A trip through 80 million years of dextral shear deformation. In Guidebook for field trips in southern Maine and adjacent New Hampshire. $87^{\text {th }}$ New England Intercollegiate Geological Conference Guidebook. Edited by A.M. Hussey, II and R.A. Johnston. pp. 125-143.

West, D.P., Jr., Senese, M.P., and Sterrett, J.B. 2000. Structural Geology and tectonics of Silurian-Devonian terrane accretion in south-central Maine. In Guidebook for field trips in coastal and east-central Maine. $92^{\text {nd }} \mathrm{New}$ England Intercollegiate Geological Conference Guidebook. Edited by M.G. Yates, D.R. Lux, and J.T. Kelley. pp. 107-128.

West, D.P., Jr., Beal, H.M., and Grover, T.W. 2003. Silurian deformation and metamorphism of Ordovician arc rocks of the Casco Bay Group, south-central Maine. Canadian Journal of Earth Sciences, 40, pp. 887-905. https://doi. org/10.1139/e03-021

West, D.P., Jr., Coish, R.A., and Tomascak, P.B. 2004. Tectonic setting and regional correlation of Ordovician metavolcanic rocks of the Casco Bay Group, Maine: Evidence from trace element and isotope geochemistry. Geological Magazine, 141, pp. 125-140. https://doi.org/10.1017/ $\underline{\text { S0016756803008562 }}$ 
West, D.P., Jr., Yates, M.G., Gerbi, C., and Barnard, N.Q. 2008. Metamorphosed Ordovician iron- and manganese-rich rocks in south-central Maine: from peri-Gondwanan deposition through Acadian metamorphism. American Mineralogist, 93, pp. 270-283. https://doi.org/10.2138/ am.2008.2592

Editorial responsibility: Sandra M. Barr

\section{APPENDIX A}

\section{Sample information}

\section{(Locations in UTM coordinates using datum NAD83/WGS84, Zone 19T)}

\section{Sample SC-1: Hart Neck Formation of the Benner Hill sequence}

UTM: 0487391 4885309. Sample collected from a location approximately $4 \mathrm{~km}$ WNW of Rockland, Maine near the southern end of Bog Road. The sampling location is near Stop 2 of Berry et al. (2000) - being approximately $400 \mathrm{~m}$ north of the Power Line traverse described in Stop 2 of that field trip. The rock collected is a rusty weathering quartzite and several moderately sized blocks of an identical lithology containing deformed brachiopods were found immediately adjacent to the sampled outcrop. This strongly suggests the rock collected correlates with outcrop G described at Stop 2 of Berry et al. (2000) and thus is from the top of the Hart Neck Formation of the Benner Hill Sequence.

\section{Sample SC-4: Jam Brook Complex}

UTM: 04821814904441 . Sample collected from a location approximately $10 \mathrm{~km} \mathrm{NNW}$ of Union, Maine - approximately $150 \mathrm{~m}$ west of Peabody Road. The sampling location is well-documented in "Optional Stop 0" of Berry et al. (2016) and corresponds to "Unit D" in Figure 3 of that field trip guide. The sample was collected from a low outcrop just to the north of the trail (shown in figure 3, of Berry et al. 2016) and consists of a fine-grained, orange-brown weathering, light grey quartzite (see Fig. 3c).

\section{Sample SC-5: Jam Brook Complex}

UTM: 0479797 4901625. Sample collected from a location approximately $6 \mathrm{~km}$ NNW of Union, Maine - approximately 50 m west of Sennebec Road, approximately one km north of the intersection with Gurneytown Road. The sample is from a low woods outcrop and consists of a white quartzite with some rusty weathering breakage surfaces. The sample is from a mappable quartzite unit within the Jam Brook Formation.

\section{Sample SC-6: Appleton Ridge Formation of the Fredericton Trough}

UTM: 0479432 4904863. Sample collected from a location approximately $9 \mathrm{~km}$ SSW of Searsmont, Maine - about $1 \mathrm{~km}$ northwest of Appleton in a blueberry field just east of the Appleton Ridge Road. The sample is from a $25 \mathrm{~cm}$ thick micaeous feldspathic quartzite bed within staurolitebearing schists of the Appleton Ridge Formation (Fig. 3b). Sample is near Stop 8 of West et al. (2000).

\section{Sample SC-7: Ghent Phyllite of the Fredericton Trough}

UTM: 0483349 4908439. Sample collected from a location approximately $4 \mathrm{~km} \mathrm{SSW}$ of Searsmont Maine just east of Rt. 131 at the entrance road to Robbins lumber company (a low road-cut on the north side of the entrance road). Sample is from a $25 \mathrm{~cm}$ thick medium grey color metasiltstone bed within what are otherwise dark grey garnet-bearing phyllites. Sample is from NEIGC Stop 12 of West et al. (2000).

\section{Sample SC-8: Cape Elizabeth Formation of the Casco Bay Group}

UTM: 0472664 4912743. Sample collected from a location approximately $12 \mathrm{~km}$ west of Searsmont, Maine - off the Stickney Road approximately $800 \mathrm{~m}$ south of Lake St. George. The sample is from a low blueberry field exposure approximately $100 \mathrm{~m}$ from Stickney Road. The sample is from a $35 \mathrm{~cm}$ thick light grey quartzite bed within sillimanite-bearing mica schists of the Cape Elizabeth Formation (Fig. 3a). The sample is from near NEIGC Stop 7 of West (1995).

\section{Sample SC-9: Vassalboro Group of the Central Maine sequence}

UTM: 0460627 4917653. Sample collected from a location approximately $1.75 \mathrm{~km}$ west of Palermo, Maine - from a road cut on the north side of Rt. 3 . The sample is from a $15 \mathrm{~cm}$ thick light grey metasiltstone bed within calcareous biotite granofels and calc-silicate granofels of the Vassalboro Group. 
Appendix B. U-Pb Laser ablation-ICP-MS detrital zircon isotopic data.

\begin{tabular}{|c|c|c|c|c|c|c|c|c|c|c|c|c|c|c|c|c|c|c|}
\hline \multirow[b]{2}{*}{$\begin{array}{c}\text { Sample and } \\
\text { analysis number }\end{array}$} & \multicolumn{9}{|c|}{ Isotopic Ratios } & \multicolumn{6}{|c|}{ Final Isotopic Ages (Ma) } & \multirow[b]{2}{*}{ Con. } & \multirow[b]{2}{*}{$\begin{array}{l}\text { Plot } \\
\text { Age }\end{array}$} & \multirow[b]{2}{*}{$2 \sigma$} \\
\hline & ${ }^{207} \mathrm{~Pb} /$ & $2 \sigma$ & $\begin{array}{l}{ }^{206} \mathrm{~Pb} / \\
{ }^{238} \mathrm{U}\end{array}$ & $2 \sigma$ & $\begin{array}{l}{ }^{238} \mathrm{U} / \\
{ }^{206} \mathrm{~Pb}\end{array}$ & $2 \sigma$ & $\begin{array}{l}{ }^{207} \mathrm{~Pb} / \\
{ }^{206} \mathrm{~Pb}\end{array}$ & $2 \sigma$ & EC & ${ }^{207} \mathrm{~Pb} /$ & $2 \sigma^{2}$ & ${ }^{206} \mathrm{~Pb} /$ & $2 \sigma$ & $\begin{array}{l}{ }^{207} \mathrm{~Pb} / \\
{ }^{206} \mathrm{~Pb}\end{array}$ & $2 \sigma$ & & & \\
\hline \multicolumn{19}{|c|}{ Sample SC-1: Hart Neck Formation of the Benner Hill sequence } \\
\hline SC-1- & 0.817 & 0.067 & 1060 & 0130 & 433962 & 1.156995 & 0598 & 0047 & 42367 & 599 & 37 & 643 & 73 & 570 & 160 & 0.07 & 643 & 73 \\
\hline 列 & 3.820 & 0.180 & 0.2720 & 0.0220 & 676471 & 0.297362 & 1038 & 0.0059 & 0.84596 & 1588 & 37 & 1560 & 110 & 1671 & 98 & 0.02 & 1671 & 98 \\
\hline SC-1-Spot-8 & 0.691 & 0.039 & 0.0826 & 0.0057 & 12.106540 & 0.835439 & 0.0604 & 0.0038 & 0.75111 & 530 & 23 & 516 & 33 & 610 & 120 & 0.03 & 516 & 33 \\
\hline SC-1-Spot-9 & 0.820 & 0.033 & 0.0995 & 0.0062 & 10.050250 & 0.626247 & 0.0606 & 0.0027 & 0.71475 & 609 & 19 & 610 & 36 & 605 & 91 & 0.00 & 610 & 36 \\
\hline SC-1-Spot-10 & 0.936 & 0.035 & 0.1068 & 0.0059 & 9.363296 & 0.517261 & 0.0630 & 0.0020 & 0.74857 & 669 & 18 & 653 & 34 & 703 & 70 & 0.02 & 653 & 34 \\
\hline SC-1-Spot-39 & 0.702 & 0.036 & 0.0890 & 0.0053 & 11.235960 & 0.669107 & 0.0588 & 0.0025 & 0.55087 & 537 & 22 & 549 & 31 & 543 & 98 & 0.02 & 549 & 31 \\
\hline SC-1-Spot-40 & 0.734 & 0.036 & 0.0884 & 0.0047 & 11.312220 & 0.601441 & 0.0624 & 0.0032 & 0.57886 & 556 & 21 & 546 & 28 & 700 & 110 & 0.02 & 546 & 28 \\
\hline SC-1-Spot-41 & 0.738 & 0.039 & 0.0890 & 0.0045 & 11.235960 & 0.568110 & 0.0600 & 0.0034 & . & 558 & 23 & 549 & 26 & 570 & 130 & 0.02 & 549 & 26 \\
\hline SC-1-Spot-42 & 0.834 & 0.037 & 0.0971 & 0.0053 & 10.298660 & 0.562131 & 0.0640 & 0.0031 & 0.60882 & 613 & 20 & 596 & 31 & 740 & 100 & 0.03 & 596 & 31 \\
\hline SC-1-Spot-43 & 0.698 & 0.028 & 0.0890 & 0.0047 & 11.235960 & 0.593359 & 0.0601 & 0.0024 & 0.00310 & 536 & 17 & 549 & 28 & 621 & 85 & 0.02 & 49 & 28 \\
\hline SC-1-Spot-44 & 6.950 & 0.270 & 0.3740 & 0.0190 & 2.673797 & 0.178730 & 0.1397 & 0.0058 & 0.45434 & 2127 & 43 & 2041 & 92 & 2210 & 71 & 0.04 & 2210 & 71 \\
\hline SC-1-Spot-45 & 7.780 & 0.340 & 0.4070 & 240 & 457002 & 0.144885 & 1449 & 0.0064 & - & 2197 & 40 & 2210 & 110 & 2288 & 72 & 0.01 & 2288 & 72 \\
\hline SC-1-Spot-46 & 0.848 & 0.033 & 0.1068 & 0.0060 & 9.363296 & 0.526028 & 0.0603 & 0.0027 & 0.74725 & 622 & 18 & 653 & 35 & 597 & 93 & 0.05 & 653 & 35 \\
\hline ot- 47 & 5.490 & 0.190 & 0.3470 & 0.0140 & 881844 & 0.116270 & 0.1161 & 0.0034 & 0.45550 & 1899 & 28 & 1916 & 65 & 1894 & 54 & 0.01 & 1894 & 54 \\
\hline SC-1-Spot-54 & 11.500 & 2.900 & 0.3600 & 0.0330 & 2.777778 & 0.231482 & 0.2240 & 0.0400 & 0.21589 & 2410 & 210 & 1960 & 160 & 2760 & 270 & 0.23 & -- & -- \\
\hline SC-1-Spot-55 & 0.745 & 0.042 & 0.0930 & 0.0056 & 10.752690 & 0.647474 & 0.0586 & 0.0034 & 0.52978 & 566 & 24 & 572 & 33 & 540 & 130 & 0.01 & 572 & 33 \\
\hline SC-1-Spot-56 & 4.370 & 0.230 & 0.2660 & 0.0150 & 3.759398 & 0.211996 & 0.1194 & 0.0048 & 0.15241 & 1695 & 43 & 1515 & 76 & 1962 & 65 & 0.12 & 1962 & 65 \\
\hline SC-1-Spot-57 & 1.540 & 0.160 & 0.1250 & 0.0140 & 8.000000 & 0.896000 & 0.0889 & 0.0075 & 0.45237 & 969 & 66 & 754 & 79 & 1380 & 180 & 0.29 & --- & --- \\
\hline SC & 0.840 & 0.039 & 8 & 0. & 83 & 2 & 5 & 32 & 0 & 620 & 22 & 623 & 43 & 680 & 110 & 0.00 & 623 & 43 \\
\hline SC-1-Spot-59 & 1.683 & 0.074 & 0.1640 & 0.0110 & 6.097561 & 0.408983 & 0.0718 & 0.0029 & 0.40903 & 997 & 29 & 977 & 62 & 979 & 83 & 0.02 & 977 & 62 \\
\hline SC & 0 & 0.048 & 16 & 60 & 10.91 & 0.7 & 5 & 30 & 3 & 554 & 28 & 564 & 35 & 550 & 110 & 0.02 & 564 & 35 \\
\hline SC-1-Spot-61 & 0.837 & 0.041 & 0.1079 & 0.0059 & 9.267841 & 0.506768 & 0.0579 & 0.0023 & 0.43506 & 623 & 25 & 659 & 34 & 511 & 92 & 0.05 & 659 & 34 \\
\hline SC-1-S & 0.717 & 0.034 & 0.0892 & 0.0052 & 11.210760 & 0.653542 & 0.0577 & 0.0027 & - & 547 & 20 & 550 & 30 & 500 & 100 & 0.01 & 550 & 30 \\
\hline SC-1-Spot-63 & 0.752 & 0.041 & 0.0925 & 0.0045 & 10.810810 & 0.525931 & 0.0588 & 0.0040 & 0.56035 & 566 & 24 & 570 & 27 & 500 & 150 & 0.01 & 570 & 27 \\
\hline SC-1-Spot-64 & 0.961 & 0.043 & 0.1129 & 0.0071 & 8.857396 & 0.557020 & 0.0627 & 0.0030 & 0.69003 & 681 & 22 & 688 & 41 & 688 & 99 & 0.01 & 888 & 41 \\
\hline SC-1-Spot-65 & 0.814 & 0.036 & 0.1021 & 0.0052 & 9.794319 & 0.498829 & 0.0599 & 0.0025 & 0.58457 & 605 & 20 & 626 & 31 & 584 & 92 & 0.03 & 626 & 31 \\
\hline SC-1-Spot-66 & 0.856 & 0.050 & 0.0932 & 0.0055 & 10.729610 & 0.633185 & 0.0721 & 0.0036 & 0.46142 & 638 & 28 & 574 & 32 & 985 & 99 & 0.11 & 574 & 32 \\
\hline SC-1-Spot-67 & 0.743 & 0.035 & 0.0908 & 0.0051 & 11.013220 & 0.618584 & 0.0598 & 0.0031 & 0.61542 & 562 & 20 & 559 & 30 & 610 & 110 & 0.01 & 559 & 30 \\
\hline SC-1-Spot-68 & 0.762 & 0.060 & 0.0914 & 0.0070 & 10.940920 & 0.837926 & 0.0592 & 0.0029 & 0.60447 & 570 & 33 & 563 & 41 & 540 & 100 & 0.01 & 563 & 41 \\
\hline 69 & 6.830 & 0.280 & 3750 & 0220 & 66667 & 0.156444 & 1339 & 0.0056 & 0.69344 & 2087 & 36 & 2040 & 100 & 2138 & 71 & 0.02 & 2138 & 71 \\
\hline
\end{tabular}


Isotopic Ratios

\begin{tabular}{|c|c|c|c|c|c|c|c|c|c|c|c|c|c|c|c|c|c|c|}
\hline \multirow[b]{2}{*}{$\begin{array}{c}\text { Sample and } \\
\text { analysis number }\end{array}$} & & & \multirow{2}{*}{\multicolumn{2}{|c|}{$\begin{array}{l}\text { Plot } \\
\text { Age }\end{array}$}} & \multirow[b]{2}{*}{$2 \sigma$} \\
\hline & $\begin{array}{l}{ }^{207} \mathrm{~Pb} / \\
{ }^{235} \mathrm{U}\end{array}$ & $2 \sigma$ & $\begin{array}{l}{ }^{206} \mathrm{~Pb} / \\
{ }^{238} \mathrm{U}\end{array}$ & $2 \sigma$ & $\begin{array}{l}{ }^{238} \mathrm{U} / \\
{ }^{206} \mathrm{~Pb}\end{array}$ & $\sigma$ & $\begin{array}{l}{ }^{207} \mathrm{~Pb} / \\
{ }^{206} \mathrm{~Pb}\end{array}$ & $2 \sigma$ & $\mathrm{EC}$ & ${ }^{207} \mathrm{~Pb} /$ & $2 \sigma$ & ${ }^{206} \mathrm{~Pb} /$ & $2 \sigma$ & $\begin{array}{l}{ }^{207} \mathrm{~Pb} / \\
{ }^{206} \mathrm{~Pb}\end{array}$ & $2 \sigma$ & & & \\
\hline$C$ & 0.714 & .041 & .0904 & .0056 & 1.061950 & 0.881040 & 0.0566 & 0.0024 & 0.56626 & 545 & 24 & 558 & 33 & 468 & 96 & 0.02 & 58 & 33 \\
\hline $\mathrm{SC}-$ & 2.880 & 0.130 & 2330 & 0.0110 & 4.291845 & 0.202619 & 0.0849 & 0.0033 & 0.60171 & 1370 & 34 & 1358 & 56 & 1317 & 78 & 0.01 & 1317 & 78 \\
\hline SC-1-Spot-90 & 5.350 & 0.250 & 0.3110 & 0.0170 & 3.215434 & 0.175763 & 0.1239 & 0.0067 & 0.76474 & 1874 & 41 & 1752 & 88 & 2008 & 92 & 0.07 & 2008 & 92 \\
\hline SC-1-Spot-92 & 0.720 & 0.038 & 0.0857 & 0.0048 & 11.668610 & 0.653551 & 0.0566 & 0.0031 & 0.49605 & 548 & 22 & 530 & 28 & 460 & 110 & 0.03 & 30 & 28 \\
\hline SC-1-Spot-93 & 0.883 & 0.049 & 0.1039 & 0.0057 & 9.624639 & 0.528012 & 0.0618 & 0.0036 & 0.48874 & 644 & 28 & 636 & 33 & 640 & 130 & 0.01 & 636 & 33 \\
\hline C-1-Spot-94 & 0.773 & 0.034 & 0.0897 & 0.0046 & 11.148270 & 0.571706 & 0.0612 & 0.0026 & 0.57355 & 579 & 19 & 553 & 27 & 670 & 93 & 0.05 & 553 & 27 \\
\hline SC-1-Spot-95 & 0.773 & 0.043 & 0.0932 & 0.0069 & 10.729610 & 0.794360 & 0.0596 & 0.0035 & 0.62584 & 578 & 25 & 573 & 40 & 570 & 130 & 0.01 & 573 & 40 \\
\hline SC-1-Spot-96 & 6.160 & 0.260 & 0.3520 & 0.0200 & 2.840909 & 0.161415 & 0.1230 & 0.0041 & 0.68162 & 1996 & 37 & 1966 & 95 & 1995 & 62 & 0.02 & 1995 & 62 \\
\hline SC-1-Spot-97 & 0.733 & 0.032 & 0.0852 & 0.0043 & 11.737090 & 0.592365 & 0.0608 & 0.0028 & 0.634 & 562 & 20 & 531 & 24 & 610 & 100 & 0.06 & 531 & 24 \\
\hline SC-1-Spot-98 & 0.741 & 0.033 & 0.0864 & 0.0060 & 11.574070 & 0.803755 & 0.0590 & 0.0031 & 0.76030 & 561 & 19 & 533 & 35 & 580 & 110 & 0.05 & 533 & 35 \\
\hline C-1-Spot-99 & 0.774 & 0.033 & 0.0875 & 0.0058 & 28570 & 551 & & 28 & 9291 & 580 & 19 & 540 & 34 & 635 & 94 & 0.07 & 0 & 34 \\
\hline SC-1-Spot-100 & 5.560 & 0.180 & 0.3270 & 0.0170 & 3.058104 & 0.158984 & 0.1169 & 0.0050 & 0.81464 & 1914 & 27 & 1817 & 80 & 1884 & 78 & 0.05 & 884 & 78 \\
\hline $\mathrm{SC}-1-\mathrm{Sp}$ & 0.756 & 0.026 & 0.0845 & 0.0038 & 11.834320 & 0.5 & 0.0602 & 0.0029 & 0.72977 & 573 & 15 & 523 & 23 & 570 & 100 & 0.10 & 523 & 23 \\
\hline SC-1-Spot-102 & 0.873 & 0.034 & 0.0999 & 0.0043 & 10.010010 & 0.430861 & 0.0607 & 0.0022 & 0.52449 & 635 & 18 & 613 & 25 & 617 & 79 & 0.04 & 613 & 25 \\
\hline SC-1-S & 0.792 & 0.043 & 0.0907 & 0.0042 & 11.025360 & 0.5 & 0.0613 & 0.0033 & 0.57381 & 589 & 24 & 559 & 25 & 640 & 120 & 0.05 & 559 & 25 \\
\hline SC-1-Spot-104 & 0.867 & 0.035 & 0.0993 & 0.0049 & 10.070490 & 0.496933 & 0.0599 & 0.0023 & 0.51495 & 632 & 19 & 609 & 29 & 587 & 81 & 0.04 & 09 & 29 \\
\hline SC-1-Spot-105 & 0.689 & 0.040 & 0.0834 & 0.0056 & 11.990410 & 0.805111 & 0.0602 & 0.0034 & 0.63756 & 529 & 23 & 515 & 33 & 580 & 120 & 0.03 & 515 & 33 \\
\hline $\mathrm{C}-1-\mathrm{Sp}$ & 0.800 & 0.052 & 0.0916 & 0.0059 & 7030 & 0.7 & 0.0610 & 0.0037 & 0.70741 & 592 & 29 & 564 & 35 & 580 & 130 & 0.05 & 564 & 35 \\
\hline SC-1-Spot-107 & 0.678 & 0.039 & 0.0833 & 0.0060 & 12.004800 & 0.864692 & 0.0594 & 0.0034 & 0.68265 & 522 & 23 & 514 & 36 & 530 & 120 & 0.02 & 514 & 36 \\
\hline SC-1-Spo & 2.020 & 0.110 & 0.1910 & 0.0130 & 5.235602 & 0.411173 & 0.0780 & 0.0040 & 0.81016 & 1122 & 36 & 1122 & 69 & 1110 & 100 & 0.00 & 1110 & 100 \\
\hline SC-1-Spot-109 & 0.649 & 0.041 & 0.0820 & 0.0081 & 120 & 1.204640 & 610 & 051 & 749 & 504 & 25 & 506 & 48 & 540 & 170 & 0.00 & 506 & 48 \\
\hline SC-1-Spot-110 & 0.804 & 0.045 & 0.0915 & 0.0076 & 8960 & 0.907761 & 0.0646 & 0.0040 & 0.73978 & 603 & 25 & 562 & 44 & 780 & 130 & 0.07 & 562 & 44 \\
\hline SC-1-Spo & 0.856 & 0.043 & 0.0989 & 0.0099 & 220 & 1. & 644 & 050 & 0.86378 & 625 & 23 & 605 & 58 & 680 & 160 & 0.03 & 605 & 58 \\
\hline SC-1-Spot-112 & 1.016 & 0.073 & 0.1205 & 0.0088 & 8.298755 & 0.606050 & .0614 & 0.0037 & 0.44765 & 711 & 35 & 731 & 50 & 640 & 120 & 0.03 & 731 & 50 \\
\hline SC-1-Spot-113 & 0.746 & 0.049 & 0.0924 & 0.0066 & 10.822510 & 0.773037 & 0.0571 & 0.0033 & 0.43563 & 566 & 30 & 568 & 39 & 510 & 120 & 0.00 & 568 & 39 \\
\hline SC-1-Spot-114 & 1.047 & 0.043 & 0.1170 & 0.0065 & 8.547009 & 0.474834 & 0.0655 & 0.0032 & 0.68189 & 725 & 21 & 712 & 38 & 750 & 100 & 0.02 & 712 & 38 \\
\hline SC-1-Spot-115 & 0.752 & 0.038 & 0.0932 & 0.0062 & 10.729610 & 0.713773 & 0.0584 & 0.0032 & 0.75046 & 571 & 20 & 573 & 37 & 510 & 120 & 0.00 & 573 & 37 \\
\hline SC-1-Spot-116 & 0.846 & 0.047 & 0.1009 & 0.0071 & 9.910803 & 0.697391 & 0.0606 & 0.0033 & 0.57148 & 618 & 26 & 625 & 43 & 610 & 120 & 0.01 & 625 & 43 \\
\hline SC-1-Spot-117 & 0.831 & 0.035 & 0.0957 & 0.0067 & 10.449320 & 0.731562 & 0.0620 & 0.0027 & 0.84942 & 615 & 19 & 588 & 39 & 669 & 97 & 0.05 & 588 & 39 \\
\hline SC-1-Spot & 0.705 & 0.047 & 0.0847 & 0.0054 & 11.806380 & 0.752709 & 586 & 0.0035 & 0.61670 & 546 & 28 & 529 & 33 & 520 & 120 & 0.03 & 529 & 33 \\
\hline SC-1-Spot-119 & 2.820 & 0.170 & 0.2320 & 0.0140 & 4.310345 & 0.260107 & 0.0897 & 0.0037 & 0.41955 & 1364 & 45 & 1355 & 72 & 1432 & 82 & 0.01 & 1432 & 82 \\
\hline SC-1-Spot-120 & 0.717 & 0.047 & 0.0865 & 0.0047 & 11.560690 & 0.62 & 599 & 0.0035 & 0.31023 & 550 & 25 & 538 & 29 & 570 & 120 & 0.02 & 538 & 29 \\
\hline SC-1-Spot-139 & 0.203 & 0.011 & 0.0231 & 0.0018 & 43.290040 & 3.373250 & 0.0598 & 0.0032 & 0.66537 & 187 & 9.4 & 147 & 11 & 580 & 120 & 0.27 & - & -- \\
\hline SC-1-Spot-140 & 10.570 & 0.590 & 0.4760 & 0.0400 & 2.100840 & 0.176541 & 0.1577 & 0.0084 & 0.72273 & 2479 & 51 & 2510 & 170 & 2430 & 83 & 0.01 & 2430 & 83 \\
\hline SC-1-Spot-142 & 0.815 & 0.046 & 0.0950 & 0.0096 & 10.526320 & 0.764543 & 0.0643 & 0.0061 & 0.90966 & 609 & 28 & 583 & 56 & 660 & 190 & 0.04 & 583 & 56 \\
\hline SC-1-Spot-143 & 3.630 & 0.170 & 0.2750 & 0.0190 & 3.636364 & 0.251240 & 45 & 036 & 0.68018 & 1565 & 34 & 1559 & 95 & 1522 & 71 & 0.00 & 522 & 71 \\
\hline SC-1-Spot-144 & 0.634 & 0.029 & 0.0751 & 0.0040 & 13.315580 & 0.709219 & 0.0579 & 0.0027 & 0.61697 & 499 & 17 & 466 & 24 & 520 & 110 & 0.07 & 466 & 24 \\
\hline SC-1-Spot-145 & 0.702 & 0.042 & 0.0880 & 0.0058 & 11.363640 & 0.748967 & 0.0569 & 0.0034 & 0.60610 & 540 & 24 & 543 & 34 & 450 & 130 & 0.01 & 543 & 34 \\
\hline SC-1-Spot-146 & 0.668 & 0.037 & 0.0820 & 0.0056 & 12.195120 & 0.832838 & 0.0599 & 0.0039 & 0.56601 & 517 & 22 & 507 & 33 & 530 & 140 & 0.02 & 507 & 33 \\
\hline SC-1-Spot-147 & 5.590 & 0.280 & 0.3400 & 0.0230 & 2.941176 & 0.198962 & 0.1193 & 0.0049 & 0.59593 & 1912 & 41 & 1870 & 110 & 1937 & 76 & 0.02 & 1937 & 76 \\
\hline SC-1-Spot-148 & 11.820 & 0.810 & 0.4710 & 0.0430 & 2.123142 & 0.193833 & 0.1800 & 0.0110 & 0.75018 & 2574 & 66 & 2450 & 190 & 2640 & 100 & 0.05 & 2640 & 100 \\
\hline
\end{tabular}


Appendix B. Continued.

\begin{tabular}{|c|c|c|c|c|c|c|c|c|c|c|c|c|c|c|c|c|c|c|}
\hline $\begin{array}{c}\text { Sample and } \\
\text { analysis number }\end{array}$ & \multicolumn{9}{|c|}{ Isotopic Ratios } & \multicolumn{6}{|c|}{ Final Isotopic Ages (Ma) } & Con. & $\begin{array}{l}\text { Plot } \\
\text { Age }\end{array}$ & $2 \sigma$ \\
\hline SC-1-Spot-149 & 1.143 & 067 & 1256 & 0.0083 & 961783 & 0.526137 & 0657 & 0.0026 & 0.44799 & 768 & 31 & 761 & 48 & 784 & 86 & 0.01 & 761 & 48 \\
\hline SC-1-Spot-150 & 0.906 & 0.052 & 0.1086 & 0.0072 & 9.208103 & 0.610482 & 0.0593 & 0.0030 & 0.56211 & 651 & 27 & 663 & 42 & 570 & 120 & 0.02 & 663 & 42 \\
\hline SC-1-Spot-152 & 0.711 & 0.034 & 0.0863 & 0.0046 & 11.587490 & 0.617641 & 0.0583 & 0.0031 & 0.62253 & 543 & 20 & 533 & 27 & 510 & 120 & 0.02 & 533 & 27 \\
\hline SC-1-Spot-153 & 1.660 & 0.093 & 1760 & 0.0150 & 5.681818 & 0.484246 & 0700 & 0.0036 & 0.7658 & 992 & 33 & 1036 & 84 & 40 & 100 & 0.04 & 40 & 100 \\
\hline SC-1-Spot-154 & 0.889 & 0.066 & 0.0971 & 0.0076 & 10.298660 & 0.806074 & 0.0666 & 0.0046 & 0.50690 & 639 & 34 & 596 & 44 & 770 & 150 & 0.07 & 596 & 44 \\
\hline SC-1-Spot-155 & 6.310 & 0.440 & 0.3740 & 0.0340 & 2.673797 & 0.243072 & 1198 & 0.0070 & 0.65928 & 2006 & 61 & 2030 & 160 & 1930 & 110 & 0.01 & 1930 & 110 \\
\hline SC-1-Spot-156 & 6.600 & 0.470 & 0.3550 & 0.0350 & 2.816901 & 0.277723 & 0.1383 & 0.0083 & 0.68733 & 2057 & 58 & 1930 & 170 & 2180 & 110 & 0.07 & 2180 & 110 \\
\hline SC-1-Spot-159 & 0.810 & 0.044 & 0.1029 & 0.0069 & 9.718173 & 0.651656 & 0.0579 & 0.0030 & 0.60274 & 599 & 24 & 630 & 40 & 500 & 110 & 0.05 & 630 & 40 \\
\hline SC-1-Spot-160 & 3.470 & 0.220 & 0.2610 & 0.0220 & 3.831418 & 0.322955 & $0097-3-3-1$ & 0.0063 & 0.61561 & 1514 & 48 & 1480 & 110 & 1540 & 120 & 0.02 & 1540 & 120 \\
\hline SC-1-Spot-161 & 0.733 & 0.039 & 0.0930 & 0.0065 & 10.752690 & 0.751532 & 0.0577 & 0.0030 & 0.53765 & 560 & 22 & 572 & 38 & 540 & 120 & 0.02 & 572 & 38 \\
\hline SC-1-S & 0.719 & 0.035 & 0.0856 & 0.0058 & 11.682240 & 0.791554 & 5 & 0.0030 & 0 & 55 & 20 & 529 & 34 & 622 & 97 & 0.04 & 529 & 34 \\
\hline SC-1-Spot-163 & 0.766 & 0.058 & 0.0868 & 0.0059 & 11.520740 & 0.783092 & 0.0626 & 0.0033 & 0.27500 & 571 & 32 & 536 & 35 & 660 & 120 & 0.07 & 536 & 35 \\
\hline SC-1-Spot-164 & 6.710 & 0.400 & 0.3750 & 0.0260 & 2.666667 & 0.184889 & 0.1290 & 0.0068 & 036 & 2059 & 53 & 2060 & 120 & 2066 & 96 & 0.00 & 2066 & 96 \\
\hline SC-1-Spot-165 & 3.470 & 0.230 & 0.2260 & 0.0230 & 4.424779 & 0.391573 & 0.1149 & 0.0077 & 0.73316 & 1519 & 48 & 1300 & 120 & 1830 & 120 & 0.17 & --- & --- \\
\hline SC-1-Spot-166 & 0.886 & 0.043 & 0.1024 & 0.0062 & 9.765625 & 0.591278 & 0.0635 & 0.0033 & 0.00720 & (34) & 22 & 627 & 36 & 680 & 110 & 0.03 & 627 & 36 \\
\hline SC-1-Spot-167 & 0.884 & 0.077 & 0.0970 & 0.0069 & 10.309280 & 0.733340 & 0.0672 & 0.0042 & 0.51846 & 646 & 43 & 595 & 41 & 780 & 130 & 0.09 & 595 & 41 \\
\hline SC-1-Spot-192 & 0.694 & 0.044 & 0.0941 & 0.0077 & 10.626990 & 0.869584 & 0.0562 & 0.0038 & 0.63210 & 53 & 26 & 578 & 45 & 400 & 140 & 0.08 & 578 & 45 \\
\hline SC-1-Spot-193 & 0.689 & 0.039 & 0.0900 & 0.0067 & 11.111110 & 0.827161 & 0.0564 & 0.0028 & 0.66797 & 529 & 23 & 554 & 39 & 450 & 100 & 0.05 & 554 & 39 \\
\hline SC-1-Spot-194 & 0.833 & 0.050 & 0.0999 & 0.0060 & 10.010010 & 0.601202 & 0.0602 & 0.0034 & $0.3913 /$ & 616 & 27 & 613 & 35 & 580 & 130 & 0.00 & 613 & 35 \\
\hline SC-1-Spot-195 & 0.836 & 0.043 & 0.1069 & 0.0073 & 9.354537 & 0.638804 & 0.0584 & 0.0028 & 0.67932 & 614 & 24 & 653 & 42 & 500 & 100 & 0.06 & 653 & 42 \\
\hline SC-1-Spot-196 & 0.850 & 0.060 & 0.0960 & 0.0069 & 10.416670 & 0.651042 & 0.0645 & 0.0043 & 0.46027 & 620 & 33 & 590 & 41 & 720 & 150 & 0.05 & 590 & 41 \\
\hline SC-1-Spot-197 & 0.674 & 0.040 & 0.0851 & 0.0049 & 11.750880 & 0.676608 & 0.0559 & 0.0025 & 0.19878 & 20 & 24 & 526 & 29 & 484 & 94 & 0.01 & 26 & 29 \\
\hline SC-1-Spot-198 & 6.300 & 0.320 & 0.3630 & 0.0270 & 2.754821 & 0.204904 & 0.1264 & 0.0063 & 0.78897 & 2014 & 45 & 1980 & 120 & 2014 & 91 & 0.02 & 2014 & 91 \\
\hline SC-1-Spot-199 & 0.682 & 0.037 & $0.08 / 2$ & 0.0069 & 11.467890 & 0.907436 & 0.0581 & 0.0036 & 0.08434 & 329 & 21 & 508 & 41 & 500 & 120 & 0.02 & 538 & 41 \\
\hline SC-1-Spot-200 & 0.745 & 0.040 & 0.0960 & 0.0077 & 10.416670 & 0.835504 & 0.0582 & 0.0034 & 0.75734 & 562 & 23 & 596 & 46 & 480 & 130 & 0.06 & 596 & 46 \\
\hline SC-1-Spot-201 & 6.540 & 0.280 & 0.3720 & 0.0230 & 2.688172 & 0.166204 & 0.1307 & 0.0052 & 0.73444 & 2055 & 38 & 2030 & 110 & 2098 & 75 & 0.01 & 2098 & 75 \\
\hline SC-1-Spot-202 & 0.728 & 0.034 & 0.0933 & 0.0066 & 10.718110 & 0.758195 & 0.0587 & 0.0035 & 0.77447 & 553 & 20 & 574 & 39 & 500 & 130 & 0.04 & 574 & 39 \\
\hline SC-1-Spot-203 & 1.080 & 0.120 & 0.0972 & 0.0074 & 10.288070 & 0.783248 & 0.0851 & 0.0089 & 0.07488 & 726 & 54 & 603 & 42 & 1160 & 160 & 0.20 & --- & --- \\
\hline SC-1-Spot-204 & 0.717 & 0.034 & 0.0884 & 0.0048 & 11.312220 & 0.614238 & 0.0587 & 0.0034 & 0.55917 & 546 & 20 & 545 & 28 & 540 & 130 & 0.00 & 545 & 28 \\
\hline SC-1-Spot-205 & 0.742 & 0.029 & 0.0863 & 0.0044 & 11.587490 & 0.590787 & 0.0605 & 0.0025 & 0.68487 & 562 & 17 & 533 & 26 & 607 & 94 & 0.05 & 533 & 26 \\
\hline SC-1-Spot-206 & 0.708 & 0.041 & 0.0844 & 0.0055 & 11.848340 & 0.772108 & 0.0596 & 0.0029 & 0.62769 & 535 & 22 & 522 & 33 & 590 & 100 & 0.02 & 522 & 33 \\
\hline SC-1-Spot-207 & 0.821 & 0.038 & 0.0942 & 0.0056 & 10.615710 & 0.631083 & 0.0616 & 0.0022 & 0.65730 & 606 & 21 & 580 & 33 & 652 & 79 & 0.04 & 580 & 33 \\
\hline
\end{tabular}


Appendix B. Continued.

\begin{tabular}{|c|c|c|c|c|c|c|c|c|c|c|c|c|c|c|c|c|c|c|}
\hline $\begin{array}{c}\text { Sample and } \\
\text { analysis number }\end{array}$ & \multicolumn{9}{|c|}{ Isotopic Ratios } & \multicolumn{6}{|c|}{ Final Isotopic Ages (Ma) } & Con. & $\begin{array}{l}\text { Plot } \\
\text { Age }\end{array}$ & 20 \\
\hline SC-1-Spot-208 & 0.722 & 046 & 0871 & 040 & 1.481060 & 0.527259 & 0599 & 031 & 78 & 547 & 27 & 38 & 23 & 580 & 100 & 0.02 & 38 & 23 \\
\hline SC-1-Spot-209 & 0.902 & 0.044 & 0.1060 & 0.0075 & 9.433962 & 0.667497 & 0.0605 & 0.0029 & 0.69186 & 650 & 24 & 648 & 43 & 610 & 110 & 0.00 & 648 & 43 \\
\hline SC-1-Spot-211 & 0.703 & 0.033 & 0.0824 & 0.0045 & 12.135920 & 0.662763 & 0.0598 & 0.0033 & 0.67689 & 541 & 19 & 510 & 27 & 570 & 110 & 0.06 & 510 & 27 \\
\hline SC-1-Spot-212 & 0.491 & 0.028 & 0.0547 & 0.0033 & 18.281540 & 1.102908 & .0610 & 0.0028 & 0.55375 & 406 & 20 & 343 & 20 & 646 & 89 & 0.18 & --- & - \\
\hline SC-1-Spot-213 & 0.924 & 0.061 & 0.1049 & 0.0081 & 9.532888 & 0.736095 & 0.0625 & 0.0034 & 0.60515 & 664 & 33 & 641 & 47 & 660 & 110 & 0.04 & 641 & 47 \\
\hline SC-1-Spot-214 & 0.743 & 0.042 & 0.0896 & 0.0055 & 11.160710 & 0.685089 & 0586 & 0.0032 & 0.44707 & 561 & 24 & 552 & 32 & 10 & 120 & 0.02 & 552 & 32 \\
\hline SC-1-Spot-215 & 0.743 & 0.032 & 0.0902 & 0.0072 & 11.086470 & 0.884951 & 0.0590 & 0.0033 & 0.74469 & 566 & 18 & 555 & 43 & 510 & 120 & 0.02 & 555 & 43 \\
\hline SC-1-Spot-218 & 0.924 & 0.055 & 0.1071 & 0.0083 & 9.337068 & 0.723601 & 0.0611 & 0.0032 & 0.67873 & 671 & 29 & 653 & 48 & 610 & 110 & 0.03 & 653 & 48 \\
\hline SC-1-Spot-219 & 0.753 & 0.047 & 0.0905 & 0.0065 & 11.049720 & 0.793627 & 年 & 0.0047 & 0.07052 & 566 & 28 & 557 & 38 & 720 & 160 & 0.02 & 557 & 38 \\
\hline SC-1-Spot-220 & 0.714 & 0.044 & 0.0881 & 0.0066 & 11.350740 & 0.850339 & 0.0580 & 0.0029 & 0.56098 & 543 & 26 & 543 & 39 & 520 & 110 & 0.00 & 543 & 39 \\
\hline SC-1-S & 2 & 7 & 2 & 87 & 10.5 & 0.739266 & 2 & 030 & 0 & 5 & 27 & 84 & 51 & 0 & 120 & 0.05 & 584 & 51 \\
\hline SC-1-Spot-240 & 0.796 & 0.041 & 0.0958 & 0.0065 & 10.438410 & 0.708243 & 0.0595 & 0.0030 & 0.70453 & 595 & 22 & 596 & 40 & 610 & 110 & 0.00 & 596 & 40 \\
\hline S & 0.719 & 51 & 80 & (3) & .363640 & 4 & 0.0608 & 7 & 0.45831 & 549 & 1 & 43 & 33 & 10 & 40 & 01 & 13 & 3 \\
\hline SC-1-Spot-242 & 0.751 & 0.045 & 0.0890 & 0.0065 & 11.235960 & 0.820604 & 0.0624 & 0.0033 & 0.55133 & 570 & 25 & 548 & 38 & 640 & 110 & 0.04 & 548 & 38 \\
\hline SC- 1 & 0 & 0 & 0.3710 & 0 & 8 & 1 & 0.1199 & 2 & 0.73577 & 33 & 38 & 2030 & 110 & 1953 & 6 & 02 & 1953 & 6 \\
\hline SC-1-Spot-244 & 0.691 & 0.040 & 0.0876 & 0.0069 & 11.415530 & 0.899168 & 0.0612 & 0.0033 & 0.68549 & 535 & 25 & 540 & 41 & 630 & 120 & 0.01 & 540 & 41 \\
\hline SC-1-Spot-251 & 0.682 & 0.042 & 0.0944 & 0.0062 & 10.593220 & 0.695741 & 0.0568 & 0.0030 & 0.59089 & 52 & 26 & 586 & 37 & 440 & 120 & 0.11 & 586 & 37 \\
\hline SC-1-Spot-252 & 0.913 & 0.044 & 0.1080 & 0.0063 & 259259 & 0.540124 & 0.0606 & 0.0027 & 0.59771 & 65 & 23 & 660 & 37 & 650 & 97 & 0.01 & 660 & 37 \\
\hline SC-1-Spot-253 & 0.737 & 0.046 & 0.0928 & 0.0073 & 10.775860 & 0.847670 & 0.0598 & 0.0036 & 0.64201 & 566 & 27 & 570 & 43 & 580 & 130 & 0.01 & 570 & 43 \\
\hline SC-1-S & 0.683 & 0.039 & 0.0879 & 0.0043 & 11.376560 & 0.556 & 0.0575 & 0.0026 & 02 & 5 & 24 & 543 & 26 & 519 & 87 & 0.02 & 543 & 26 \\
\hline SC-1-Spot-255 & 0.720 & 0.031 & 0.0919 & 0.0057 & 10.881390 & 0.674907 & 0.0585 & 0.0026 & 0.76619 & 555 & 18 & 566 & 33 & 550 & 88 & 0.02 & 566 & 33 \\
\hline SC & 0.912 & 040 & 0.1057 & 7 & 38 & 2 & 3 & 6 & 6 & 654 & 26 & 7 & 34 & 0 & 120 & 01 & 47 & 34 \\
\hline SC-1-Spot-257 & 3.620 & 0.170 & 0.2900 & 0.0190 & 3.448276 & 0.225922 & 0.0932 & 0.0035 & 0.69826 & 1552 & 38 & 1649 & 89 & 1482 & 68 & 0.06 & 1482 & 68 \\
\hline SC-1-S & 0.847 & 0.038 & 0.1010 & 0.0054 & 0 & 0 & 7 & 3 & 0.73497 & 624 & 22 & 619 & 32 & 0 & 110 & 1 & 19 & 2 \\
\hline SC-1-Spot-259 & 0.808 & 0.047 & 0.1028 & 0.0062 & 9.727626 & 0.586686 & 0.0566 & 0.0034 & 0.47100 & 597 & 27 & 630 & 36 & 440 & 130 & 0.05 & 630 & 36 \\
\hline SC- & 99 & 32 & 15 & 63 & 320 & 2 & 6 & 6 & 0 & 518 & 20 & 522 & 37 & 20 & 120 & 01 & 2 & 7 \\
\hline SC-1-Spot-261 & 0.838 & 0.048 & 0.1005 & 0.0068 & 9.950249 & 0.673251 & 0.0622 & 0.0035 & 0.48406 & 61 & 26 & 616 & 40 & 640 & 120 & 0.00 & 616 & 40 \\
\hline SC-1- & 0.677 & 0.045 & 0.0863 & 0.0072 & 7490 & 0.966743 & 0.0569 & 0.0029 & 0 & 5 & 26 & 32 & 42 & 450 & 110 & 0.01 & 32 & 2 \\
\hline SC-1-Spot-263 & 0.778 & 0.051 & 0.0830 & 0.0053 & 12.048190 & 0.769342 & 0.0657 & 0.0040 & 0.39817 & 579 & 30 & 513 & 31 & 820 & 140 & 0.13 & 513 & 31 \\
\hline SC-1-Spot-264 & 0.863 & 0.043 & 0.1119 & 0.0066 & 8.936550 & 0.527089 & 0.0575 & 0.0031 & 0.66525 & 028 & 23 & 682 & 38 & 520 & 120 & 0.08 & 682 & 38 \\
\hline SC-1-Spot-265 & 0.705 & 0.042 & 0.0923 & 0.0067 & 10.834240 & 0.786451 & 0.0586 & 0.0032 & 0.70223 & 543 & 26 & 568 & 40 & 500 & 120 & 0.04 & 568 & 40 \\
\hline SC-1-Spot-266 & 0.827 & 0.038 & 0.1021 & 0.0071 & 9.794319 & 0.681094 & 0.0573 & 0.0034 & 0.71963 & 613 & 22 & 625 & 41 & 450 & 130 & 0.02 & 625 & 41 \\
\hline
\end{tabular}


Isotopic Ratios

\begin{tabular}{|c|c|c|c|c|c|c|c|c|c|c|c|c|c|c|c|c|c|c|}
\hline $\begin{array}{l}\text { Sample and } \\
\text { nalysis number }\end{array}$ & $\begin{array}{c}{ }^{207} \mathrm{~Pb} / \\
{ }^{235} \mathrm{U}\end{array}$ & $2 \sigma$ & $\begin{array}{c}{ }^{206} \mathrm{~Pb} / \\
{ }^{238} \mathrm{U}\end{array}$ & $2 \sigma$ & $\begin{array}{l}{ }^{238} \mathrm{U} / \\
{ }^{206} \mathrm{~Pb}\end{array}$ & $2 \sigma$ & $\begin{array}{c}{ }^{207} \mathrm{~Pb} / \\
{ }^{206} \mathrm{~Pb}\end{array}$ & $\sigma$ & $\mathrm{EC}$ & $\begin{array}{c}{ }^{207} \mathrm{~Pb} / \\
{ }^{235} \mathrm{U}\end{array}$ & $2 \sigma$ & $\begin{array}{c}{ }^{206} \mathrm{~Pb} / \\
{ }^{238} \mathrm{U}\end{array}$ & $2 \sigma$ & $\begin{array}{l}{ }^{207} \mathrm{~Pb} / \\
{ }^{206} \mathrm{~Pb}\end{array}$ & $2 \sigma$ & Con. & $\begin{array}{l}\text { Plot } \\
\text { Age }\end{array}$ & \\
\hline$C-1$ & 2.240 & 140 & 2190 & 160 & 66210 & 54 & 0781 & 36 & & 1202 & 43 & 1272 & 84 & 1122 & 94 & 0.06 & 1122 & \\
\hline $\mathrm{C}-1$ & 0.769 & 0 & 024 & 0070 & 9.765625 & 0.667572 & 568 & 0.0047 & 0 & 574 & 29 & 627 & 41 & 440 & 170 & 0.08 & 627 & 4 \\
\hline 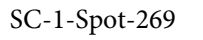 & 0.727 & 0.035 & 885 & 063 & 99440 & 4367 & 2 & 30 & 0 . & 553 & 20 & 546 & 37 & 610 & 110 & 0.01 & 46 & 37 \\
\hline C-1-Spot-270 & 0.940 & .120 & 1034 & 0.0086 & 9.671180 & 0.804373 & 0.0692 & 0.0075 & 0.08033 & 654 & 59 & 632 & 50 & 790 & 230 & 0.03 & 632 & \\
\hline
\end{tabular}

Sample SC-4: Jam Brook Complex

\begin{tabular}{|c|c|c|c|c|c|c|c|c|c|c|c|c|c|c|c|c|c|}
\hline C-4-Spot-8 & 06 & 5 & .0755 & D & 30 & 39 & 4 & 9 & 0.58169 & 480 & 16 & 59 & 24 & 38 & 9 & 02 & 69 \\
\hline C-4-Spot-9 & 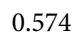 & & & & 5030 & 0.719267 & 0559 & 0022 & .80194 & 464 & 15 & 468 & 25 & 22 & 36 & .01 & 468 \\
\hline C-4-Spot- 10 & 596 & . 022 & 0.0761 & $t$ & 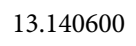 & 7 & 0.0569 & 7 & 071105 & 474 & 14 & 473 & 20 & 471 & 67 & 0.00 & 473 \\
\hline C-4-Spot-11 & 884 & .023 & 7 & & 20 & 46 & 8 & 18 & 0 & 68 & 4 & 58 & 0 & 02 & 9 & 02 & 58 \\
\hline C-4-Spot-12 & .587 & 0.024 & 0.0740 & L & 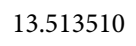 & & 2 & & & 468 & 16 & 0 & 25 & 1 & 2 & 2 & 460 \\
\hline-4 & 59 & 024 & 56 & & 10 & 88 & 2 & 17 & 0.54734 & 6 & 16 & 69 & 20 & 81 & 7 & 01 & 469 \\
\hline$t-14$ & 656 & 2 & 08 & 5 & ) & 96 & .0587 & 0.0023 & 0.54512 & & 6 & 6 & 21 & 3 & 7 & 3 & 6 \\
\hline Snot 15 & 598 & 019 & 0752 & & 70 & 500 & 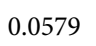 & 18 & 075297 & 1 & 12 & 167 & 22 & 21 & 68 & .02 & 467 \\
\hline & 600 & 0.028 & 0.0731 & 7 & 0 & & & & & 476 & 8 & 4 & 16 & 10 & 10 & 05 & 54 \\
\hline 74 Sout 25 & 592 & 02 & .0755 & & 30 & 836 & 570 & - & t & 171 & 16 & 469 & 18 & 08 & 72 & 00 & 469 \\
\hline ot-36 & .585 & 0.025 & 0.0739 & 9 & 1800 & & 0.0568 & 19 & & 466 & 16 & 459 & 23 & 67 & 5 & 0.02 & 459 \\
\hline$C 4 \mathrm{Snot} 37$ & .586 & 33 & 0.0765 & 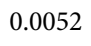 & 00 & 3547 & 0 & 23 & 056261 & 470 & 22 & 475 & 31 & 55 & 91 & .01 & 475 \\
\hline tot -38 & 583 & .019 & 0.0749 & 2 & 1130 & & & & & 466 & 12 & 465 & 19 & 460 & 65 & 0.00 & 465 \\
\hline 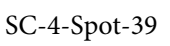 & .604 & 017 & 0.0740 & & 10 & 97 & 6 & 20 & 0.64256 & 479 & 1 & 60 & 19 & 03 & 74 & .04 & 460 \\
\hline 0 & 59 & .023 & .0754 & $\mathrm{p}$ & 2600 & 28 & 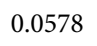 & 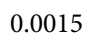 & 0.52677 & 474 & 15 & 468 & 22 & 09 & 99 & 01 & 468 \\
\hline+1 & 613 & 027 & 0.0752 & & 0 & 00 & 1 & 5 & & 484 & 7 & 67 & 29 & 16 & 94 & .04 & 467 \\
\hline at 4 ? & 59 & 026 & 071 & & 0 & c & 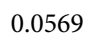 & & & 469 & 1 & 447 & 26 & 476 & 91 & 5 & 447 \\
\hline 10 & 573 & 0023 & 0.0713 & & 50 & 4855 & 78 & & & 9 & 5 & 443 & 28 & 41 & 4 & .04 & 443 \\
\hline 44 & 58 & 02 & $07-7>$ & & 80 & 400 & ( & 0 & 062822 & 466 & 13 & 460 & 19 & 460 & 84 & 1 & 460 \\
\hline - & 61 & 07 & & & 40 & 3120 & 585 & & & 2 & 16 & 470 & 22 & 39 & 1 & .03 & 470 \\
\hline C 4 Snot 4 & $-0,0>$ & ح & 075 & & 0 & 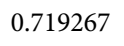 & 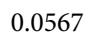 & 3 & 053806 & 465 & 18 & 468 & 25 & 451 & 87 & 0.01 & 468 \\
\hline & 6 & 象 & 0.0732 & 0045 & 200 & 0.839828 & 590 & 20 & & 77 & 17 & 154 & 27 & 74 & 88 & .05 & 454 \\
\hline $14 \mathrm{cn}$ & 594 & 024 & 0.0736 & & 0 & 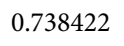 & 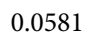 & & & 475 & 15 & 457 & 24 & 516 & 90 & 0.04 & 457 \\
\hline 49 & 626 & .039 & $0.0 / 91$ & . & 30 & 8868 & 0552 & 35 & & 1 & 24 & 489 & 39 & 20 & 50 & .00 & 489 \\
\hline & & & & & & & & & & & 20 & 481 & 31 & 410 & 120 & 0.02 & 481 \\
\hline 51 & 880 & 087 & $.1 / 20$ & (.010 & 953 & 0.371823 & 804 & 29 & 0.66706 & 069 & 31 & 1020 & 61 & 1216 & 59 & 0.05 & 1216 \\
\hline & & & & & & & & & & & 17 & & 29 & & & & \\
\hline 53 & $5 /$ & $J 23$ & 0.0759 & 5 & 30 & 6 & 53 & 4 & 0.77817 & 457 & 15 & 471 & 3 & 410 & 100 & 3 & 71 \\
\hline & & .020 & & & 0 & c & & & & & 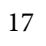 & 463 & 30 & & & 0.01 & 463 \\
\hline $54 \mathrm{c} n$ & 58 & 019 & & ? & 0 & c & 0.0558 & 0.0019 & 066205 & 468 & 12 & 467 & 21 & 443 & 79 & 0.00 & 467 \\
\hline & & $x+2>$ & & & 0 & 99 & & & & & 20 & 460 & 23 & 510 & 00 & 2 & 460 \\
\hline $54 \mathrm{c} n$ & 1000 & 0.024 & 0.0752 & 6 & 0 & ( & 0.0567 & 0.0022 & & & 15 & 467 & 28 & 480 & 86 & 0.00 & 467 \\
\hline & דנה & 0.019 & 0.0700 & 0.0031 & 0 & & & & & & 13 & 4 & & & & 22 & 39 \\
\hline 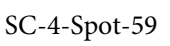 & 0.003 & 0.026 & & 0.0041 & & & & & & & 16 & & & & 84 & 0.02 & 476 \\
\hline & 578 & 0.023 & 0.0733 & 3 & 13. & & & & & & 15 & 455 & & 5 & & 0.02 & 455 \\
\hline & 14 & 34 & 0.0749 & 6 & 13.3511 & 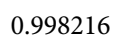 & & & & 405 & & & & & & 0.04 & 465 \\
\hline
\end{tabular}


Appendix B. Continued.

Isotopic Ratios

\begin{tabular}{|c|c|c|c|c|c|c|c|c|c|c|c|c|c|c|c|c|c|c|}
\hline \multirow[b]{2}{*}{$\begin{array}{l}\text { Sample and } \\
\text { analysis number }\end{array}$} & & & \multirow[b]{2}{*}{ Con. } & \multirow[b]{2}{*}{$\begin{array}{l}\text { Plot } \\
\text { Age }\end{array}$} & \multirow[b]{2}{*}{$2 \sigma$} \\
\hline & ${ }^{207} \mathrm{~Pb} /$ & $2 \sigma$ & $\begin{array}{c}{ }^{206} \mathrm{~Pb} / \\
{ }^{238} \mathrm{U}\end{array}$ & $J$ & $\begin{array}{l}{ }^{238} \mathrm{U} / \\
{ }^{206} \mathrm{~Pb}\end{array}$ & & $\begin{array}{l}{ }^{207} \mathrm{~Pb} / \\
{ }^{206} \mathrm{~Pb}\end{array}$ & 5 & & $\begin{array}{l}{ }^{207} \mathrm{~Pb} / \\
{ }^{235} \mathrm{U}\end{array}$ & $2 \sigma$ & $\begin{array}{l}{ }^{206} \mathrm{~Pb} / \\
{ }^{238} \mathrm{U}\end{array}$ & $2 \sigma$ & $\begin{array}{l}{ }^{207} \mathrm{~Pb} / \\
{ }^{206} \mathrm{~Pb}\end{array}$ & $2 \sigma$ & & & \\
\hline & 0.593 & 27 & 6 & & 3.774100 & 0.777876 & .0584 & 0018 & .66258 & 471 & 17 & 451 & 25 & 528 & 8 & & & 5 \\
\hline 1 & 609 & 038 & 753 & 46 & .280210 & 0.811275 & 0.0580 & 0035 & 33 & 479 & 23 & 467 & 27 & 500 & 20 & 0.03 & 67 & 27 \\
\hline C. & 606 & น & 768 & 7 & 0830 & 96848 & 0.0572 & 25 & & 480 & 13 & 476 & 28 & 521 & 9 & 0.01 & 6 & 28 \\
\hline SC-4-Spot-65 & 504 & 018 & 734 & 0 & 3.623980 & 0.556838 & 0.0593 & 0020 & & 479 & 12 & 456 & 18 & 567 & 75 & 0.05 & 56 & 18 \\
\hline $\mathrm{C}-4-\mathrm{S}_{\mathrm{H}}$ & 0576 & 0070 & 0 & 42 & 3.513510 & 0.766983 & 0.0564 & 0025 & 0.63993 & 463 & 18 & 460 & 25 & 476 & 99 & 0.01 & 460 & 25 \\
\hline C-4-Spot & 597 & 034 & 742 & & 13.477090 & 1.053465 & 0.0600 & 0.0026 & 0.63695 & 473 & 22 & 460 & 35 & 600 & 95 & 0.03 & 60 & 35 \\
\hline C-4-Spot-86 & 0.59 & 018 & 0.0738 & 0.0027 & 13.550140 & 0.495737 & 0.0584 & & & 475 & 12 & 459 & 16 & 529 & 63 & 0.03 & 459 & 16 \\
\hline C-4-S & 0.602 & 017 & 722 & 1 & 0420 & 685 & 0.0577 & .0021 & 49 & 478 & 1 & 449 & 18 & 507 & 79 & 0.06 & 49 & 18 \\
\hline C- 4 & 0.586 & 023 & 0.0721 & & 3.869630 & 0.730993 & 0.0593 & .0022 & 0.6 & 467 & 14 & 448 & 23 & 552 & 85 & 0.04 & 148 & 23 \\
\hline C-4-Spot-89 & 0.579 & $002 ?$ & 00740 & & & 693937 & .0558 & 0021 & & 463 & 14 & 460 & 23 & 449 & 82 & 0.01 & 160 & 23 \\
\hline$C-1$ & 593 & 022 & 754 & 0037 & 3.262600 & 0.650 & 0.0575 & 0017 & & 474 & 14 & 468 & 22 & 490 & 69 & 0.01 & 168 & 22 \\
\hline C & 0.60 & 0.021 & & & & & & & & 478 & 13 & 478 & 23 & 446 & 76 & 0.00 & 478 & 23 \\
\hline C-4- & 0.591 & 027 & 755 & 0.0047 & 13.245030 & 0.824525 & 0.0574 & .0023 & & 473 & 18 & 468 & 28 & 476 & 87 & 0.01 & 468 & 28 \\
\hline C-4-Spot & 0 & & 768 & & 3.020830 & 0.915527 & 0.0582 & .0024 & 0.56373 & 480 & 21 & 476 & 32 & 534 & 93 & 0.01 & 476 & 32 \\
\hline C-4 & 0.612 & 023 & 771 & & & & & & & 489 & 15 & 478 & 23 & 532 & 88 & 0.02 & 478 & 23 \\
\hline SC-4-Spot & 0.601 & 028 & 771 & & 2.970170 & 0.857949 & 0.0578 & 0.0019 & & 476 & 18 & 478 & 31 & 539 & 76 & 0.00 & 178 & 31 \\
\hline$C_{4}$ & 0 & 0.028 & & & & & & 26 & & 473 & 8 & 494 & 32 & 420 & 10 & 0.04 & 494 & 32 \\
\hline C-4-Spo & 0.603 & 0.027 & 9774 & 52 & 900 & 03 & 565 & 0025 & & 481 & 16 & 480 & 31 & 466 & 36 & 0.00 & 180 & 31 \\
\hline C-4-Sp & & & & & & & & & & 482 & 7 & 472 & 23 & 593 & 2 & 0.02 & 172 & 23 \\
\hline$C A \mathrm{~S}_{\mathrm{n}}$ & 0.598 & 0.023 & 0.0782 & 38 & 720 & & 572 & 7 & & 477 & 15 & 485 & 23 & 494 & 70 & 2 & 485 & 23 \\
\hline C-4-Spot-100 & 0.600 & 027 & 9776 & 0038 & 2.886600 & 045 & 0.0584 & 0.0022 & 006 & 479 & 18 & 481 & 23 & 534 & 77 & 0.00 & 481 & 23 \\
\hline$C$ & 0 & 0.021 & & & & & & & & 463 & 3 & 461 & 26 & 517 & 93 & 0.00 & 61 & 26 \\
\hline C-4-Spo & 0.623 & 018 & 796 & 32 & 62810 & 38 & & 0018 & & 491 & 11 & 497 & 20 & 513 & 58 & 1 & 197 & 20 \\
\hline C-4-Spot-103 & 0 & & & & & & & 0021 & & 489 & 16 & 493 & 31 & 512 & 80 & 0.01 & 493 & 31 \\
\hline C-4-Spot & 0.584 & 023 & 766 & 36 & 830 & & 572 & .0021 & & 468 & 15 & 475 & 21 & 500 & 33 & 1 & 475 & 21 \\
\hline C-4-Sp & 07 & 026 & 8 & & 830 & & 0.057 & & & 480 & 7 & 476 & 23 & 503 & 65 & 0.01 & 476 & 23 \\
\hline 06 & 505 & 24 & & & 890 & 73 & 71 & 023 & & 469 & 16 & 471 & 26 & 480 & 1 & 0.00 & 471 & 26 \\
\hline 07 & 638 & 025 & 818 & 41 & 2.224940 & 0.612741 & 580 & .0027 & & 500 & 15 & 507 & 24 & 496 & 98 & 0.01 & 507 & 24 \\
\hline C-4-Spot-126 & 96 & 0.029 & 5 & & 00 & & & & & 473 & 9 & 474 & 33 & 440 & 10 & 0.00 & 474 & 33 \\
\hline C-4-Spot-127 & 0.614 & 027 & 756 & 042 & 3.227510 & 0.734 & 0.0602 & 0.0025 & & 487 & 17 & 469 & 25 & 604 & 38 & 0.04 & 469 & 25 \\
\hline C-4-Spot-128 & 0 & 032 & 001 & 48 & 390 & & & & & 499 & 9 & 496 & 28 & 478 & 91 & 0.01 & 496 & 28 \\
\hline C-4-Spot-129 & & 39 & 56 & & .682240 & 1.637 & 617 & 56 & & 540 & 22 & 529 & 30 & 580 & 80 & 0.02 & 529 & 30 \\
\hline -4-Spot & 0.015 & 024 & 793 & 39 & 340 & 0.620181 & 0.0569 & .0020 & 0.58 & 486 & 15 & 492 & 23 & 477 & 75 & 0.01 & 492 & 23 \\
\hline C-4-Spot-131 & 526 & 031 & 9789 & & 12.674270 & & & & & 492 & 9 & 489 & 29 & 480 & 100 & 0.01 & 489 & 29 \\
\hline SC-4-Spot-132 & 05 & 022 & 50 & & 3.333330 & 0.693333 & 592 & 0.0024 & & 480 & 14 & 466 & 23 & 556 & 87 & 0.03 & 466 & 23 \\
\hline SC-4-Sp & 0.632 & 0.026 & 0.0770 & 042 & 12.987010 & & & & & 496 & 16 & 477 & 25 & 586 & 82 & 0.04 & 477 & 25 \\
\hline C-4-Spot-134 & 0 & 39 & 803 & 0.0076 & 12.453300 & 1.178644 & 0.0575 & 0.0035 & 0.77439 & 497 & 23 & 496 & 45 & 520 & 110 & 0.00 & 496 & 45 \\
\hline C-4-Spot-135 & 0.623 & 0.020 & 0.0801 & 0.0043 & 12.484390 & 0.670199 & & 0.0022 & 0.64460 & 495 & 18 & 501 & 27 & 430 & 90 & 0.01 & 501 & 27 \\
\hline C-4-Spot-136 & 0.626 & 0.026 & 0.0761 & 0.0039 & 13.140600 & 34 & 0.0572 & 022 & & 492 & 16 & 473 & 23 & 506 & 84 & 0.04 & 473 & 23 \\
\hline SC-4-Spot-137 & 0.625 & 032 & 0.0775 & 0.0046 & 2.903230 & 0.765869 & 0.0580 & 0.0027 & 0.21762 & 491 & 20 & 480 & 27 & 490 & 100 & 0.02 & 480 & 27 \\
\hline C-4-Spot-138 & 0.627 & .025 & 0803 & .0046 & 2.453300 & 0.713390 & .0566 & .0020 & 65682 & 493 & 6 & 497 & 27 & 481 & 76 & 0.01 & 197 & 77 \\
\hline
\end{tabular}


Appendix B. Continued.

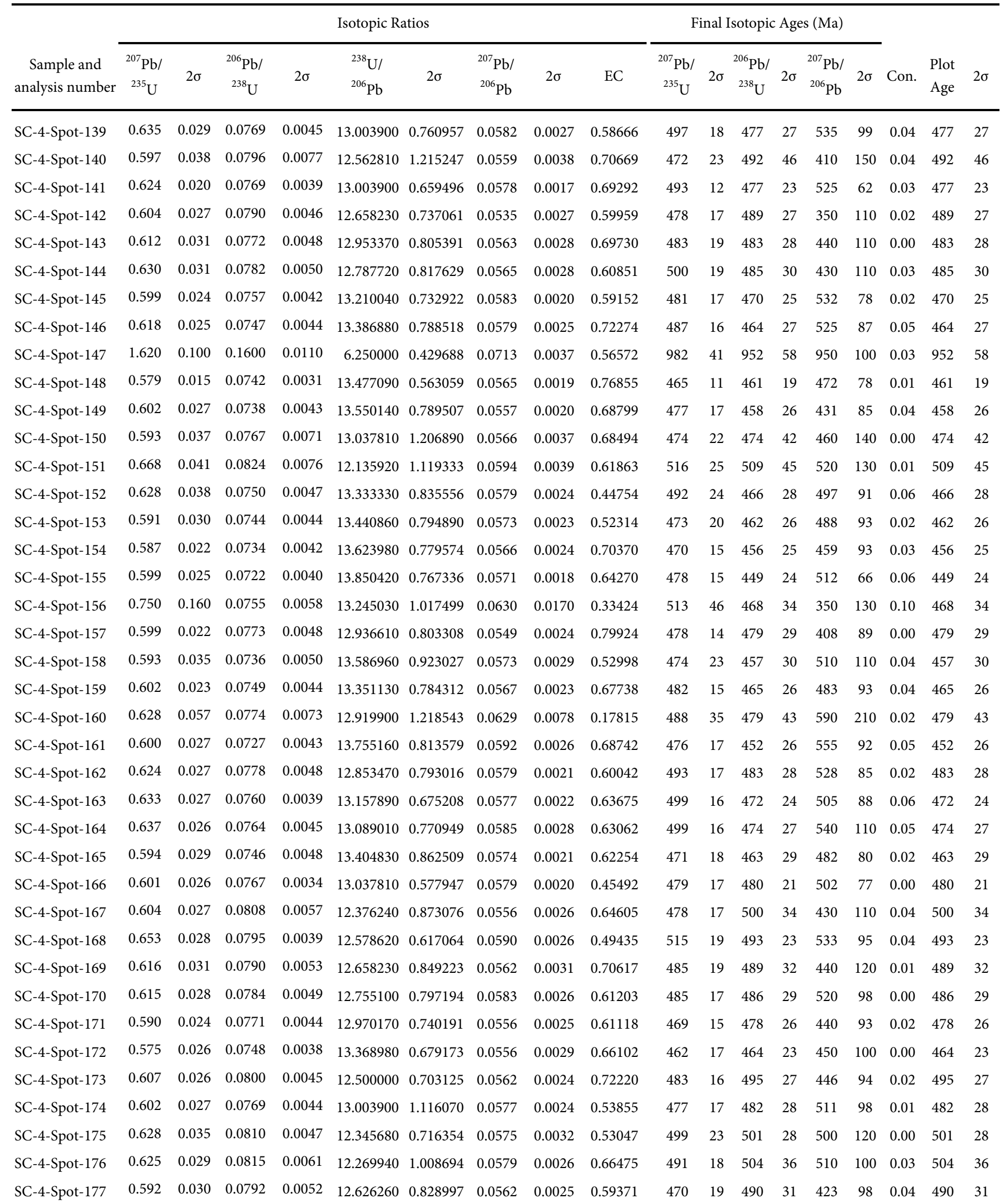


Appendix B. Continued.

\begin{tabular}{|c|c|c|c|c|c|c|c|c|c|c|c|c|c|c|c|c|c|c|}
\hline \multirow[b]{2}{*}{$\begin{array}{c}\text { Sample and } \\
\text { analysis number }\end{array}$} & \multicolumn{9}{|c|}{ Isotopic Ratios } & \multicolumn{6}{|c|}{ Final Isotopic Ages (Ma) } & \multirow[b]{2}{*}{ Con. } & \multirow[b]{2}{*}{$\begin{array}{l}\text { Plot } \\
\text { Age }\end{array}$} & \multirow[b]{2}{*}{$2 \sigma$} \\
\hline & $\begin{array}{l}{ }^{207} \mathrm{~Pb} / \\
{ }^{235} \mathrm{U}\end{array}$ & 2 & $\begin{array}{l}{ }^{206} \mathrm{~Pb} / \\
{ }^{238} \mathrm{U}\end{array}$ & $2 \sigma$ & $\begin{array}{l}{ }^{238} \mathrm{U} / \\
{ }^{206} \mathrm{~Pb}\end{array}$ & $2 \sigma$ & $\begin{array}{l}{ }^{207} \mathrm{~Pb} / \\
{ }^{206} \mathrm{~Pb}\end{array}$ & $2 \sigma$ & EC & $\begin{array}{l}{ }^{207} \mathrm{~Pb} / \\
{ }^{235} \mathrm{U}\end{array}$ & $2 \sigma$ & $\begin{array}{l}{ }^{206} \mathrm{~Pb} / \\
{ }^{238} \mathrm{U}\end{array}$ & $2 \sigma$ & $\begin{array}{l}{ }^{207} \mathrm{~Pb} / \\
{ }^{206} \mathrm{~Pb}\end{array}$ & $2 \sigma$ & & & \\
\hline \multicolumn{19}{|c|}{ ample SC-5: Jam Brook Complex } \\
\hline -5-Spot-38 & 4.180 & .310 & 2670 & 0210 & 5318 & 0.350685 & 1081 & 0.0047 & 329 & 1666 & 57 & 1520 & 110 & 1781 & 68 & 0.09 & 1781 & 68 \\
\hline - & 5.000 & 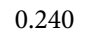 & 0.2610 & 0100 & 831418 & 0.322955 & 0978 & 0.0048 & 0.1072 & 1534 & 52 & 1508 & 95 & 1577 & 91 & .02 & 1577 & 91 \\
\hline C-5- & 3.880 & .210 & 2910 & .0190 & 436426 & 0.283417 & 0969 & 0.0023 & .47052 & 1637 & 42 & 1650 & 100 & 1562 & 48 & 0.01 & 1562 & 48 \\
\hline (J) & 2.040 & 0.130 & 0.1880 & 0.002 & 319149 & 0.424400 & 0944 & 0.0036 & 0.12070 & 1292 & 43 & 1108 & 63 & 1502 & 69 & .14 & 1502 & 69 \\
\hline C-5-S & 2.440 & 100 & 2180 & .0100 & 156 & 0.315630 & 0803 & 0.0021 & 0.40837 & 1248 & 30 & 1270 & 55 & 1200 & 54 & 0.02 & 1200 & 54 \\
\hline 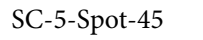 & 1.030 & 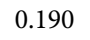 & 0.1870 & $0.02<0$ & 347594 & 0.686322 & 0748 & 0.0053 & 0.10035 & 1059 & 63 & 1090 & 120 & 1000 & 130 & 0.03 & 1000 & 130 \\
\hline C-5-S & 6.850 & 370 & .3940 & 0300 & 8071 & 1905 & 1284 & 0052 & 0.4 & 2113 & 48 & 2120 & 140 & 2070 & 65 & 0.00 & 2070 & 65 \\
\hline$C-5-S$ & 3.780 & 00 & 0.2380 & 0.0200 & 201681 & 0.494315 & 1148 & 0.0087 & $0.3 / 735$ & 1599 & 84 & 1380 & 140 & 1810 & 120 & 0.14 & 1810 & 120 \\
\hline-5 & 3.500 & 230 & 2700 & 0200 & 4 & 218 & 0948 & 3 & 0.39834 & 1529 & 56 & 1530 & 100 & 1503 & 85 & 0.00 & 1503 & 85 \\
\hline C-5-S & 1.970 & 00 & 0.1860 & 0.0100 & 5.376344 & 0.520291 & .0760 & 0.0030 & 0.22537 & 1096 & 58 & 1091 & 87 & 1073 & 78 & .00 & 1073 & 78 \\
\hline-5 & 30 & 0.300 & 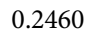 & 0.0130 & 1 & 0 & 0.1085 & 0.0092 & 0.23849 & 57 & 62 & 1413 & 67 & 1700 & 140 & 09 & 00 & 140 \\
\hline C-5-S & 3.870 & 270 & 0.2870 & 0.0280 & 3.484321 & 0.388496 & .0977 & 0.0062 & 0.65258 & 1593 & 55 & 1600 & 140 & 1580 & 120 & 0.00 & 1580 & 120 \\
\hline-5 & 1 & 0.086 & 4 & 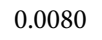 & 6 & 0 & 0.0722 & 0 & 0.47849 & 25 & 32 & 1019 & 44 & 969 & 02 & 01 & 969 & 82 \\
\hline C-5-S & 3.300 & 0.270 & 0.2640 & 0.0230 & 3.787879 & 0.387397 & .0892 & 0.0024 & 0.35049 & 1470 & 61 & 1500 & 120 & 1407 & 54 & 0.02 & 1407 & 54 \\
\hline 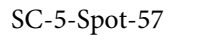 & 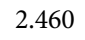 & 0.120 & 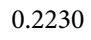 & 0.0150 & 5 & 0 & 0.0819 & 0.0031 & & 4 & 34 & 1312 & 等 & 47 & 00 & 4 & 19 & 65 \\
\hline C-5-S & 2.930 & 0.180 & 0.2060 & 0.0130 & 4.854369 & 0.377038 & 0999 & 0.0037 & 699 & 1374 & 47 & 1212 & 66 & 1608 & 70 & 0.12 & 1608 & 70 \\
\hline 5 & 200 & $=$ & 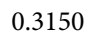 & 0.0420 & 3 & & & & & 1650 & 100 & 1740 & 200 & 1629 & 72 & 05 & 1629 & 72 \\
\hline C-5-S & 5.110 & .190 & 0.3450 & 0.0170 & 2.898551 & 0.201638 & 085 & 0.0028 & 476 & 1847 & 28 & 1915 & 81 & 1783 & 48 & .04 & 1783 & 48 \\
\hline 8 & & & 1790 & & 92 & 0. & 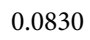 & & & 1120 & 96 & 1060 & 110 & 1200 & 170 & .05 & 1200 & 170 \\
\hline$C-5-$ & 2.420 & 0.160 & 0.1940 & 0100 & 639 & 984 & 912 & 57 & 8 & 1243 & 44 & 1140 & 55 & 1390 & 110 & .08 & 1390 & 110 \\
\hline C-5- & 20 & & 370 & & 109 & & & & & 1422 & 54 & 1361 & 96 & 1532 & 76 & .04 & 1532 & 76 \\
\hline$-5-$ & 4.050 & 0.230 & 090 & 40 & 46 & 0. & 0 & 3 & 0 & 1636 & 45 & 1730 & 120 & 1577 & 95 & .06 & 1577 & 95 \\
\hline 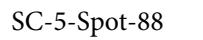 & 50 & 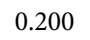 & & & & & & & & 1790 & 35 & 1828 & 79 & 1750 & 32 & 02 & 1750 & 52 \\
\hline 5 & 2 & 0.120 & 0 & 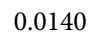 & 2 & 0 & 2 & 1 & 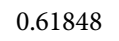 & 1214 & 35 & 1234 & 80 & 1246 & 74 & 02 & 1246 & 74 \\
\hline a & 5.100 & 00 & 100 & & 56667 & & & & & 1449 & 36 & 1388 & 72 & $155 /$ & 72 & 04 & 1557 & 72 \\
\hline SC - 5-Snot 9 & 1 & 0.560 & 0 & S & 5 & 0 & 0 & 0 & 06 & 1700 & 110 & 1280 & 110 & 2160 & 220 & .25 & ( & 1 \\
\hline $\mathrm{C}-5-$ & 2.300 & & & & 4.608295 & 0. & 788 & & & 1214 & 35 & 1263 & 61 & 1169 & 54 & 0.04 & 1169 & 54 \\
\hline 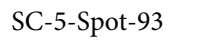 & 2 & 0.110 & & ( & 1 & 0 & & & & 1174 & 33 & 1192 & 64 & 1223 & 86 & .00 & 1223 & 86 \\
\hline$u-$ & 4.060 & 200 & 0 & O & 05 & 0 . & & & & 1639 & 38 & 1697 & 86 & 1630 & 59 & 0.04 & 1630 & 59 \\
\hline - & 2.100 & 0.140 & & ( & & 0. & & 28 & & $12 J 5$ & 43 & 1285 & 83 & 1206 & 65 & .02 & 1206 & 65 \\
\hline 90 & 80 & 0 & & & 19 & 0. & & & & 1772 & 77 & 1530 & 160 & 2110 & 110 & 0.14 & 2110 & 110 \\
\hline . & 1.100 & 200 & & 0.0270 & & & 1075 & 0.0032 & & 1721 & 52 & 1720 & 140 & 1763 & 91 & 0.00 & 1700 & 91 \\
\hline$C-5-$ & 40 & & 760 & & 23188 & 5677 & 02 & 33 & & 1576 & 39 & 1577 & 80 & 1607 & 61 & 0.00 & 1607 & 61 \\
\hline$C-5$ & $2.0+3$ & 0 & 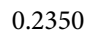 & 0 & 55319 & & .0824 & 26 & & 92 & 35 & 1356 & 69 & 1264 & 58 & .05 & 1264 & 58 \\
\hline $\mathrm{SC}-5$ & & 160 & & 10 & 10 & 0.3 & 0 & 33 & & 1272 & 46 & 1275 & 75 & 1312 & 73 & 0.00 & 1312 & 73 \\
\hline C-5- & 3.92 & 0.220 & 0.29 & 0.026 & 3.448276 & 0.356 & .1003 & 0.00 & 0.0 & 1617 & 46 & 1630 & 130 & 1617 & 97 & .01 & 1617 & 97 \\
\hline 5 & 2.240 & 0.120 & 0 & 0.0120 & 4 & 0 & 0 & 2 & & 11 & 37 & 1191 & 65 & 1167 & 79 & 01 & 1167 & 79 \\
\hline$C-5$ & 4.32 & 0.180 & 0.3010 & 0.0170 & 3.322259 & 0.253860 & 0.1066 & 0.0042 & $0.0 / 710$ & 1699 & 35 & 1686 & 84 & 1716 & 68 & 0.01 & 1716 & 68 \\
\hline & & 0.097 & & & & & 0.0798 & & & 1 & 29 & 4 & 57 & 1199 & 79 & 0 & 9 & 79 \\
\hline$U-5-5$ pot-105 & 3.400 & 190 & 2600 & .0150 & 3.846154 & 0.281065 & 0.0967 & 0.0038 & 0.48161 & 1504 & 44 & 1482 & 75 & 1545 & 73 & 0.01 & 1545 & 73 \\
\hline
\end{tabular}


Isotopic Ratios

\begin{tabular}{|c|c|c|c|c|c|c|c|c|c|c|c|c|c|c|c|c|c|}
\hline $\begin{array}{c}\text { Sample and } \\
\text { analysis number }\end{array}$ & $\begin{array}{l}{ }^{207} \mathrm{~Pb} / \\
{ }^{235} \mathrm{U}\end{array}$ & $2 \sigma$ & $\begin{array}{c}{ }^{206} \mathrm{~Pb} / \\
{ }^{238} \mathrm{U}\end{array}$ & $2 \sigma$ & $\begin{array}{l}{ }^{238} \mathrm{U} / \\
{ }^{206} \mathrm{~Pb}\end{array}$ & $2 \sigma$ & $\begin{array}{c}{ }^{207} \mathrm{~Pb} / \\
{ }^{206} \mathrm{~Pb}\end{array}$ & $2 \sigma$ & $\mathrm{EC}$ & $\begin{array}{l}{ }^{207} \mathrm{~Pb} / \\
{ }^{235} \mathrm{U}\end{array}$ & $2 \sigma$ & $\begin{array}{c}{ }^{206} \mathrm{~Pb} / \\
{ }^{238} \mathrm{U}\end{array}$ & $2 \sigma$ & $\begin{array}{l}{ }^{207} \mathrm{~Pb} / \\
{ }^{206} \mathrm{~Pb}\end{array}$ & $2 \sigma$ & Con. & $\begin{array}{l}\text { Plot } \\
\text { Age }\end{array}$ \\
\hline
\end{tabular}

$\begin{array}{llllllllll}\text { SC-5-Spot-106 } & 3.810 & 0.220 & 0.2890 & 0.0190 & 3.460208 & 0.287353 & 0.0988 & 0.0036 & 0.6318\end{array}$

$\begin{array}{llllllllll}\text { SC-5-Spot-107 } & 2.990 & 0.160 & 0.2560 & 0.0160 & 3.906250 & 0.305176 & 0.0861 & 0.0031 & 0.50667\end{array}$

$\begin{array}{llllllllll}\text { SC-5-Spot-126 } & 2.510 & 0.100 & 0.2170 & 0.0120 & 4.608295 & 0.339782 & 0.0843 & 0.0031 & 0.69041\end{array}$

$\begin{array}{llllllllll}\text { SC-5-Spot-127 } & 2.390 & 0.200 & 0.2050 & 0.0160 & 4.878049 & 0.452112 & 0.0830 & 0.0038 & 0.24287\end{array}$

$\begin{array}{llllllllll}\text { SC-5-Spot-128 } & 3.920 & 0.220 & 0.2980 & 0.0260 & 3.355705 & 0.337823 & 0.0945 & 0.0040 & 0.59843\end{array}$

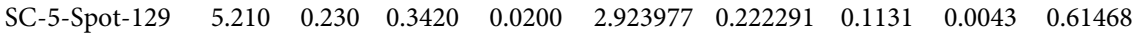

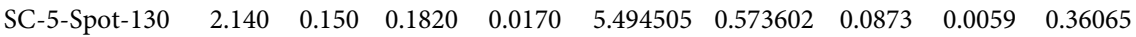

$\begin{array}{llllllllll}\text { SC-5-Spot-131 } & 4.520 & 0.580 & 0.2940 & 0.0340 & 3.401361 & 0.428062 & 0.1120 & 0.0100 & 0.53912\end{array}$

$\begin{array}{llllllllll}\text { SC-5-Spot-132 } & 3.700 & 0.170 & 0.2840 & 0.0170 & 3.521127 & 0.272763 & 0.0961 & 0.0037 & 0.7518\end{array}$

$\begin{array}{llllllllll}\text { SC-5-Spot-133 } & 2.560 & 0.140 & 0.2250 & 0.0170 & 4.444444 & 0.395062 & 0.0844 & 0.0041 & 0.68279\end{array}$

$\begin{array}{llllllllll}\text { SC-5-Spot-134 } & 2.390 & 0.130 & 0.2150 & 0.0130 & 4.651163 & 0.367766 & 0.0807 & 0.0026 & 0.45639\end{array}$

$\begin{array}{llllllllll}\text { SC-5-Spot-135 } & 3.070 & 0.250 & 0.2440 & 0.0320 & 4.098361 & 0.571083 & 0.1002 & 0.0095 & 0.77363\end{array}$

$\begin{array}{llllllllll}\text { SC-5-Spot-136 } & 3.580 & 0.480 & 0.2310 & 0.0170 & 4.329004 & 0.374806 & 0.1015 & 0.0092 & 0.037504\end{array}$

$\begin{array}{llllllllll}\text { SC-5-Spot-137 } & 3.450 & 0.230 & 0.2380 & 0.0180 & 4.201681 & 0.370737 & 0.1031 & 0.0049 & 0.43991\end{array}$

$\begin{array}{llllllllll}\text { SC-5-Spot-138 } & 4.530 & 0.270 & 0.3210 & 0.0250 & 3.115265 & 0.291146 & 0.1024 & 0.0049 & 0.62088\end{array}$

$\begin{array}{llllllllll}\text { SC-5-Spot-139 } & 2.220 & 0.110 & 0.1990 & 0.0130 & 5.025126 & 0.404030 & 0.0821 & 0.0036 & 0.6386\end{array}$

$\begin{array}{llllllllll}\text { SC-5-Spot-140 } & 2.940 & 0.180 & 0.2340 & 0.0150 & 4.273504 & 0.346994 & 0.0879 & 0.0034 & 0.54839\end{array}$

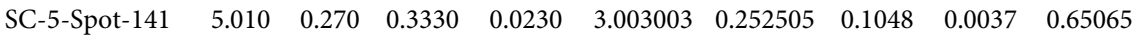

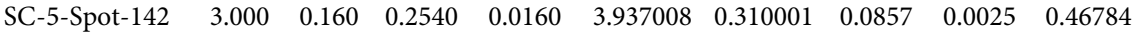

$\begin{array}{llllllllll}\text { SC-5-Spot-143 } & 2.590 & 0.130 & 0.2340 & 0.0120 & 4.273504 & 0.310468 & 0.0813 & 0.0027 & 0.65216\end{array}$

$\begin{array}{llllllllll}\text { SC-5-Spot-144 } & 3.400 & 0.300 & 0.2350 & 0.0270 & 4.255319 & 0.525125 & 0.1068 & 0.0071 & 0.68595\end{array}$

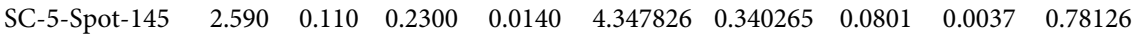

$\begin{array}{llllllllll}\text { SC-5-Spot-146 } & 2.550 & 0.220 & 0.2070 & 0.0160 & 4.830918 & 0.443418 & 0.0892 & 0.0079 & 0.54252\end{array}$

$\begin{array}{llllllllll}\text { SC-5-Spot-147 } & 3.850 & 0.190 & 0.2780 & 0.0190 & 3.597122 & 0.310543 & 0.0987 & 0.0041 & 0.72106\end{array}$

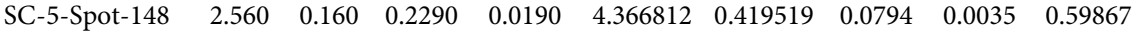

$\begin{array}{llllllllll}\text { SC-5-Spot-149 } & 2.410 & 0.110 & 0.2200 & 0.0130 & 4.545455 & 0.351240 & 0.0794 & 0.0030 & 0.70987\end{array}$

$\begin{array}{llllllllll}\text { SC-5-Spot-150 } & 2.520 & 0.130 & 0.2280 & 0.0140 & 4.385965 & 0.346260 & 0.0815 & 0.0039 & 0.61846\end{array}$

$\begin{array}{llllllllll}\text { SC-5-Spot-151 } & 6.230 & 0.280 & 0.3900 & 0.0230 & 2.564103 & 0.197239 & 0.1127 & 0.0041 & 0.6279\end{array}$

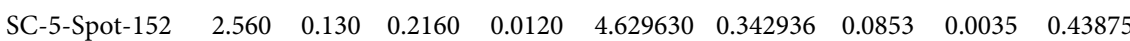

$\begin{array}{llllllllll}\text { SC-5-Spot-153 } & 2.700 & 0.160 & 0.2280 & 0.0140 & 4.385965 & 0.346260 & 0.0831 & 0.0036 & 0.42722\end{array}$

$\begin{array}{llllllllll}\text { SC-5-Spot-154 } & 3.780 & 0.170 & 0.2910 & 0.0180 & 3.436426 & 0.271608 & 0.0944 & 0.0033 & 0.66541\end{array}$

$\begin{array}{llllllllll}\text { SC-5-Spot-155 } & 3.220 & 0.220 & 0.2570 & 0.0210 & 3.891051 & 0.378507 & 0.0940 & 0.0051 & 0.39297\end{array}$

$\begin{array}{llllllllll}\text { SC-5-Spot-156 } & 2.840 & 0.170 & 0.2210 & 0.0160 & 4.524887 & 0.409492 & 0.0947 & 0.0040 & 0.59561\end{array}$

$\begin{array}{llllllllll}\text { SC-5-Spot-157 } & 3.810 & 0.170 & 0.2980 & 0.0200 & 3.355705 & 0.281519 & 0.0953 & 0.0035 & 0.76434\end{array}$

$\begin{array}{llllllllll}\text { SC-5-Spot-158 } & 2.760 & 0.160 & 0.2210 & 0.0160 & 4.524887 & 0.389017 & 0.0922 & 0.0043 & 0.59555\end{array}$

$\begin{array}{llllllllll}\text { SC-5-Spot-159 } & 2.700 & 0.130 & 0.2360 & 0.0160 & 4.237288 & 0.359092 & 0.0813 & 0.0029 & 0.77411\end{array}$

$\begin{array}{llllllllll}\text { SC-5-Spot-160 } & 5.730 & 0.230 & 0.3540 & 0.0250 & 2.824859 & 0.247375 & 0.1169 & 0.0054 & 0.82239\end{array}$

$\begin{array}{llllllllll}\text { SC-5-Spot-161 } & 3.300 & 0.360 & 0.2090 & 0.0300 & 4.784689 & 0.732584 & 0.1179 & 0.0096 & 0.35299\end{array}$

$\begin{array}{llllllllll}\text { SC-5-Spot-176 } & 3.030 & 0.140 & 0.2450 & 0.0120 & 4.081633 & 0.283215 & 0.0879 & 0.0028 & 0.2452\end{array}$

$\begin{array}{llllllllll}\text { SC-5-Spot-177 } & 6.130 & 0.510 & 0.3710 & 0.0420 & 2.695418 & 0.334203 & 0.1270 & 0.0100 & 0.66557\end{array}$

$\begin{array}{llllllllll}\text { SC-5-Spot-178 } & 2.990 & 0.140 & 0.2570 & 0.0170 & 3.891051 & 0.317946 & 0.0847 & 0.0037 & 0.64356\end{array}$ $\begin{array}{lllllllll}1593 & 44 & 1624 & 97 & 1589 & 66 & 0.02 & 1589 & 66\end{array}$

$\begin{array}{lllllllll}1400 & 40 & 1461 & 82 & 1326 & 72 & 0.04 & 1326 & 72\end{array}$

$\begin{array}{lllllllll}1272 & 28 & 1273 & 68 & 1311 & 63 & 0.00 & 1311 & 63\end{array}$

$\begin{array}{lllllllll}1212 & 53 & 1197 & 84 & 1243 & 85 & 0.01 & 1243 & 85\end{array}$

$\begin{array}{lllllllll}1613 & 48 & 1660 & 130 & 1524 & 89 & 0.03 & 1524 & 89\end{array}$

$\begin{array}{lllllllll}1866 & 40 & 1887 & 94 & 1844 & 68 & 0.01 & 1844 & 68\end{array}$

$\begin{array}{lllllllll}1155 & 48 & 1074 & 92 & 1330 & 130 & 0.07 & 1330 & 130\end{array}$

$\begin{array}{lllllllll}1700 & 100 & 1670 & 160 & 1770 & 150 & 0.02 & 1770 & 150\end{array}$

$\begin{array}{lllllllll}1571 & 39 & 1606 & 86 & 1547 & 70 & 0.02 & 1547 & 70\end{array}$

$\begin{array}{lllllllll}1283 & 40 & 1300 & 89 & 1276 & 94 & 0.01 & 1276 & 94\end{array}$

$\begin{array}{lllllllll}1243 & 36 & 1253 & 69 & 1208 & 67 & 0.01 & 1208 & 67\end{array}$

$\begin{array}{lllllllll}1403 & 64 & 1380 & 160 & 1610 & 170 & 0.02 & 1610 & 170\end{array}$

$\begin{array}{lllllllll}1488 & 97 & 1334 & 87 & 1590 & 160 & 0.10 & 1590 & 160\end{array}$

$\begin{array}{lllllllll}1505 & 51 & 1369 & 93 & 1659 & 87 & 0.09 & 1659 & 87\end{array}$

$\begin{array}{lllllllll}1724 & 49 & 1780 & 120 & 1654 & 86 & 0.03 & 1654 & 86\end{array}$

$\begin{array}{lllllllll}1187 & 36 & 1167 & 68 & 1266 & 84 & 0.02 & 1266 & 84\end{array}$

$\begin{array}{lllllllll}1386 & 47 & 1350 & 80 & 1407 & 75 & 0.03 & 1407 & 75\end{array}$

$\begin{array}{lllllllll}1818 & 46 & 1860 & 110 & 1709 & 63 & 0.02 & 1709 & 63\end{array}$

$\begin{array}{lllllllll}1419 & 43 & 1450 & 81 & 1330 & 59 & 0.02 & 1330 & 59\end{array}$

$\begin{array}{lllllllll}1289 & 37 & 1360 & 67 & 1207 & 66 & 0.06 & 1207 & 66\end{array}$

$\begin{array}{lllllllll}1493 & 64 & 1350 & 140 & 1760 & 120 & 0.10 & 1760 & 120\end{array}$

$\begin{array}{lllllllll}1294 & 31 & 1326 & 74 & 1230 & 100 & 0.02 & 1230 & 100\end{array}$

$\begin{array}{lllllllll}1271 & 58 & 1226 & 92 & 1380 & 160 & 0.04 & 1380 & 160\end{array}$

$\begin{array}{lllllllll}1602 & 38 & 1576 & 96 & 1579 & 78 & 0.02 & 1579 & 78\end{array}$

$\begin{array}{lllllllll}1291 & 46 & 1353 & 92 & 1186 & 77 & 0.05 & 1186 & 77\end{array}$

$\begin{array}{lllllllll}1242 & 31 & 1287 & 71 & 1178 & 77 & 0.04 & 1178 & 77\end{array}$

$\begin{array}{lllllllll}1275 & 35 & 1329 & 75 & 1220 & 90 & 0.04 & 1220 & 90\end{array}$

$\begin{array}{lllllllll}2007 & 40 & 2120 & 110 & 1821 & 66 & 0.06 & 1821 & 66\end{array}$

$\begin{array}{lllllllll}1281 & 36 & 1257 & 65 & 1301 & 77 & 0.02 & 1301 & 77\end{array}$

$\begin{array}{lllllllll}1320 & 45 & 1332 & 77 & 1261 & 81 & 0.01 & 1261 & 81\end{array}$

$\begin{array}{lllllllll}1582 & 36 & 1639 & 88 & 1514 & 71 & 0.04 & 1514 & 71\end{array}$

$\begin{array}{lllllllll}1477 & 63 & 1460 & 110 & 1500 & 110 & 0.01 & 1500 & 110\end{array}$

$\begin{array}{lllllllll}1358 & 44 & 1280 & 87 & 1518 & 76 & 0.06 & 1518 & 76\end{array}$

$\begin{array}{lllllllll}1592 & 34 & 1670 & 100 & 1533 & 71 & 0.05 & 1533 & 71\end{array}$

$\begin{array}{lllllllll}1335 & 43 & 1277 & 83 & 1458 & 88 & 0.04 & 1458 & 88\end{array}$

$\begin{array}{lllllllll}1334 & 35 & 1355 & 85 & 1253 & 71 & 0.02 & 1253 & 71\end{array}$

$\begin{array}{lllllllll}1942 & 34 & 1960 & 120 & 1880 & 83 & 0.01 & 1880 & 83\end{array}$

$\begin{array}{lllllllll}1464 & 85 & 1200 & 150 & 1900 & 140 & 0.18 & --- & --\end{array}$

$\begin{array}{lllllllll}1410 & 36 & 1408 & 64 & 1368 & 63 & 0.00 & 1368 & 63\end{array}$

$\begin{array}{lllllllll}1973 & 74 & 2010 & 200 & 2000 & 140 & 0.02 & 2000 & 140\end{array}$

$\begin{array}{lllllllll}1394 & 36 & 1476 & 85 & 1301 & 89 & 0.06 & 1301 & 89\end{array}$ 
Isotopic Ratios

\begin{tabular}{|c|c|c|c|c|c|c|c|c|c|c|c|c|c|c|c|c|c|}
\hline $\begin{array}{c}\text { Sample and } \\
\text { analysis number }\end{array}$ & $\begin{array}{c}{ }^{207} \mathrm{~Pb} / \\
{ }^{235} \mathrm{U}\end{array}$ & $2 \sigma$ & $\begin{array}{c}{ }^{206} \mathrm{~Pb} / \\
{ }^{238} \mathrm{U}\end{array}$ & $2 \sigma$ & $\begin{array}{l}{ }^{238} \mathrm{U} / \\
{ }^{206} \mathrm{~Pb}\end{array}$ & $2 \sigma$ & $\begin{array}{c}{ }^{207} \mathrm{~Pb} / \\
{ }^{206} \mathrm{~Pb}\end{array}$ & $2 \sigma$ & EC & $\begin{array}{c}{ }^{207} \mathrm{~Pb} / \\
{ }^{235} \mathrm{U}\end{array}$ & $2 \sigma$ & $\begin{array}{c}{ }^{206} \mathrm{~Pb} / \\
{ }^{238} \mathrm{U}\end{array}$ & $2 \sigma$ & $\begin{array}{l}{ }^{207} \mathrm{~Pb} / \\
{ }^{206} \mathrm{~Pb}\end{array}$ & & Con. & $\begin{array}{l}\text { Plot } \\
\text { Age }\end{array}$ \\
\hline
\end{tabular}

\begin{tabular}{llllllllll}
\hline SC-5-Spot-179 & 2.960 & 0.150 & 0.2430 & 0.0210 & 4.115226 & 0.423377 & 0.0915 & 0.0055 & 0.8483
\end{tabular}

$\begin{array}{lllllllllll}\text { SC-5-Spot-180 } & 6.400 & 0.360 & 0.4060 & 0.0310 & 2.463054 & 0.224466 & 0.1205 & 0.0053 & 0.68167\end{array}$

$\begin{array}{llllllllll}\text { SC-5-Spot-181 } & 1.900 & 0.150 & 0.1800 & 0.0160 & 5.555556 & 0.586420 & 0.0787 & 0.0052 & 0.69395\end{array}$

$\begin{array}{llllllllll}\text { SC-5-Spot-182 } & 3.610 & 0.200 & 0.2840 & 0.0200 & 3.521127 & 0.297560 & 0.0945 & 0.0037 & 0.50022\end{array}$

$\begin{array}{lllllllllll}\text { SC-5-Spot-183 } & 2.410 & 0.180 & 0.1940 & 0.0180 & 5.154639 & 0.531406 & 0.0938 & 0.0084 & 0.61457\end{array}$

$\begin{array}{llllllllll}\text { SC-5-Spot-184 } & 2.120 & 0.140 & 0.1920 & 0.0140 & 5.208333 & 0.461155 & 0.0834 & 0.0052 & 0.559\end{array}$

$\begin{array}{llllllllll}\text { SC-5-Spot-185 } & 3.490 & 0.240 & 0.2690 & 0.0280 & 3.717472 & 0.428408 & 0.0973 & 0.0075 & 0.81417\end{array}$

$\begin{array}{lllllllllll}\text { SC-5-Spot-186 } & 3.460 & 0.190 & 0.2500 & 0.0190 & 4.000000 & 0.352000 & 0.0978 & 0.0044 & 0.78395\end{array}$

$\begin{array}{llllllllll}\text { SC-5-Spot-187 } & 1.770 & 0.160 & 0.1770 & 0.0180 & 5.649718 & 0.638386 & 0.0788 & 0.0072 & 0.60761\end{array}$

$\begin{array}{llllllllll}\text { SC-5-Spot-188 } & 3.160 & 0.240 & 0.2540 & 0.0230 & 3.937008 & 0.418501 & 0.0878 & 0.0041 & 0.6021\end{array}$

$\begin{array}{llllllllll}\text { SC-5-Spot-189 } & 5.210 & 0.260 & 0.3180 & 0.0240 & 3.144654 & 0.286777 & 0.1225 & 0.0047 & 0.78597\end{array}$

$\begin{array}{llllllllll}\text { SC-5-Spot-190 } & 1.720 & 0.140 & 0.1730 & 0.0110 & 5.780347 & 0.467774 & 0.0714 & 0.0062 & 0.5493\end{array}$

$\begin{array}{llllllllll}\text { SC-5-Spot-191 } & 3.830 & 0.440 & 0.3070 & 0.0440 & 3.257329 & 0.488069 & 0.0926 & 0.0059 & 0.77803\end{array}$

$\begin{array}{lllllllllll}\text { SC-5-Spot-192 } & 3.100 & 0.180 & 0.2450 & 0.0210 & 4.081633 & 0.399833 & 0.0943 & 0.0044 & 0.61172\end{array}$

$\begin{array}{llllllllll}\text { SC-5-Spot-193 } & 2.900 & 0.220 & 0.2290 & 0.0210 & 4.366812 & 0.457657 & 0.0912 & 0.0045 & 0.4889\end{array}$

$\begin{array}{llllllllll}\text { SC-5-Spot-194 } & 2.560 & 0.170 & 0.2190 & 0.0150 & 4.566210 & 0.396155 & 0.0851 & 0.0037 & 0.56514\end{array}$

$\begin{array}{llllllllll}\text { SC-5-Spot-195 } & 2.460 & 0.130 & 0.2150 & 0.0160 & 4.651163 & 0.411033 & 0.0829 & 0.0033 & 0.73859\end{array}$

$\begin{array}{llllllllll}\text { SC-5-Spot-196 } & 6.000 & 0.300 & 0.3240 & 0.0200 & 3.086420 & 0.247676 & 0.1310 & 0.0056 & 0.7359\end{array}$

$\begin{array}{llllllllll}\text { SC-5-Spot-197 } & 2.530 & 0.300 & 0.1980 & 0.0220 & 5.050505 & 0.612182 & 0.0845 & 0.0066 & 0.08557\end{array}$

$\begin{array}{llllllllll}\text { SC-5-Spot-199 } & 2.730 & 0.340 & 0.2640 & 0.0400 & 3.787879 & 0.602617 & 0.0815 & 0.0063 & 0.84247\end{array}$

$\begin{array}{llllllllll}\text { SC-5-Spot-200 } & 3.710 & 0.190 & 0.2870 & 0.0210 & 3.484321 & 0.315653 & 0.0943 & 0.0034 & 0.62029\end{array}$

$\begin{array}{llllllllll}\text { SC-5-Spot-202 } & 3.040 & 0.230 & 0.2080 & 0.0140 & 4.807692 & 0.392936 & 0.1063 & 0.0084 & 0.44404\end{array}$

$\begin{array}{lllllllllll}\text { SC-5-Spot-204 } & 3.640 & 0.190 & 0.2690 & 0.0210 & 3.717472 & 0.345490 & 0.0980 & 0.0045 & 0.81365\end{array}$

$\begin{array}{llllllllll}\text { SC-5-Spot-206 } & 2.290 & 0.120 & 0.1980 & 0.0160 & 5.050505 & 0.484644 & 0.0818 & 0.0030 & 0.61159\end{array}$

$\begin{array}{llllllllll}\text { SC-5-Spot-208 } & 3.760 & 0.240 & 0.2520 & 0.0240 & 3.968254 & 0.425170 & 0.1061 & 0.0075 & 0.78367\end{array}$

Sample SC-6: Appleton Ridge Formation of the Fredericton Trough

$\begin{array}{lllllllllll}\text { SC-6-Spot-1 } & 0.686 & 0.025 & 0.0849 & 0.0039 & 11.778560 & 0.541065 & 0.0582 & 0.0023 & 0.64004\end{array}$

$\begin{array}{lllllllllll}\text { SC-6-Spot-2 } & 1.660 & 0.280 & 0.0806 & 0.0041 & 12.406950 & 0.631123 & 0.1410 & 0.0210 & -0.30658\end{array}$

$\begin{array}{llllllllll}\text { SC-6-Spot-3 } & 0.906 & 0.059 & 0.0853 & 0.0050 & 11.723330 & 0.687182 & 0.0787 & 0.0068 & 0.79302\end{array}$

$\begin{array}{llllllllll}\text { SC-6-Spot-4 } & 0.791 & 0.093 & 0.0842 & 0.0035 & 11.876480 & 0.493678 & 0.0719 & 0.0093 & 0.14051\end{array}$

$\begin{array}{lllllllllll}\text { SC-6-Spot-5 } & 0.726 & 0.043 & 0.0859 & 0.0045 & 11.641440 & 0.609854 & 0.0613 & 0.0031 & 0.22073\end{array}$

$\begin{array}{llllllllll}\text { SC-6-Spot-6 } & 0.832 & 0.035 & 0.0972 & 0.0038 & 10.288070 & 0.402208 & 0.0621 & 0.0020 & 0.45007\end{array}$

$\begin{array}{llllllllll}\text { SC-6-Spot-7 } & 0.736 & 0.033 & 0.0807 & 0.0033 & 12.391570 & 0.506719 & 0.0644 & 0.0027 & 0.50381\end{array}$

$\begin{array}{lllllllllll}\text { SC-6-Spot-8 } & 3.100 & 0.094 & 0.2310 & 0.0110 & 4.329004 & 0.206143 & 0.0954 & 0.0029 & 0.74674\end{array}$

$\begin{array}{llllllllll}\text { SC-6-Spot-36 } & 0.777 & 0.043 & 0.0887 & 0.0050 & 11.273960 & 0.635511 & 0.0644 & 0.0040 & 0.14686\end{array}$

$\begin{array}{llllllllll}\text { SC-6-Spot-37 } & 0.960 & 0.130 & 0.0890 & 0.0037 & 11.235960 & 0.467113 & 0.0766 & 0.0073 & -0.33134\end{array}$

$\begin{array}{lllllllllll}\text { SC-6-Spot-38 } & 0.759 & 0.042 & 0.0900 & 0.0046 & 11.111110 & 0.567901 & 0.0619 & 0.0025 & 0.36570\end{array}$

$\begin{array}{llllllllll}\text { SC-6-Spot-39 } & 0.841 & 0.042 & 0.0822 & 0.0045 & 12.165450 & 0.665992 & 0.0741 & 0.0042 & 0.48348\end{array}$

$\begin{array}{llllllllll}\text { SC-6-Spot-40 } & 1.162 & 0.040 & 0.1280 & 0.0046 & 7.812500 & 0.280762 & 0.0656 & 0.0018 & 0.47651\end{array}$

$\begin{array}{lllllllllll}\text { SC-6-Spot-42 } & 1.571 & 0.069 & 0.1596 & 0.0074 & 6.265664 & 0.290513 & 0.0720 & 0.0040 & 0.73921\end{array}$

$\begin{array}{llllllllll}\text { SC-6-Spot-43 } & 3.670 & 0.140 & 0.2650 & 0.0160 & 3.773585 & 0.227839 & 0.1001 & 0.0034 & 0.76196\end{array}$ $\begin{array}{lllllllll}1392 & 38 & 1400 & 110 & 1470 & 120 & 0.01 & 1470 & 120\end{array}$

$\begin{array}{lllllllll}2020 & 50 & 2170 & 140 & 1930 & 80 & 0.07 & 1930 & 80\end{array}$

$\begin{array}{lllllllll}1072 & 49 & 1076 & 86 & 1150 & 120 & 0.00 & 1150 & 120\end{array}$

$\begin{array}{lllllllll}1544 & 47 & 1598 & 99 & 1502 & 72 & 0.03 & 1502 & 72\end{array}$

$\begin{array}{lllllllll}1228 & 53 & 1136 & 94 & 1430 & 160 & 0.07 & 1430 & 160\end{array}$

$\begin{array}{lllllllll}1140 & 44 & 1136 & 71 & 1290 & 120 & 0.00 & 1290 & 120\end{array}$

$\begin{array}{lllllllll}1517 & 53 & 1520 & 140 & 1550 & 140 & 0.00 & 1550 & 140\end{array}$

$\begin{array}{lllllllll}1515 & 41 & 1429 & 96 & 1592 & 74 & 0.06 & 1592 & 74\end{array}$

$\begin{array}{lllllllll}1045 & 56 & 1045 & 99 & 1120 & 170 & 0.00 & 1120 & 170\end{array}$

$\begin{array}{lllllllll}1439 & 61 & 1450 & 120 & 1410 & 100 & 0.01 & 1410 & 100\end{array}$

$\begin{array}{lllllllll}1854 & 40 & 1760 & 120 & 1982 & 67 & 0.05 & 1982 & 67\end{array}$

$\begin{array}{lllllllll}1007 & 51 & 1025 & 60 & 960 & 170 & 0.02 & 960 & 170\end{array}$

$\begin{array}{lllllllll}1620 & 110 & 1700 & 220 & 1520 & 130 & 0.05 & 1520 & 130\end{array}$

$\begin{array}{lllllllll}1432 & 50 & 1400 & 100 & 1476 & 87 & 0.02 & 1476 & 87\end{array}$

$\begin{array}{lllllllll}1393 & 55 & 1320 & 110 & 1472 & 92 & 0.05 & 1472 & 92\end{array}$

$\begin{array}{lllllllll}1281 & 50 & 1272 & 81 & 1343 & 87 & 0.01 & 1343 & 87\end{array}$

$\begin{array}{llllllllll}1257 & 38 & 1249 & 84 & 1261 & 77 & 0.01 & 1261 & 77\end{array}$

$\begin{array}{lllllllll}1968 & 42 & 1816 & 95 & 2082 & 73 & 0.08 & 2082 & 73\end{array}$

$\begin{array}{lllllllll}1257 & 79 & 1150 & 120 & 1290 & 130 & 0.09 & 1290 & 130\end{array}$

$\begin{array}{llllllllll}1294 & 89 & 1480 & 200 & 1150 & 160 & 0.14 & 1150 & 160\end{array}$

$\begin{array}{lllllllll}1572 & 42 & 1610 & 100 & 1512 & 65 & 0.02 & 1512 & 65\end{array}$

$\begin{array}{lllllllll}1411 & 55 & 1214 & 72 & 1680 & 140 & 0.14 & 1680 & 140\end{array}$

$\begin{array}{lllllllll}1547 & 41 & 1520 & 110 & 1549 & 86 & 0.02 & 1549 & 86\end{array}$

$\begin{array}{lllllllll}1211 & 36 & 1157 & 84 & 1234 & 77 & 0.04 & 1234 & 77\end{array}$

$\begin{array}{lllllllll}1593 & 52 & 1460 & 130 & 1670 & 120 & 0.08 & 1670 & 120\end{array}$

$\begin{array}{lllllllll}534 & 14 & 525 & 23 & 521 & 85 & 0.02 & 525 & 23\end{array}$

$\begin{array}{lllllllll}940 & 110 & 499 & 24 & 1980 & 310 & 0.88 & --- & ---\end{array}$

$\begin{array}{lllllllll}655 & 30 & 527 & 29 & 1070 & 170 & 0.24 & --- & ---\end{array}$

$\begin{array}{lllllllll}579 & 45 & 521 & 21 & 810 & 190 & 0.11 & 521 & 21\end{array}$

$\begin{array}{lllllllll}552 & 25 & 531 & 27 & 620 & 110 & 0.04 & 531 & 27\end{array}$

$\begin{array}{lllllllll}612 & 20 & 597 & 23 & 679 & 70 & 0.03 & 597 & 23\end{array}$

$\begin{array}{lllllllll}558 & 19 & 500 & 20 & 725 & 87 & 0.12 & 500 & 20\end{array}$

$\begin{array}{lllllllll}1433 & 24 & 1337 & 58 & 1522 & 56 & 0.07 & 1522 & 56\end{array}$

$\begin{array}{lllllllll}580 & 24 & 547 & 29 & 670 & 110 & 0.06 & 547 & 29\end{array}$

$\begin{array}{lllllllll}638 & 44 & 553 & 21 & 990 & 170 & 0.15 & --- & ---\end{array}$

$\begin{array}{lllllllll}585 & 25 & 555 & 27 & 652 & 90 & 0.05 & 555 & 27\end{array}$

$\begin{array}{lllllllll}617 & 24 & 513 & 28 & 1050 & 120 & 0.20 & --- & --\end{array}$

$\begin{array}{lllllllll}781 & 19 & 776 & 26 & 779 & 58 & 0.01 & 776 & 26\end{array}$

$\begin{array}{lllllllll}959 & 27 & 953 & 41 & 980 & 110 & 0.01 & 953 & 41\end{array}$

$\begin{array}{lllllllll}1570 & 28 & 1507 & 81 & 1642 & 65 & 0.04 & 1642 & 65\end{array}$ 
Appendix B. Continued.

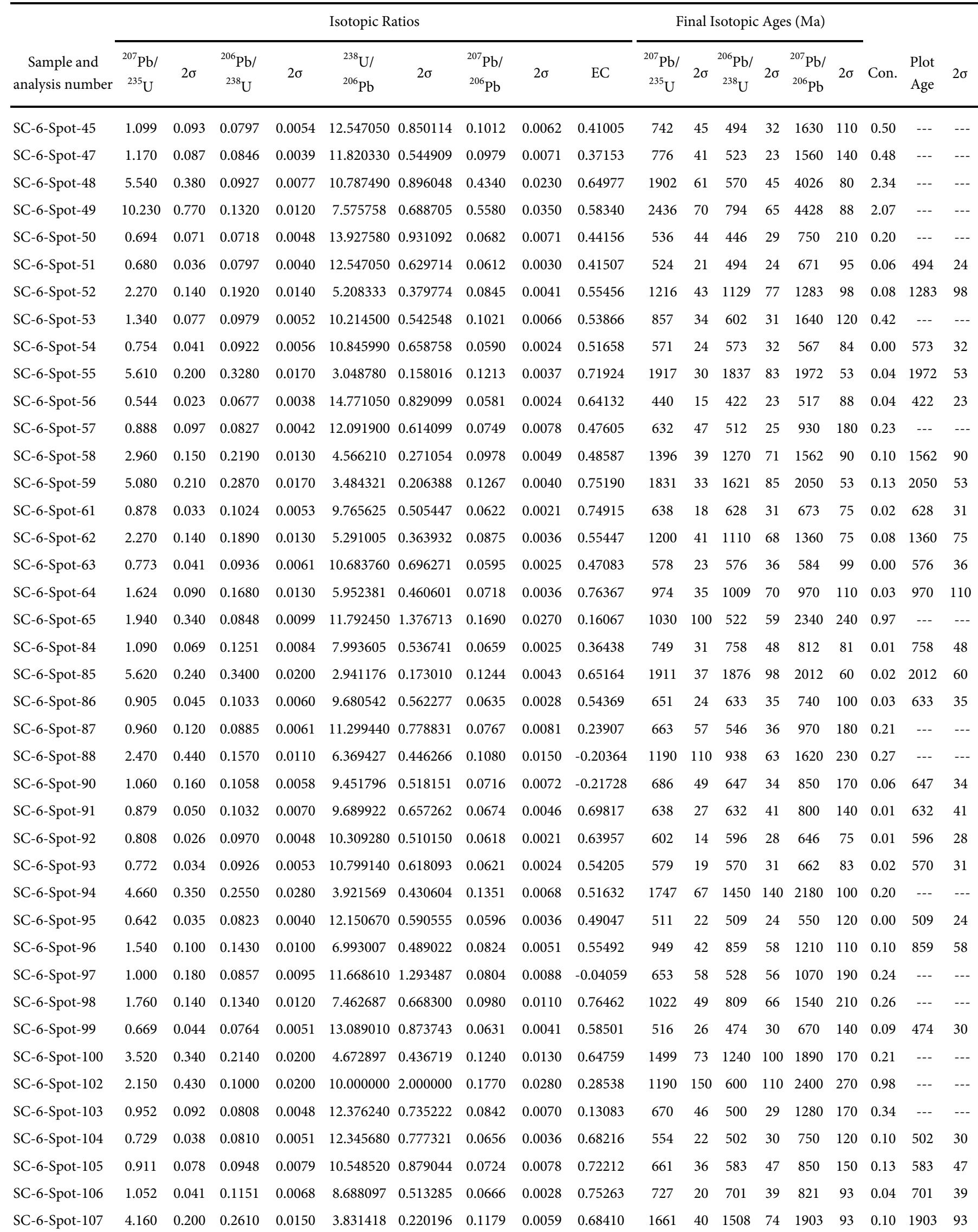


Appendix B. Continued.

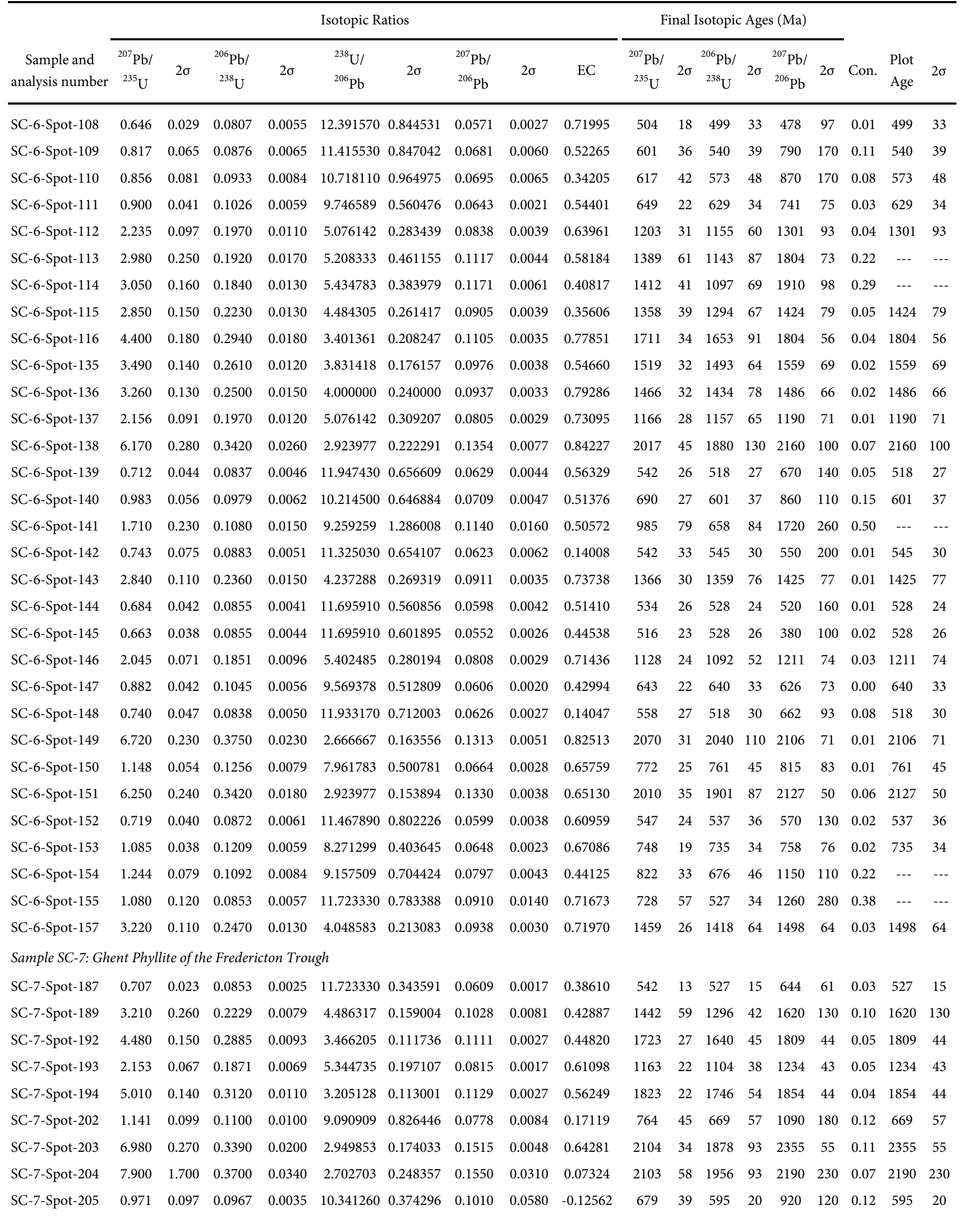


Appendix B. Continued.

\begin{tabular}{|c|c|c|c|c|c|c|c|c|c|c|c|c|c|c|c|c|c|c|}
\hline $\begin{array}{l}\text { Sample and } \\
\text { analysis number }\end{array}$ & \multicolumn{9}{|c|}{ Isotopic Ratios } & \multicolumn{6}{|c|}{ Final Isotopic Ages (Ma) } & Con. & $\begin{array}{l}\text { Plot } \\
\text { Age }\end{array}$ & $2 \sigma$ \\
\hline SC-7-Spot-206 & 5.590 & 330 & 2610 & 0200 & 18 & 0.293595 & 1590 & 0.0120 & 72997 & 1939 & 55 & 1490 & 110 & 2400 & 120 & 0.23 & -- & -- \\
\hline SC-7-Spot-207 & 0.645 & 5 & 8 & 3 & 40 & 05465 & 1 & 4 & 0.51089 & 4 & 6 & 1 & 0 & 37 & 56 & 0.01 & 1 & 0 \\
\hline SC-7-Spot-228 & 5.610 & 30 & 0.3050 & 0.0240 & 39 & 0.257995 & 6 & 6 & 23 & 1909 & 3 & 1710 & 120 & 2133 & 83 & 0.10 & 2133 & 3 \\
\hline$t-229$ & 0.843 & 072 & 0980 & 0050 & 10.204080 & 0.520616 & 063 & 0.0041 & 0.00816 & 602 & 24 & 602 & 30 & 590 & 120 & 0.00 & 602 & 30 \\
\hline SC-7-Spot-230 & 1.404 & 0.054 & 0.0783 & 0.0033 & 12.771390 & 0.538258 & 0.1321 & 0.0046 & 0.06553 & 888 & 3 & 485 & 20 & 112 & 59 & 0.45 & - & -- \\
\hline SC-7- & 0.755 & 046 & 8813 & 040 & 12.3 & 0.605172 & 0.0661 & 035 & 0.07612 & 568 & 26 & 503 & 24 & 770 & 110 & 0.11 & 503 & 24 \\
\hline SC-7-Spot-232 & 1.934 & 0.083 & 0.1744 & 0.0074 & 5.733945 & 0.243298 & 0.0820 & 0.0031 & 0.30652 & 1094 & 29 & 1035 & 41 & 1224 & 71 & 0.05 & 1224 & 71 \\
\hline SC-7-Spot-237 & 1.624 & 0.061 & 0.1580 & 0.0081 & 6.329114 & 0.324467 & 0.0748 & 0.0023 & 0.71521 & 976 & 23 & 944 & 45 & 1071 & 56 & 0.03 & 944 & 45 \\
\hline SC-7- & 0.671 & 051 & 0882 & 041 & 11. & 0.527044 & 7 & 39 & 0.00836 & 18 & 31 & 44 & 24 & 60 & 150 & 0.05 & 44 & 4 \\
\hline SC-7-Spot-239 & 5.800 & 0.190 & 0.3230 & 0.0150 & 3.095975 & 0.143776 & 0.1293 & 0.0041 & 0.6988 & 1946 & 29 & 1798 & 72 & 2075 & 55 & 0.08 & 2075 & 55 \\
\hline SC-7-S & 1.390 & 0.084 & 1082 & 54 & 14 & 253 & 3 & 55 & 0.44948 & 878 & 5 & 661 & 31 & 390 & 110 & 0.25 & --- & -- \\
\hline SC-7-Spot-241 & 0.768 & 0.046 & 00880 & 0.0042 & 11.363640 & 0.542355 & 0.0617 & 0.0033 & 017334 & 569 & 21 & 543 & 25 & 630 & 100 & 0.05 & 543 & 25 \\
\hline SC-7-S & .730 & 0.640 & 4500 & 240 & 22 & 0.118519 & 19 & 70 & $\delta$ & 2503 & 51 & 2390 & 110 & 2576 & 73 & 0.05 & 2576 & 73 \\
\hline SC-7-Spot-242 & 1.730 & 0.410 & 01062 & 0.0070 & 9.416196 & 0.620653 & 0.1120 & 0.0200 & -043190 & 900 & 110 & 649 & 41 & 1550 & 310 & 0.28 & $\ldots$ & - \\
\hline SC-7-Spot-244 & 8.000 & 2.100 & 0.3050 & 0.0330 & 3.278689 & 0.354743 & 0.1630 & 0.0240 & 0.50413 & 2080 & 130 & 1700 & 160 & 2400 & 190 & 0.18 & --- & - \\
\hline SC- & 4. & 0 & 0.2980 & 0.0130 & 5 & 0 & 2 & 0.0027 & 0.68967 & 1739 & 4 & 1679 & 65 & 4 & 4 & 03 & 794 & 44 \\
\hline SC-7-Spot-252 & 0.765 & 0.028 & 0.0903 & 0.0050 & 11.074200 & 0.613189 & 0.0618 & 0.0024 & 0.72474 & 575 & 16 & 556 & 29 & 672 & 82 & 0.03 & 556 & 29 \\
\hline $\mathrm{SC}-7$ & 2. & 0.099 & 0.1773 & 0.0099 & 8 & 3 & 0.0835 & 0.0035 & 0.52882 & 1128 & 32 & 1050 & 4 & 09 & 7 & 0.08 & 99 & 7 \\
\hline SC-7-Spot-254 & 0.643 & 0.033 & 0.0789 & 0.0044 & 12.674270 & 0.706804 & 0.0592 & 0.0025 & 0.54144 & 502 & 20 & 489 & 26 & 545 & 90 & 0.03 & 489 & 26 \\
\hline SC- & 1 . & 0 & 0.0956 & 0.0043 & 10 & 0 . & 4 & 9 & -0.07373 & 736 & 58 & 8 & 5 & 70 & 90 & 0.20 & --- & --- \\
\hline SC-7-Spot-256 & 1.186 & 0.082 & 0.0765 & 0.0038 & 13.071900 & 0.649323 & 0.1123 & 0.0069 & 0.45207 & 786 & 38 & 475 & 23 & 1830 & 110 & 0.40 & --- & --- \\
\hline SC- & 0 . & 0 & 2 & 56 & 10 & 28 & 50 & 9 & -0.27025 & 3 & 61 & 7 & 3 & 30 & 190 & 0.11 & 597 & 33 \\
\hline SC-7-S & 2.770 & 0.098 & 02028 & 0.0098 & 4.488330 & 0.197422 & 0.0891 & 0.0027 & 605 & 1344 & 27 & 1305 & 55 & 1405 & 61 & 0.03 & 1405 & 61 \\
\hline SC-7 & 1.210 & 0.260 & 0.0918 & 42 & 10. & 0.498384 & 910 & 40 & 15 & 713 & 49 & 565 & 25 & 1210 & 160 & 0.21 & --- & --- \\
\hline SC-7-S & 0.750 & 0.120 & 00785 & 54 & 12.738850 & 0.8 & 2 & 55 & 0.04842 & 554 & 58 & 487 & 32 & 650 & 150 & 0.12 & 487 & 32 \\
\hline SC-7-Spot-278 & 0.676 & 0.030 & 0.0796 & 0.0024 & 12.562810 & 0.378778 & 0.0599 & 0.0022 & 360 & 529 & 17 & 494 & 14 & 591 & 81 & 0.07 & 494 & 14 \\
\hline SC-7 & 3 & 0 & 2050 & 0 & .878049 & 1 & 0 & 0 & 0.61262 & 1540 & 110 & 1197 & 89 & 1920 & 200 & 0.22 & --- & --- \\
\hline SC-7-Spot-280 & 1.750 & 0.160 & 0.0953 & 0.0044 & 10.493180 & 0.484470 & 0.1360 & 0.0100 & -0.01035 & 1007 & 59 & 586 & 26 & 2160 & 120 & 0.42 & --- & --- \\
\hline SC-7-Spot-282 & 0.78 & 0.140 & $000 J$ & 0.0058 & 12.453300 & 399491 & 00 & 9 & -0.500 & 572 & 66 & 8 & 34 & 10 & 200 & 13 & 98 & 34 \\
\hline SC-7-Spot-283 & 10.190 & 0.390 & 0.4220 & 0.0270 & 2.369668 & 0.151614 & 0.1756 & 0.0073 & 0.86884 & 2448 & 36 & 2260 & 120 & 2598 & 69 & 0.08 & 2598 & 69 \\
\hline oot-284 & 2.210 & 0.650 & 1340 & 0.0190 & 7.462687 & 1.058142 & 0.1140 & 0.0240 & -0.03652 & 1070 & 170 & 800 & 110 & 1570 & 330 & 0.25 & - & \\
\hline
\end{tabular}


Appendix B. Continued.

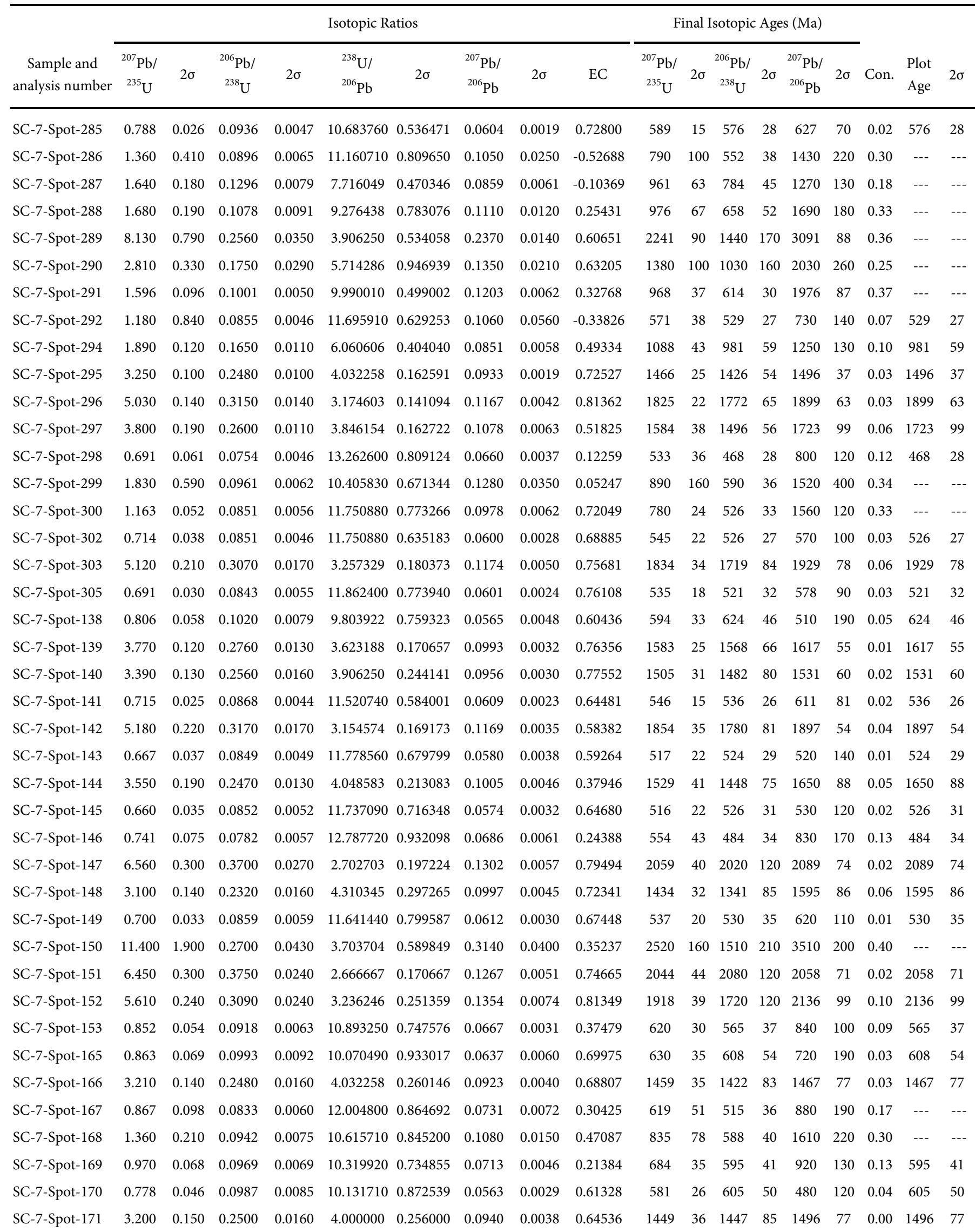


Appendix B. Continued.

\begin{tabular}{|c|c|c|c|c|c|c|c|c|c|c|c|c|c|c|c|c|c|c|}
\hline $\begin{array}{l}\text { Sample and } \\
\text { analysis number }\end{array}$ & \multicolumn{9}{|c|}{ Isotopic Ratios } & \multicolumn{6}{|c|}{ Final Isotopic Ages (Ma) } & Con. & $\begin{array}{l}\text { Plot } \\
\text { Age }\end{array}$ & $2 \sigma$ \\
\hline C-7-Spot-172 & 1.980 & 0.300 & 1030 & 0.0110 & 708738 & 1.036856 & 1310 & 0.0150 & 0.06611 & 1050 & 100 & 631 & 65 & 1960 & 220 & 0.40 & - & $\ldots$ \\
\hline SC-7-Spot-173 & 0.756 & 0.053 & 0.0940 & 0.0074 & 10.638300 & 0.837483 & 0.0588 & 0.0034 & 0.53982 & 567 & 30 & 578 & 44 & 530 & 120 & 0.02 & 578 & 44 \\
\hline SC-7-Spot-175 & 0.825 & 0.025 & 0.0976 & 0.0046 & 10.245900 & 0.482901 & 0.0602 & 0.0023 & 0.77572 & 609 & 14 & 600 & 27 & 584 & 83 & 0.01 & 600 & 27 \\
\hline SC-7-Spot-176 & 0.555 & 0.034 & 0.0699 & 0.0053 & 14.306150 & 1.084730 & 0.078 & 0.0033 & 0.64039 & 740 & 22 & 435 & 32 & 490 & 120 & 0.02 & 435 & 32 \\
\hline SC-7-Spot-177 & 0.978 & 0.074 & 0.1018 & 0.0079 & 9.823183 & 0.762310 & 0.0708 & 0.0043 & 0.46120 & 698 & 40 & 623 & 46 & 930 & 140 & 0.11 & 623 & 46 \\
\hline SC-7-Spot-178 & 0.701 & 0.054 & 0.0836 & 0.0045 & 11.961720 & 0.643873 & 0.0593 & 0.0043 & 0.28028 & 539 & 34 & 517 & 27 & 570 & 160 & 0.04 & 517 & 27 \\
\hline SC-7-Spot-179 & 2.440 & 0.590 & 0.1050 & 0.0110 & 9.523810 & 0.997732 & 0.1510 & 0.0320 & 0.09983 & 1180 & 180 & 640 & 65 & 2200 & 430 & 0.46 & --- & --- \\
\hline SC-7-Spot-198 & 0.699 & 0.042 & 0.0865 & 0.0059 & 11.560690 & 0.788533 & 0.0594 & 0.0036 & 0.50757 & (34J & 23 & (5) & 36 & 560 & 140 & 0.01 & 539 & 36 \\
\hline SC-7-Spot-199 & 2.810 & 0.150 & 0.2040 & 0.0120 & 4.901961 & 0.288351 & 0.1016 & 0.0057 & 519 & 1357 & 39 & 1192 & 65 & 1660 & 110 & 0.12 & 1660 & 110 \\
\hline SC-7-Spot-200 & 6.060 & 0.350 & 0.3320 & 0.0300 & 3.012048 & 0.272173 & 0.1350 & 0.0067 & 0.74655 & 1972 & 51 & 1830 & 140 & 2169 & 93 & 0.07 & 2169 & 93 \\
\hline SC-7-Spot-201 & 0.888 & 0.057 & 0.1044 & 0.0088 & 9.578544 & 0.807387 & .0600 & 0.0029 & 0.69819 & 645 & 30 & 638 & 51 & 580 & 110 & 0.01 & 638 & 51 \\
\hline SC-7-Spot-202 & 4.510 & 0.280 & 0.2910 & 0.0250 & 3.436426 & 0.295226 & 0.1109 & 0.0061 & 0.63799 & 1719 & 52 & 1640 & 120 & 1810 & 100 & 0.05 & 1810 & 100 \\
\hline$S C-7-S$ & 0.740 & 0.047 & 0.0877 & 0.0057 & 11.402510 & 0.741098 & 0.0623 & 0.0042 & 0. & 558 & 27 & 541 & 34 & 630 & 140 & 0.03 & 541 & 34 \\
\hline SC-7-Spot-204 & 0.675 & 0.042 & 0.0876 & 0.0074 & 11.415530 & 0.964325 & 0.0599 & 0.0038 & 0.57666 & 526 & 27 & 539 & 43 & 530 & 130 & 0.02 & 539 & 43 \\
\hline SC-7-Spot-205 & 6.590 & 0.420 & 0.3680 & 0.0280 & 7391 & 6758 & 306 & 0.0053 & 0.6 & 2042 & 54 & 2010 & 130 & 2112 & 68 & 0.02 & 2112 & 68 \\
\hline SC-7-Spot-206 & 2.730 & 0.520 & 0.1180 & 0.0160 & 8.474576 & 1.149095 & 0.1680 & 0.0250 & 0.54704 & 1260 & 150 & 709 & 92 & 2230 & 330 & 0.44 & --- & --- \\
\hline C-7-Spot-213 & 0.822 & .043 & 0.1016 & 0.0070 & 9.842520 & 0.678126 & 0.0600 & 0.0031 & 0.66233 & . & 25 & 622 & 41 & 580 & 110 & 0.02 & 622 & 41 \\
\hline SC-7-Spot-214 & 2.930 & 0.370 & 0.1041 & 0.0092 & 9.606148 & 0.848958 & 0.2030 & 0.0150 & -0.13716 & 1347 & 99 & 636 & 54 & 2810 & 130 & 0.53 & --- & --- \\
\hline SC-7-Spot-215 & 2.960 & 0.170 & 0.2310 & 0.0150 & 4.329004 & 0.281104 & م007 & 0.0029 & 0.41701 & 1400 & 44 & 1336 & 78 & 1403 & 64 & 0.05 & 1403 & 64 \\
\hline SC-7-Spot-216 & 0.711 & 0.060 & 0.0869 & 0.0084 & 11.507480 & 1.112346 & 0.0601 & 0.0041 & 0.45342 & 39 & 35 & 535 & 50 & 570 & 140 & 0.01 & 535 & 50 \\
\hline SC-7-Spot-217 & 7.030 & 0.350 & 0.3730 & 0.0230 & 2.680965 & 0.165314 & 0.1384 & 0.0054 & 0.53131 & 2130 & 43 & 2030 & 110 & 2219 & 60 & 0.05 & 2219 & 60 \\
\hline SC-7-Spot-218 & 5.110 & 0.250 & 0.3260 & 0.0210 & 3.067485 & 0.197599 & 0.1149 & 0.0038 & 0.62802 & 1834 & 41 & 1824 & 99 & 1863 & 61 & 0.01 & 1863 & 61 \\
\hline SC-7-Spot-219 & 0.658 & 0.058 & 0.0833 & 0.0058 & 12.004800 & 0.835869 & 0.0583 & 0.0037 & 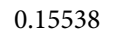 & 513 & 34 & 515 & 35 & 490 & 130 & 0.00 & 515 & 35 \\
\hline SC-7-Spot-220 & 2.100 & 0.140 & 0.2000 & 0.0160 & 5.000000 & 0.400000 & 0.0779 & 0.0036 & 0.53515 & 1161 & 44 & 1172 & 83 & 1134 & 89 & 0.01 & 1134 & 89 \\
\hline SC-7-Spot-221 & 3.410 & 0.170 & 0.2610 & 0.0190 & 3.831418 & 0.278916 & 0.0968 & 0.0032 & 506 & 1506 & 37 & 1486 & 96 & 1558 & 63 & 0.01 & 1558 & 63 \\
\hline SC-7-Spot-222 & 4.640 & 0.290 & 0.3130 & 0.0250 & 3.194888 & 0.255183 & 0.1091 & 0.0046 & 0.59259 & 1753 & 49 & 1770 & 130 & 1763 & 77 & 0.01 & 1763 & 77 \\
\hline SC-7-Spot-223 & 7.230 & 0.500 & 0.4090 & 0.0290 & 2.444988 & 0.173361 & 0.1301 & 0.0032 & 0.34126 & 2132 & 60 & 2190 & 130 & 2092 & 43 & 0.03 & 2092 & 43 \\
\hline SC-7-Spot-224 & 0.612 & 0.044 & 0.0775 & 0.0059 & 12.903230 & 0.982310 & 0.0579 & 0.0023 & 0.23737 & 481 & 28 & 480 & 35 & 499 & 88 & 0.00 & 480 & 35 \\
\hline SC-7-Spot-225 & 1.188 & 0.083 & 0.1303 & 0.0099 & 7.674597 & 0.583105 & 0.0663 & 0.0035 & 0.37428 & 793 & 41 & 787 & 56 & 810 & 110 & 0.01 & 787 & 56 \\
\hline SC-7-Spot-226 & 0.784 & 0.046 & 0.0907 & 0.0058 & 11.025360 & 0.705040 & 0.0603 & 0.0029 & 0.43541 & 584 & 27 & 559 & 34 & 615 & 99 & 0.04 & 559 & 34 \\
\hline SC-7-Spot-228 & 0.903 & 0.096 & 0.1020 & 0.0082 & 9.803922 & 0.788158 & 0.0635 & 0.0050 & 0.00734 & 640 & 50 & 624 & 48 & 680 & 170 & 0.03 & 624 & 48 \\
\hline SC-7-Spot-247 & 0.898 & 0.059 & 0.1075 & 0.0089 & 9.302326 & 0.770146 & 0.0610 & 0.0025 & 0.46657 & 645 & 32 & 656 & 52 & 636 & 91 & 0.02 & 656 & 52 \\
\hline
\end{tabular}


Appendix B. Continued.

\begin{tabular}{|c|c|c|c|c|c|c|c|c|c|c|c|c|c|c|c|c|c|c|}
\hline $\begin{array}{c}\text { Sample and } \\
\text { analysis number }\end{array}$ & \multicolumn{9}{|c|}{ Isotopic Ratios } & \multicolumn{6}{|c|}{ Final Isotopic Ages (Ma) } & Con. & $\begin{array}{l}\text { Plot } \\
\text { Age }\end{array}$ & $2 \sigma$ \\
\hline C-7-Spot-248 & 0.723 & 0.055 & 0884 & 0.0072 & 1.312220 & 0.921357 & 0623 & 0.0030 & 7987 & 547 & 32 & 544 & 43 & 680 & 110 & 0.01 & 544 & 43 \\
\hline SC-7-Spot-249 & 2.760 & 0.170 & 0.2320 & 0.0150 & 4.310345 & 0.278686 & 0.0842 & 0.0033 & 0.33521 & 1340 & 48 & 1338 & 81 & 1273 & 79 & 0.00 & 1273 & 79 \\
\hline SC-7-Spot-251 & 4.520 & 0.390 & 0.3000 & 0.0260 & 3.333333 & 0.288889 & 0.1073 & 0.0042 & 0.32596 & 1736 & 66 & 1680 & 130 & 1768 & 63 & 0.03 & 1768 & 63 \\
\hline SC-7-S & 2.290 & 0 & 9 & 0 & 9 & 4 & 0.0845 & 7 & 0 & 1192 & 52 & 40 & 67 & 13 & 83 & 04 & 1344 & 83 \\
\hline SC-7-Spot-253 & 0.865 & 0.075 & 0.1050 & 0.0110 & 9.523810 & 0.997732 & 0.0617 & 0.0028 & 0.61071 & 623 & 41 & 651 & 63 & 700 & 110 & 0.04 & 651 & 63 \\
\hline SC-7-Spot-254 & 1.970 & 0.310 & 0.1017 & 0.0098 & 9.832842 & 0.947511 & 0.1420 & 0.0170 & 0.11001 & 1090 & 110 & 622 & 58 & 2140 & 210 & 0.43 & --- & --- \\
\hline SC-7-Spot-255 & 0.853 & 0.051 & 0.1013 & 0.0055 & 9.871668 & 0.535974 & 0.0619 & 0.0025 & 0.17003 & 632 & 28 & 621 & 32 & 656 & 90 & 0.02 & 621 & 32 \\
\hline SC-7-S & 4.510 & 0.290 & 2970 & 20 & 3 & 0 & 0.1073 & 3 & 0 & 1728 & 50 & 1690 & 110 & 1760 & 56 & 02 & 1760 & 56 \\
\hline SC-7-Spot-259 & 3.380 & 0.240 & 0.2630 & 0.0200 & 3.802281 & 0.289147 & 0.0923 & 0.0036 & 0.40355 & 1498 & 57 & 1490 & 100 & 1502 & 71 & 0.01 & 1502 & 71 \\
\hline SC-7-Spot-260 & 2.120 & 0.130 & 0.2060 & 0.0180 & 4.854369 & 0.424168 & 0.0790 & 0.0033 & 0.64835 & 1146 & 42 & 1201 & 92 & 1165 & 77 & 0.05 & 1165 & 77 \\
\hline SC-7-Spot-261 & 0.878 & 0.049 & 0.1016 & 0.0058 & 9.842520 & 0.561876 & .0627 & 0.0029 & 0.4085 & 636 & 25 & 623 & 34 & 660 & 100 & 0.02 & 623 & 34 \\
\hline SC-7-Spot-262 & 0.721 & 0.040 & 0.0868 & 0.0058 & 11.520740 & 0.769819 & 0.0614 & 0.0029 & 0.51944 & 548 & 24 & 541 & 33 & 636 & 97 & 0.01 & 541 & 33 \\
\hline SC-7-S & 0.747 & 0.074 & 0.0856 & 0.0064 & 11.682240 & 0.873439 & 0.0612 & 0.0047 & 0. & 557 & 41 & 528 & 38 & 560 & 160 & 0.05 & 528 & 38 \\
\hline SC-7-Spot-264 & 0.720 & 0.060 & 0.0891 & 0.0072 & 11.223340 & 0.906937 & 0.0597 & 0.0040 & 0.38234 & 543 & 35 & 549 & 42 & 580 & 140 & 0.01 & 549 & 42 \\
\hline SC-7-Spot-265 & 0.678 & 0.061 & 0.0851 & 0.0090 & 11.750880 & 42749 & 0.0587 & 0.0032 & 0. & - & 36 & 524 & 53 & 540 & 120 & 0.01 & 524 & 53 \\
\hline SC-7-Spot-266 & 13.200 & 0.850 & 0.5250 & 0.0420 & 1.904762 & 0.152381 & 0.1821 & 0.0069 & 0.48745 & 2692 & 65 & 2690 & 180 & 2666 & 60 & 0.00 & 2666 & 60 \\
\hline t- -273 & 18 & 000 & 030 & 066 & 9.708738 & 0.622113 & 0.0589 & 0.0034 & 0.26015 & -60 & 32 & 630 & 39 & 540 & 130 & 0.04 & 630 & 39 \\
\hline SC-7-Spot-274 & 6.330 & 0.250 & 0.3620 & 0.0210 & 2.762431 & 0.160252 & 0.1270 & 0.0050 & 0.72824 & 2022 & 34 & 2000 & 100 & 2073 & 61 & 0.01 & 2073 & 61 \\
\hline SC-7-Spot-275 & 3.180 & .270 & 200 & 0.0100 & 8.333333 & 0.694444 & 0.1950 & 0.0120 & 0.47921 & 1435 & 61 & 729 & 58 & 2753 & 96 & 0.49 & --- & -- \\
\hline SC-7-Spot-276 & 1.184 & 0.080 & 0.0974 & 0.0060 & 10.266940 & 0.632460 & 0.0882 & 0.0047 & 0.32959 & 786 & 37 & 598 & 35 & 1365 & 97 & 0.24 & --- & --- \\
\hline SC-7-Spot-277 & 0.859 & 0.038 & 0.000 & 0.0066 & 9.624639 & 0.611382 & 0.0603 & 0.0023 & 0.74248 & 107 & 21 & 636 & 39 & 605 & 79 & 0.01 & 636 & 39 \\
\hline SC-7-Spot-278 & 6.430 & 0.560 & 0.3250 & 0.0200 & 3.076923 & 0.189349 & 0.1403 & 0.0082 & 0.16075 & 2022 & 73 & 1840 & 98 & 2194 & 94 & 0.09 & 2194 & 94 \\
\hline SC-7-Spot-297 & 1.097 & 0.045 & 1267 & 0.0080 & 7.892660 & 0.498353 & 0.0631 & 0.0030 & 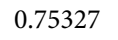 & 749 & 22 & 767 & 46 & 696 & 94 & 0.02 & 767 & 46 \\
\hline SC-7-Spot-298 & 0.768 & 0.061 & 0.0879 & 0.0064 & 11.376560 & 0.828328 & 0.0601 & 0.0040 & 0.44436 & 584 & 35 & 542 & 38 & 570 & 140 & 0.07 & 542 & 38 \\
\hline SC-7-Spot-299 & 0.741 & 0.071 & 0.0842 & 0.0084 & 11.876480 & 1.184827 & 0.0620 & 0.0041 & 0.26852 & 563 & 40 & 519 & 50 & 670 & 140 & 0.08 & 519 & 50 \\
\hline SC-7-Spot-300 & 1.055 & 0.054 & 00957 & 0.0059 & 10.449320 & 0.644211 & 0.0803 & 0.0033 & 0.22923 & 734 & 28 & 589 & 35 & 1212 & 85 & 0.20 & --- & -- \\
\hline SC-7-Spot-301 & 2.320 & 0.180 & 0.1970 & 0.0120 & 5.076142 & 0.309207 & 0.0852 & 0.0053 & 0.06324 & 1204 & 55 & 1158 & 66 & 1300 & 110 & 0.04 & 1300 & 110 \\
\hline SC-7-Spot-302 & 2.980 & 0.230 & 0.2410 & 0.0220 & 4.149378 & 0.378781 & 0.0903 & 0.0048 & 0.53813 & 1397 & 60 & 1380 & 110 & 1400 & 100 & 0.01 & 1400 & 100 \\
\hline SC-7-Spot-303 & 0.943 & 0.073 & 0.1019 & 0.0075 & 9.813543 & 0.722292 & 0.0647 & 0.0039 & 0.50202 & 674 & 37 & 624 & 44 & 720 & 120 & 0.07 & 624 & 44 \\
\hline SC-7-Spot-304 & 0.613 & 0.040 & 0.0805 & 0.0064 & 12.422360 & 0.987616 & 0.0563 & 0.0021 & 0.56786 & 107 & 25 & 498 & 38 & 457 & 81 & 0.03 & 498 & 38 \\
\hline SC-7-Spot-305 & 0.714 & 0.068 & 0.0871 & 0.0065 & 11.481060 & 0.856795 & 0.0579 & 0.0050 & 0.29327 & 538 & 40 & 537 & 38 & 430 & 180 & 0.00 & 537 & 38 \\
\hline SC-7-Spot-306 & 0.875 & 0.054 & 0.1010 & 0.0071 & 9.900990 & 0.696010 & 0.0636 & 0.0026 & 0.43358 & 635 & 29 & 619 & 42 & 722 & 84 & 0.03 & 619 & 42 \\
\hline
\end{tabular}


Appendix B. Continued.

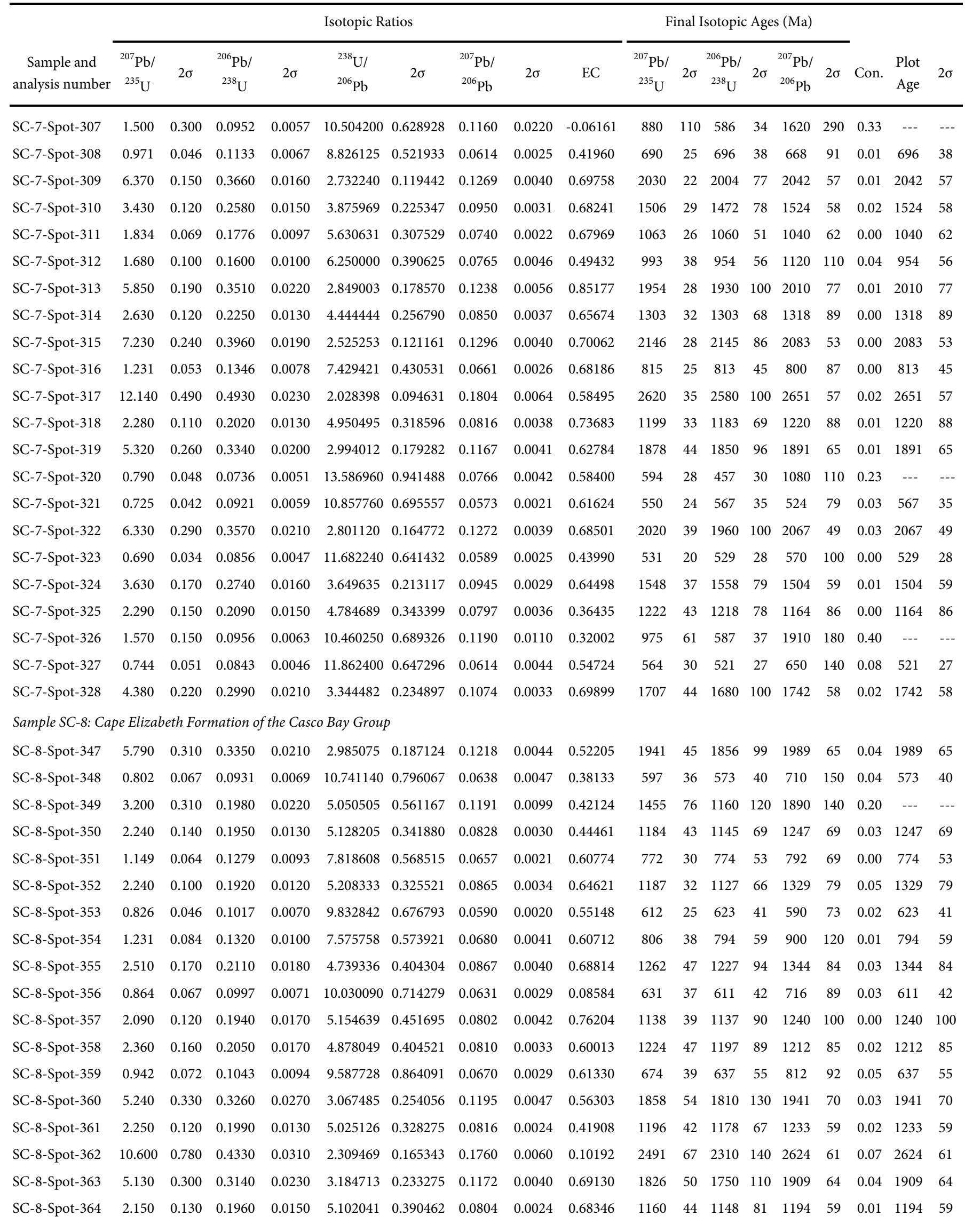


Appendix B. Continued.

\begin{tabular}{|c|c|c|c|c|c|c|c|c|c|c|c|c|c|c|c|c|c|c|}
\hline $\begin{array}{c}\text { Sample and } \\
\text { analysis number }\end{array}$ & \multicolumn{9}{|c|}{ Isotopic Ratios } & \multicolumn{6}{|c|}{ Final Isotopic Ages (Ma) } & Con. & $\begin{array}{l}\text { Plot } \\
\text { Age }\end{array}$ & $2 \sigma$ \\
\hline-365 & 1.610 & 0.130 & 1640 & 0.0100 & 6.097561 & 0.371803 & 0722 & 0.0049 & 1722 & 961 & 50 & 976 & 55 & 950 & 130 & 0.02 & 976 & 55 \\
\hline SC-8-Spot-366 & 1.730 & 0.180 & 0.1650 & 0.0150 & 6.060606 & 0.550964 & 0.0776 & 0.0055 & 0.21117 & 1017 & 63 & 996 & 80 & 1100 & 140 & 0.02 & 996 & 80 \\
\hline SC-8-Spot-368 & 4.340 & 0.430 & 0.3050 & 0.0360 & 3.278689 & 0.386993 & 0.1034 & 0.0054 & 0.31309 & 1702 & 94 & 1730 & 190 & 1698 & 91 & 0.02 & 1698 & 91 \\
\hline SC-8-Spot-369 & 1.090 & 0.110 & 0.1210 & 0.0120 & 8.264463 & 0.819616 & (1) & 0.0037 & ש. & 102 & 52 & 735 & 68 & 690 & 120 & 0.00 & 735 & 68 \\
\hline SC-8-Spot- 370 & 0.880 & 0.100 & 0.1020 & 0.0120 & 9.803922 & 1.153403 & 0.0606 & 0.0046 & 0.26856 & 623 & 55 & 622 & 68 & 570 & 170 & 0.00 & 622 & 68 \\
\hline SC-8-Spot-371 & 0.789 & 0.069 & 0.0835 & 0.0062 & 11.976050 & 0.889240 & 0.0664 & 0.0038 & 0.34332 & 589 & 39 & 523 & 39 & 810 & 120 & 0.11 & 523 & 39 \\
\hline SC-8-Spot-372 & 1.674 & 0.097 & 0.1680 & 0.0120 & 5.952381 & 0.425170 & 0.0730 & 0.0037 & 0.63014 & 998 & 38 & 995 & 68 & 1029 & 99 & 0.00 & 995 & 68 \\
\hline SC-8-Spot-376 & 0.765 & 0.051 & 0.0918 & 0.0064 & 10.893250 & 0.759442 & 0.0608 & 0.0020 & 0.33025 & (3) & 30 & 305 & 38 & 628 & 72 & 0.02 & 565 & 38 \\
\hline SC-8-Spot-377 & 0.908 & 0.072 & 0.1051 & 0.0080 & 9.514748 & 0.724243 & 0.0644 & 0.0028 & 48 & 657 & 40 & 642 & 47 & 753 & 95 & 0.02 & 642 & 47 \\
\hline SC-8-Spot-378 & 0.956 & 0.061 & 0.1115 & 0.0069 & 8.968610 & 0.555008 & 0.0650 & 0.0032 & 0.51788 & 681 & 31 & 680 & 40 & 750 & 100 & 0.00 & 680 & 40 \\
\hline SC-8-Spot-397 & 5.890 & 0.490 & 0.3520 & 0.0380 & 2.840909 & 0.306689 & 215 & 0.0074 & 0.57451 & 1945 & 74 & 1980 & 180 & 1980 & 110 & 0.02 & 1980 & 110 \\
\hline SC-8-Spot-398 & 0.880 & 0.085 & 0.1100 & 0.0130 & 9.090909 & 1.074380 & 0.0597 & 0.0024 & 0.56786 & 637 & 47 & 665 & 75 & 602 & 98 & 0.04 & 665 & 75 \\
\hline SC-8-Spot-399 & 0.830 & 0.095 & 0.1100 & 0.0130 & 9.090909 & 1.074380 & $58-2-1$ & 0.0051 & S & 607 & 55 & 668 & 74 & 500 & 170 & 0.10 & 668 & 74 \\
\hline SC-8-Spot-400 & 0.817 & 0.090 & 0.1000 & 0.0110 & 10.000000 & 1.100000 & 0.0602 & 0.0035 & 0.44845 & 593 & 50 & 608 & 62 & 610 & 120 & 0.03 & 608 & 62 \\
\hline SC-8-Spot-401 & 2.180 & 0.180 & 0.2090 & 0.0210 & 4.784689 & 0.480758 & 0789 & 0.0042 & 0. & 1167 & 57 & 1210 & 110 & 1160 & 110 & 0.04 & 1160 & 110 \\
\hline SC-8-Spot-402 & 1.650 & 0.140 & 0.1420 & 0.0130 & 7.042254 & 0.644713 & 0.0826 & 0.0044 & 0.47499 & 989 & 58 & 851 & 75 & 1260 & 100 & 0.14 & 851 & 75 \\
\hline $8-5$ pol-409 & 1.066 & (5) & 230 & 150 & 130081 & 0.991473 & 643 & 0.0041 & 0.65399 & 722 & 46 & 740 & 87 & 680 & 140 & 0.02 & 740 & 87 \\
\hline SC-8-Spot-410 & 1.750 & 0.100 & 0.1620 & 0.0100 & 6.172840 & 0.381040 & 0.0788 & 0.0048 & 0.46907 & 1020 & 37 & 967 & 58 & 1160 & 110 & 0.05 & 967 & 58 \\
\hline SC-8-Spot-411 & 0.906 & .073 & 0.1032 & 069 & 9.689922 & 0.647873 & 0.0607 & 0.0034 & 0.36278 & 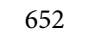 & 38 & 631 & 40 & 600 & 120 & 0.03 & 631 & 40 \\
\hline SC-8-Spot-412 & 5.100 & 0.340 & 0.3220 & 0.0250 & 3.105590 & 0.241117 & 0.1156 & 0.0046 & 0.48444 & 1827 & 56 & 1780 & 120 & 1893 & 76 & 0.03 & 1893 & 76 \\
\hline SC-8-Spot-413 & 0.944 & 0.093 & 30 & 20 & 8.849558 & 9776 & 4 & 36 & 0.41720 & 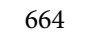 & 48 & 50 & 67 & 630 & 130 & 0.03 & 685 & 67 \\
\hline SC-8-Spot-414 & 0.709 & 0.061 & 0.0871 & 0.0086 & 11.481060 & 1.133606 & 0.0585 & 0.0032 & 0.44574 & 531 & 33 & 536 & 50 & 550 & 120 & 0.01 & 536 & 50 \\
\hline SC-8-Spot-415 & 2.080 & 0.140 & 950 & 80 & 5.128205 & 0.473373 & 0.0788 & 0.0034 & 0.41145 & 1131 & 45 & 1139 & 95 & 1152 & 87 & 0.01 & 1152 & 87 \\
\hline SC-8-Spot-416 & 6.250 & 0.810 & 0.3560 & 0.0480 & 2.808989 & 0.378740 & 0.1243 & 0.0076 & 0.43437 & 1950 & 110 & 1960 & 230 & 2040 & 100 & 0.01 & 2040 & 100 \\
\hline SC-8-Spot-417 & 2.250 & 0.200 & 0.2030 & 0.0170 & 4.926108 & 0.412531 & 0.0811 & 0.0042 & 0.20557 & 1205 & 64 & 1185 & 92 & 1246 & 85 & 0.02 & 1246 & 85 \\
\hline SC-8-Spot-418 & 0.906 & 0.070 & 01045 & 0.0096 & 9.569378 & 0.879101 & 0.0644 & 0.0031 & 0.48632 & 648 & 36 & 638 & 55 & 750 & 100 & 0.02 & 638 & 55 \\
\hline SC-8-Spot-419 & 0.834 & 0.069 & 0.0931 & 0.0086 & 10.741140 & 0.992200 & 0.0655 & 0.0038 & 0.39888 & 607 & 38 & 572 & 50 & 780 & 120 & 0.06 & 572 & 50 \\
\hline SC-8-Spot-420 & 5.920 & 0.460 & 0.3360 & 0.0310 & 2.976190 & 0.274589 & 0.1311 & 0.0055 & 0.58079 & 1953 & 63 & 1850 & 150 & 2093 & 73 & 0.05 & 2093 & 73 \\
\hline SC-8-Spot-421 & 0.841 & 0.042 & 0.0938 & 0.0054 & 10.660980 & 0.613745 & 0.0643 & 0.0033 & 0.59599 & 617 & 23 & 577 & 32 & 750 & 110 & 0.06 & 577 & 32 \\
\hline SC-8-Spot-422 & 0.690 & 0.140 & 0.0823 & 0.0057 & 12.150670 & 0.841541 & 0.0546 & 0.0035 & -0.16153 & 105 & 30 & 509 & 34 & 340 & 140 & 0.05 & 509 & 34 \\
\hline SC-8-Spot-423 & 4.950 & 0.190 & 0.3110 & 0.0190 & 3.215434 & 0.196441 & 0.1180 & 0.0040 & 0.72369 & 1822 & 31 & 1739 & 91 & 1910 & 63 & 0.05 & 1910 & 63 \\
\hline SC-8-Spot- 424 & 0.771 & 0.042 & 0.0920 & 0.0052 & 10.869570 & 0.614367 & 0.0613 & 0.0030 & 0.43197 & 577 & 24 & 572 & 29 & 610 & 110 & 0.01 & 572 & 29 \\
\hline
\end{tabular}


Appendix B. Continued.

\begin{tabular}{|c|c|c|c|c|c|c|c|c|c|c|c|c|c|c|c|c|c|c|}
\hline $\begin{array}{c}\text { Sample and } \\
\text { analysis number }\end{array}$ & \multicolumn{9}{|c|}{ Isotopic Ratios } & \multicolumn{6}{|c|}{ Final Isotopic Ages (Ma) } & Con. & $\begin{array}{l}\text { Plot } \\
\text { Age }\end{array}$ & $2 \sigma$ \\
\hline SC-8-S & 2.010 & 110 & 1880 & 0.0100 & 319149 & 0.282934 & 0773 & 0.0036 & 7932 & 1115 & 40 & 1109 & 57 & 1126 & 98 & 0.01 & 1126 & 98 \\
\hline SC-8-Spot- 426 & 0.786 & 0.056 & 0.0840 & 0.0047 & 11.904760 & 0.666100 & 0.0692 & 0.0042 & 0.32664 & 594 & 29 & 524 & 27 & 860 & 130 & 0.12 & 524 & 27 \\
\hline SC-8-Spot- 428 & 0.909 & 0.059 & 0.1062 & 0.0083 & 9.416196 & 0.735917 & 0.0625 & 0.0032 & 0.55276 & 651 & 31 & 649 & 48 & 700 & 100 & 0.00 & 649 & 48 \\
\hline$S C-8-S_{1}$ & 3.430 & 0 & 2550 & 0 & 9 & 7 & 7 & 0 & 0.32707 & 3 & 48 & 54 & 90 & 96 & 6 & 04 & 1596 & 66 \\
\hline SC-8-Spot- 449 & 1.990 & 0.180 & 0.1770 & 0.0120 & 5.649718 & 0.383032 & 0.0845 & 0.0063 & 0.15200 & 1078 & 40 & 1044 & 66 & 1270 & 120 & 0.03 & 1270 & 120 \\
\hline SC-8-Spot-450 & 2.680 & 0.230 & 0.1740 & 0.0230 & 5.747126 & 0.759678 & 0.1180 & 0.0098 & 0.72656 & 1350 & 69 & 1030 & 120 & 1870 & 150 & 0.24 & --- & --- \\
\hline SC-8-Spot- 451 & 1.700 & 0.140 & 0.1620 & 0.0140 & 6.172840 & 0.533455 & 0.0740 & 0.0031 & 0.30109 & 1002 & 52 & 976 & 77 & 1033 & 80 & 0.03 & 976 & 77 \\
\hline SC-8-Spot-454 & 0.882 & 0.062 & 0.0962 & 0.0076 & 10.395010 & 0.821227 & 0.0678 & 0.0037 & 0.50970 & 050 & 33 & 370 & 45 & 830 & 110 & 0.07 & 590 & 45 \\
\hline SC-8-Spot-455 & 0.798 & 0.057 & 0.0894 & 0.0049 & 11.185680 & 0.613086 & 0.0663 & 0.0043 & 0.07203 & 590 & 31 & 551 & 29 & 760 & 120 & 0.07 & 551 & 29 \\
\hline SC-8-Spot-456 & 0.848 & 0.032 & 0.0983 & 0.0052 & 10.172940 & 0.538141 & 0.0647 & 0.0022 & 0.68051 & 622 & 18 & 604 & 30 & 747 & 72 & 0.03 & 604 & 30 \\
\hline $\mathrm{SC}-8-\mathrm{Sp}_{\mathrm{F}}$ & 5.520 & 0.360 & 0.3100 & 0.0230 & 3.225806 & 0.239334 & 320 & 0.0051 & 04 & 1896 & 56 & 1730 & 110 & 2106 & 68 & 0.09 & 2106 & 68 \\
\hline SC-8-Spot-458 & 4.390 & 0.210 & 0.2830 & 0.0220 & 3.5 & 0.274694 & 0.1133 & 0.0055 & 0.71755 & 1702 & 39 & 1590 & 110 & 1880 & 86 & 0.07 & 1880 & 86 \\
\hline SC-8-S & 2.040 & 110 & 0.1890 & 0.0130 & 5.291005 & 3932 & 0.0794 & 0.0029 & 0.6 & 1128 & 35 & 1109 & 71 & 1198 & 76 & 0.02 & 1198 & 76 \\
\hline SC-8-Spot-460 & 2.420 & 0.140 & 0.2120 & 0.0170 & 4.716981 & 0.378249 & 0.0834 & 0.0047 & 0.78285 & 1238 & 40 & 1270 & 100 & 1270 & 100 & 0.03 & 1270 & 100 \\
\hline SC-8-Spot-461 & 1.330 & 130 & 1400 & 0.0110 & 7.142857 & 0.561225 & 0.0699 & 0.0068 & 022 & $T J$ & 53 & 40 & 63 & 10 & 200 & 0.00 & 840 & 63 \\
\hline SC-8-Spot-462 & 2.110 & 0.140 & 0.1890 & 0.0160 & 5.291005 & 0.447916 & 0.0799 & 0.0040 & 0.48820 & 1149 & 47 & 1107 & 86 & 1180 & 100 & 0.04 & 1180 & 100 \\
\hline SC-8-S & 1.580 & ( & 640 & 0.0110 & .097561 & 08983 & 0719 & 031 & - 1004 & 00 & 34 & (374 & 61 & 100 & 84 & 0.02 & 74 & 61 \\
\hline SC-8-Spot-470 & 4.850 & 0.270 & 0.3140 & 0.0210 & 3.184713 & 0.212990 & 0.1144 & 0.0041 & 0.60015 & 1813 & 46 & 1750 & 100 & 1867 & 61 & 0.03 & 1867 & 61 \\
\hline SC-8-Spot-471 & 4.760 & 220 & 80 & 0.0200 & 246753 & 210828 & 126 & 044 & 000 & 1772 & 38 & 1720 & 100 & 1826 & 70 & 0.03 & 1826 & 70 \\
\hline SC-8-Spot-472 & 0.830 & 0.044 & 0.0987 & 0.0065 & 10.131710 & 0.667235 & 0.0616 & 0.0027 & 0.66137 & 610 & 25 & 611 & 37 & 663 & 96 & 0.00 & 611 & 37 \\
\hline SC-8-Spot-473 & 0.675 & 0.041 & 02 & 53 & 3830 & 4000 & 16 & 35 & w & 530 & 25 & 497 & 31 & 30 & 130 & 0.06 & 497 & 31 \\
\hline SC-8-Spot-474 & 0.719 & 0.057 & 0.0904 & 0.0070 & 11.061950 & 0.856567 & 0.0581 & 0.0041 & 0.15859 & 543 & 33 & 556 & 41 & 460 & 150 & 0.02 & 556 & 41 \\
\hline SC-8-Spot-475 & 0.652 & 1 & 827 & 75 & 12 & 1.096605 & 568 & 032 & 102 & 509 & 30 & 510 & 44 & 460 & 120 & 0.00 & 510 & 44 \\
\hline SC-8-Spot-476 & 0.869 & 0.062 & 0.0988 & 0.0090 & 10.121460 & 0.921995 & 0.0619 & 0.0033 & 0.67890 & 641 & 36 & 605 & 52 & 680 & 110 & 0.06 & 605 & 52 \\
\hline SC-8-Spot-477 & 0.990 & 0.100 & 0.0989 & 0.0088 & 10.111220 & 0.899684 & 0.0718 & 0.0068 & 5726 & 690 & 49 & 606 & 52 & 880 & 180 & 0.12 & 606 & 52 \\
\hline SC-8-Spot-478 & 2.140 & 0.100 & 01950 & 0.0120 & 5.128205 & 0.315582 & 0.0796 & 0.0031 & 0.52813 & 1158 & 32 & 1145 & 66 & 1203 & 73 & 0.01 & 1203 & 73 \\
\hline SC-8-Spot-479 & 1.098 & 0.061 & 0.1277 & 0.0094 & 7.830854 & 0.576429 & 0.0638 & 0.0026 & 0.69864 & 748 & 29 & 772 & 54 & 724 & 82 & 0.03 & 772 & 54 \\
\hline SC-8-Spot-498 & 2.870 & 0.180 & 0.2400 & 0.0300 & 4.166667 & 0.520833 & 0.0908 & 0.0083 & 0.90849 & 1376 & 49 & 1370 & 150 & 1460 & 170 & 0.00 & 1460 & 170 \\
\hline SC-8-Spot-499 & 11.780 & 0.620 & 0.4770 & 0.0380 & 2.096436 & 0.167012 & 0.1767 & 0.0086 & 0.80318 & 2597 & 52 & 2490 & 160 & 2615 & 75 & 0.04 & 2615 & 75 \\
\hline SC-8-Spot-500 & 0.842 & 0.048 & 0.1019 & 0.0062 & 9.813543 & 0.597095 & 0.0592 & 0.0031 & 0.65894 & 620 & 26 & 625 & 36 & 550 & 110 & 0.01 & 625 & 36 \\
\hline SC-8-Spot-501 & 5.670 & 0.310 & 0.3490 & 0.0230 & 2.865330 & 0.188833 & 0.1232 & 0.0066 & 0.68131 & 1934 & 50 & 1920 & 110 & 2020 & 96 & 0.01 & 2020 & 96 \\
\hline SC-8-Spot-502 & 4.910 & 0.300 & 0.3160 & 0.0200 & 3.164557 & 0.200288 & 0.1160 & 0.0054 & 0.55132 & 1807 & 51 & 1764 & 97 & 1868 & 85 & 0.02 & 1868 & 85 \\
\hline
\end{tabular}


Appendix B. Continued.

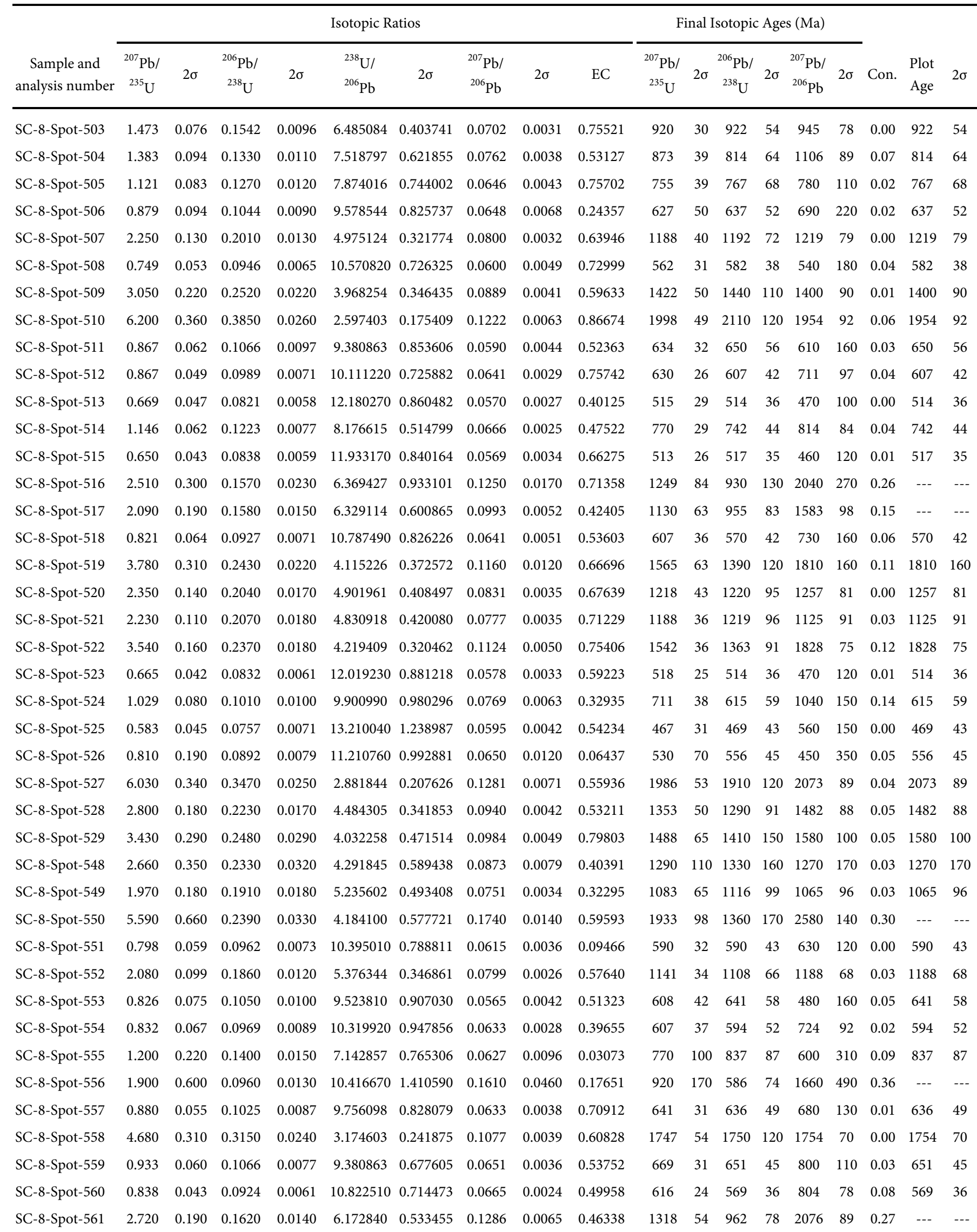


Isotopic Ratios

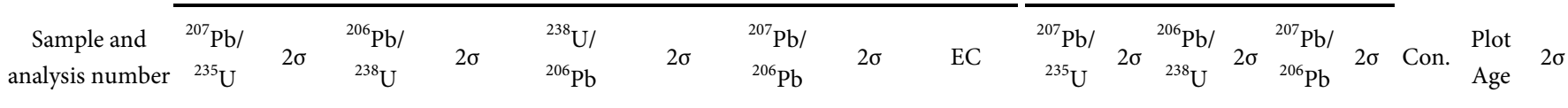

\begin{tabular}{|c|c|c|c|c|c|c|c|c|c|c|c|c|c|c|c|c|c|c|}
\hline 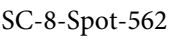 & & & & & & & & & & & 48 & & 1 & & 70 & 9 & 8 & 70 \\
\hline 3 & or & & & & & & & & & & & & & & 0 & & 5 & \\
\hline & & & & & & & & & & & & & & & 0 & & & \\
\hline & 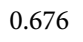 & & & & 7910 & & & & & & 58 & & & & 60 & & 530 & \\
\hline & 1.007 & & & & & & & & & & 45 & & & & 0 & & & 47 \\
\hline 年 & 00 & & & & & & & & & & 25 & & 12 & & 0 & & & 42 \\
\hline & & & & & & & & & & & 47 & & & & 0 & & & \\
\hline & & & & & & & & & & & 0 & & & & 10 & & & 39 \\
\hline & .080 & & & & & & & & & & 8 & & & 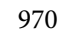 & 0 & & 7 & \\
\hline & .240 & & & & & & & & & & 41 & & & & 78 & & & 78 \\
\hline & & & & & & & & & & & 9 & & & & 0 & & 2 & 63 \\
\hline & 4.800 & & & & & & & & & & 6 & & & & & & & 12 \\
\hline SC-8-Spot-574 & .340 & & & & & & & & & & 6 & & & 19 & 81 & & 1 & 81 \\
\hline & 682 & & & & & & & & & & 33 & & & 570 & 0 & & 0 & 32 \\
\hline & 64 & & & & & & & & & & 52 & & 0 & 21 & 66 & 4 & & 66 \\
\hline & & & & & & & & & & & & & & U & 0 & & 834 & 63 \\
\hline & & & & & & & & & & & & & & & 0 & & & 55 \\
\hline & & & & & & & & & & & 29 & & 9 & & 4 & & & 4 \\
\hline & & & & & & & & & & & 7 & & & & 0 & & & 60 \\
\hline 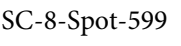 & 00 & & & & & & & & & & & & & 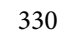 & 280 & & & 60 \\
\hline & & & & & & & & & & & 38 & & & & 8 & & & 58 \\
\hline & 822 & & & & & & & & & & & & & 580 & 0 & & & 0 \\
\hline & & & & & & & & & & & 0 & & & 0 & 0 & 5 & 0 & 13 \\
\hline & & & & & & & & & & & 4 & & 0 & & 0 & & & 0 \\
\hline 04 & 070 & 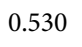 & & & & & & & & & 30 & & 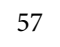 & U & 560 & & 630 & 57 \\
\hline & & & & & & & & & & & 10 & & & & 60 & 20 & & \\
\hline 06 & $7 / 3$ & \pm & & & & & & & & & 19 & & & 6 & 66 & & 581 & 29 \\
\hline SC-8-Spot-607 & 54 & 0.400 & & & 2.403846 & & & & & & 39 & & 5 & 25 & 45 & 5 & 7 & 45 \\
\hline & 170 & & & & & & & & & & & & 32 & 14 & 50 & .24 & 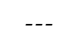 & \\
\hline (v) & 500 & 0.280 & & & & & & & & & 32 & & U & 18 & 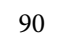 & & 6 & 90 \\
\hline SC-8-Spot- 610 & 82 & & & 2 & & & & & & & 9 & & 7 & & 200 & 0.21 & --- & \\
\hline $\mathrm{C}-$ & $0 / 0$ & 10 & & 0 & & & & & & 990 & 6 & 948 & 81 & 90 & 170 & 4 & 948 & 1 \\
\hline . & 500 & 0.580 & & 0 & 90 & 9 & 34 & 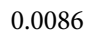 & & 005 & OJ & 10 & 150 & 19 & 130 & 00 & 1950 & \\
\hline C-8-Spot-612 & 982 & 097 & .0998 & 0068 & 10.020040 & 0.682728 & 704 & 0068 & .28085 & 681 & 48 & 612 & 40 & 850 & 180 & 0.10 & 612 & \\
\hline
\end{tabular}

Sample SC-9: Vassalboro Group of the Central Maine sequence

$\begin{array}{llllllllll}\text { SC-9-Spot-10 } & 1.870 & 0.120 & 0.1900 & 0.0170 & 5.263158 & 0.581718 & 0.0739 & 0.0032 & 0.70696 \\ \text { SC-9-Spot-11 } & 2.820 & 0.110 & 0.2410 & 0.0130 & 4.149378 & 0.223825 & 0.0849 & 0.0028 & 0.79583 \\ \text { SC-9-Spot-12 } & 2.149 & 0.089 & 0.2030 & 0.0140 & 4.926108 & 0.339732 & 0.0805 & 0.0028 & 0.73269 \\ \text { SC-9-Spot-13 } & 1.886 & 0.080 & 0.1868 & 0.0099 & 5.353319 & 0.283714 & 0.0746 & 0.0024 & 0.74501 \\ \text { SC-9-Spot-14 } & 1.656 & 0.066 & 0.1680 & 0.0100 & 5.952381 & 0.354308 & 0.0734 & 0.0036 & 0.73617 \\ \text { SC-9-Spot-15 } & 3.640 & 0.140 & 0.2750 & 0.0150 & 3.636364 & 0.198347 & 0.0971 & 0.0031 & 0.55902\end{array}$

$\begin{array}{lllllllll}1083 & 43 & 1136 & 85 & 1022 & 90 & 0.05 & 1022 & 90\end{array}$

$\begin{array}{lllllllll}1371 & 27 & 1389 & 70 & 1307 & 65 & 0.01 & 1307 & 65\end{array}$

$\begin{array}{lllllllll}1165 & 30 & 1197 & 71 & 1190 & 70 & 0.03 & 1190 & 70\end{array}$

$\begin{array}{lllllllll}1076 & 27 & 1101 & 53 & 1063 & 61 & 0.02 & 1063 & 61\end{array}$

$\begin{array}{lllllllll}993 & 24 & 1001 & 57 & 1000 & 110 & 0.01 & 1000 & 110\end{array}$

$\begin{array}{lllllllll}1553 & 32 & 1563 & 77 & 1555 & 60 & 0.01 & 1555 & 60\end{array}$ 
Appendix B. Continued.

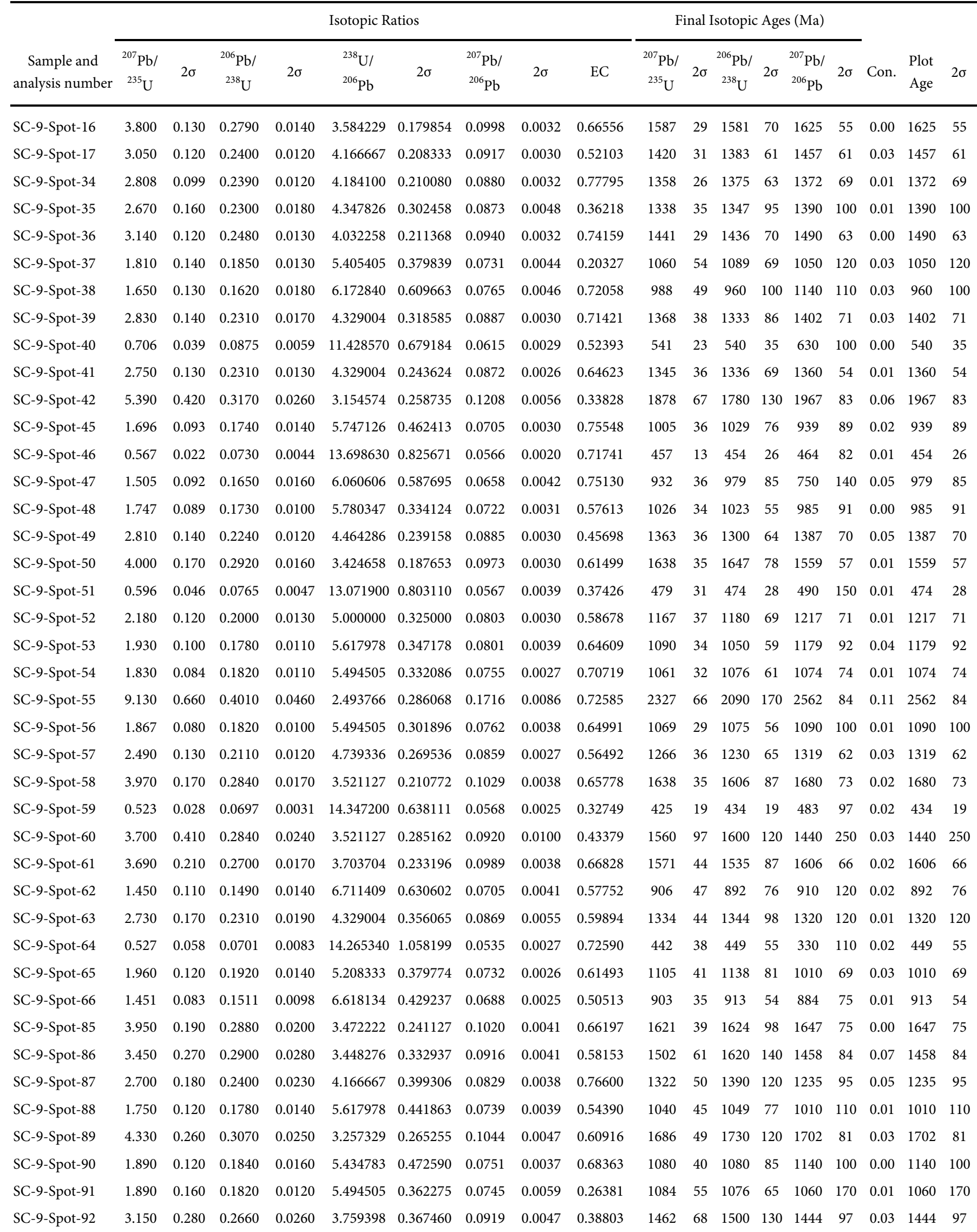


Isotopic Ratios

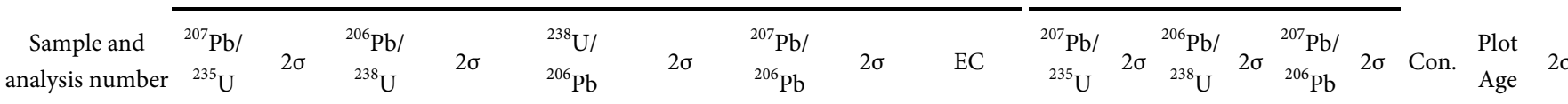

\begin{tabular}{|c|c|c|c|c|c|c|c|c|c|c|c|c|c|c|c|c|c|c|}
\hline C-9 & 637 & 099 & 630 & 0120 & 969 & 654 & 0727 & 0031 & 64728 & 76 & 37 & 970 & 64 & 003 & 35 & 01 & 970 & 54 \\
\hline 4 & 502 & 034 & 667 & 0058 & 500 & 696 & 1 & 023 & & 418 & 23 & 420 & 34 & 492 & 89 & .00 & 420 & 34 \\
\hline 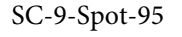 & 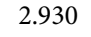 & & & & & & & & & 402 & 65 & 380 & 130 & 1480 & 100 & .02 & 1480 & 100 \\
\hline 96 & 609 & 44 & 808 & 075 & 6240 & 1.148784 & 0566 & 035 & 7907 & 479 & 8 & 499 & 45 & 470 & 140 & .04 & 499 & 45 \\
\hline 7 & 630 & 0.470 & 430 & 30 & 452 & 0 & 5 & 8 & & 906 & 8 & 1910 & 160 & 893 & 76 & .00 & 1893 & 6 \\
\hline ( & 380 & 0.160 & & & & 914 & 0710 & 045 & & 066 & 59 & 1114 & 89 & 1010 & 130 & .04 & 1010 & 130 \\
\hline C_o_snet & 070 & 320 & 010 & 70 & & 10 & 0994 & 041 & & 674 & 64 & 1680 & 130 & 619 & 69 & .00 & 1619 & 69 \\
\hline C-9. & 1.730 & 0.120 & & 0.0160 & & & 38 & 0.0033 & & 1038 & 48 & 1048 & 89 & 1028 & 93 & 0.01 & 1028 & 93 \\
\hline C-9- & 2.280 & 200 & & 30 & 5 & 207 & 55 & 36 & & 205 & 61 & 1270 & 120 & 060 & 100 & 0.05 & 1060 & 100 \\
\hline 02 & 4.090 & 0.270 & & 260 & & 0 & 9 & & & 3 & 52 & 1660 & 130 & 37 & 93 & .00 & 637 & 3 \\
\hline 03 & 970 & 0 & & 90 & & & 3 & & & 397 & 42 & 1388 & 97 & 1342 & 91 & 0.01 & 1342 & 91 \\
\hline C-9-Spo & 3.740 & .220 & 40 & 90 & & & & 10 & & 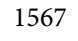 & 47 & 1618 & 94 & 436 & 9 & .03 & 1436 & 79 \\
\hline C-9-Spot-105 & 4.150 & 0.240 & 880 & 0.0160 & & & 0.1028 & & & 1667 & 48 & 1624 & 82 & 1680 & 110 & 0.03 & 1680 & 110 \\
\hline 06 & 900 & 170 & & & & & 72 & & & 1612 & 34 & 1598 & 85 & 51 & 69 & 0.01 & 1551 & 99 \\
\hline C-9- & 4.920 & 0 & & & & & & & & 805 & 36 & 1860 & 110 & 727 & 76 & 0.03 & 1727 & 76 \\
\hline C-9-Spot-108 & 4.290 & 0.210 & & 0.0200 & & & & & & 1682 & 39 & 1632 & 98 & 1720 & 100 & 0.03 & 1720 & 100 \\
\hline 09 & 1.766 & 0.061 & & 081 & 531 & & 707 & 029 & & 1031 & 22 & 1053 & 44 & 925 & 87 & 0.02 & נישל & 87 \\
\hline C-9-Spot-110 & 0.559 & 0.034 & 0726 & 0.0067 & 13.774100 & 1.271164 & 0.0550 & 0.0043 & & 452 & 21 & 450 & 40 & 400 & 170 & 0.00 & 450 & 40 \\
\hline -9-spot-111 & 4.140 & .700 & & 400 & & & & 80 & & 2753 & 47 & 2740 & 170 & 2700 & 61 & 0.00 & 2700 & 61 \\
\hline C-9-Spot-112 & 982 & 0.095 & & ( & 5.4 & 03 & & 8 & & 1115 & 30 & 1116 & 52 & 1051 & 79 & 0.00 & 1051 & 79 \\
\hline 113 & 5.520 & 0.200 & 360 & 50 & 190 & 866 & 136 & 35 & & 1898 & 32 & 1861 & 74 & 1844 & 56 & 0.02 & 1844 & 56 \\
\hline C-9-Spot & 1.000 & 0 & & & & & & & & 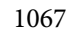 & 2 & \pm & 90 & 0 & 0 & 04 & 1050 & 160 \\
\hline C-9-Spot-115 & .050 & 170 & 1930 & 0.0170 & 5.181347 & 0.429542 & 0.0763 & 0.0056 & .11010 & 28 & 0 & 32 & 91 & 1080 & 150 & 0.00 & 1080 & 150 \\
\hline 16 & 4.580 & 0.360 & 70 & 10 & & & 45 & 54 & & 1721 & 65 & 1710 & 150 & 1683 & 95 & 0.01 & 1683 & 95 \\
\hline $\mathrm{C}-\mathrm{S}$ & 690 & 0.430 & & 70 & 3 & 00 & 0 & 7 & & 2178 & 31 & 1970 & 160 & 2458 & 8 & 0.12 & 2458 & 34 \\
\hline 36 & 4.020 & 210 & 970 & 20 & 03 & 408 & 987 & 42 & 27 & 1641 & 43 & 1680 & 100 & 1586 & 82 & 0.02 & 1586 & 32 \\
\hline C & 0 & 33 & & & & & & & & 498 & 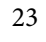 & 504 & 46 & 420 & 140 & 0.01 & 504 & 46 \\
\hline C-9-Spot-138 & 3.470 & 0.180 & 0.2660 & 0.0190 & & & 0.0961 & & & 1524 & 41 & 1512 & 97 & 1522 & . & 0.01 & 1522 & 87 \\
\hline C-9-Spot & 3.020 & 0.190 & & & & & & & & 1415 & 49 & 1412 & 88 & 1445 & 70 & 0.00 & 1445 & 70 \\
\hline C-9-Spot & 4.210 & 0.240 & 020 & 200 & 58 & 89 & 10 & 046 & 24 & 1664 & 47 & 1691 & 97 & 1629 & 81 & 0.02 & 1629 & 81 \\
\hline 43 & 4.130 & 0.230 & 90 & 10 & 208 & 34 & 52 & 42 & 990 & 654 & 47 & 1620 & 110 & 1719 & 71 & 0.02 & 1719 & 71 \\
\hline 44 & 1.960 & 40 & 20 & 10 & 505 & 86 & 75 & 046 & 41 & 1104 & 51 & 1083 & 65 & 1120 & 130 & 0.02 & 1120 & 130 \\
\hline 45 & 00 & 00 & 80 & 40 & 78 & 63 & 60 & 40 & & 1057 & 38 & 3 & 73 & 1070 & 110 & 0.00 & 1070 & 110 \\
\hline 46 & 1.963 & 0.096 & & 098 & & 06 & & & & 102 & 34 & 1070 & 53 & 140 & 100 & 0.03 & 1140 & 100 \\
\hline SC-9 & 900 & 0.130 & 310 & 0.0180 & 004 & & 0.0 & 42 & & 1388 & 30 & 1332 & 94 & 1458 & 90 & 0.04 & 1458 & 90 \\
\hline 49 & 7.100 & 300 & 00 & 50 & 567 & 67 & 88 & 092 & 70 & 31 & 73 & 3000 & 220 & 2800 & 76 & 0.02 & 2800 & 76 \\
\hline 50 & 0.586 & 0.041 & 775 & 0.0060 & 230 & 59 & 537 & 029 & 94 & 464 & 26 & 480 & 36 & 350 & 120 & 0.03 & 480 & 36 \\
\hline 列 & 50 & 0.260 & 240 & 0.0230 & 3.086420 & 0.2 & 00 & 48 & 2 & 1814 & 72 & 1830 & 110 & 1875 & 77 & 0.01 & 1875 & 77 \\
\hline 152 & 2.230 & 0.280 & 00 & 0.0200 & 905 & 15 & 785 & 084 & 57 & 175 & 86 & 1220 & 110 & 1180 & 200 & 0.04 & 1180 & 200 \\
\hline SC-9-Spot-153 & 3.470 & 0.190 & 0.2690 & 0.0170 & 3.717472 & 0.234933 & 0.0965 & 0.0038 & 50 & 1515 & 44 & 1527 & 85 & 1547 & 76 & 0.01 & 1547 & 76 \\
\hline SC-9-Spot-154 & 0.561 & 0.040 & 0.0677 & 0.0054 & 14.771050 & 1.178193 & 0.0589 & 0.0039 & 0.36185 & 448 & 27 & 422 & 32 & 510 & 150 & 0.06 & 422 & 2 \\
\hline
\end{tabular}


Appendix B. Continued.

\begin{tabular}{|c|c|c|c|c|c|c|c|c|c|c|c|c|c|c|c|c|c|c|}
\hline $\begin{array}{c}\text { Sample and } \\
\text { analysis number }\end{array}$ & \multicolumn{9}{|c|}{ Isotopic Ratios } & \multicolumn{6}{|c|}{ Final Isotopic Ages $(\mathrm{Ma})$} & Con. & $\begin{array}{l}\text { Plot } \\
\text { Age }\end{array}$ & $2 \sigma$ \\
\hline-9 & 757 & 49 & 951 & 083 & 0.515250 & 17735 & 0611 & 052 & 53 & 568 & 28 & 00 & 49 & 40 & 170 & .05 & 0 & 49 \\
\hline C-9-Spot-156 & 2.720 & .160 & 0.2370 & 0.0190 & 4.219409 & 0.338265 & 0872 & 0.0037 & 0.65094 & 1337 & 45 & 1365 & 97 & 1351 & 81 & 0.02 & 1351 & 81 \\
\hline SC-9-Spot-158 & 4.200 & 0.200 & 0.2870 & 0.0210 & 3.484321 & 0.254950 & 1053 & 0.0035 & 0.75629 & 1664 & 40 & 1640 & 110 & 1728 & 67 & 0.01 & 1728 & 67 \\
\hline SC-9-Spot-159 & 3.210 & 0.160 & 0.2560 & 0.0150 & 3.906250 & 0.228882 & 0956 & 0.0032 & $0.302 / 3$ & 1469 & 39 & 1462 & 77 & 1533 & 67 & 0.00 & 1533 & 67 \\
\hline SC-9-Spot-160 & 3.200 & 0.190 & 0.2480 & 0.0190 & 4.032258 & 0.308923 & 0965 & 0.0053 & 0.66534 & 1447 & 44 & 1435 & 99 & 1549 & 97 & 0.01 & 1549 & 97 \\
\hline SC-9-Spot-161 & 1.980 & 0.120 & 0.1880 & 0.0140 & 5.319149 & 0.396107 & 0.0790 & 0.0038 & 0.59328 & 1107 & 40 & 1106 & 76 & 1155 & 99 & 0.00 & 1155 & 99 \\
\hline SC-9-Spot-162 & 1.900 & 120 & 0.1740 & 0.0110 & 5.747126 & 0.363324 & 0793 & 0.0045 & 0.0001 & 1072 & 39 & 1032 & 57 & 1150 & 110 & 0.04 & 1150 & 110 \\
\hline SC-9-Spot-165 & 4.070 & 0.280 & 0.2940 & 0.0280 & 3.401361 & 0.323939 & 0.1048 & 0.0071 & 0.58091 & 1654 & 61 & 1640 & 140 & 1710 & 130 & 0.01 & 1710 & 130 \\
\hline SC-9-Spot-166 & 0.568 & 054 & 0773 & 0.0050 & 2.936610 & 0.937193 & 0042 & 0.0042 & $0.0 / 401$ & 402 & 35 & 79 & 33 & 40 & 160 & 04 & 79 & 33 \\
\hline SC-9-Spot-185 & 4.040 & 0.330 & 0.2720 & 0.0210 & 3.676471 & 0.283845 & 0.1083 & 0.0053 & 0.47734 & 1641 & 65 & 1576 & 98 & 1784 & 97 & 0.04 & 1784 & 97 \\
\hline 86 & 1.940 & 10 & 1840 & 30 & 434783 & 83979 & 774 & .0030 & 17 & 1086 & 37 & 1087 & 69 & 1121 & 79 & .00 & 1121 & 79 \\
\hline SC-9-Spot-187 & 1.710 & 0.170 & 0.1660 & 0.0130 & 6.024096 & 0.471767 & 0.0739 & 0.0060 & 0.16870 & 992 & 61 & 984 & 74 & 990 & 150 & 0.01 & 984 & 74 \\
\hline 88 & 2.710 & 00 & 40 & 00 & 4 & 257 & 40 & 39 & 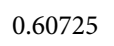 & 20 & 45 & 1340 & 100 & 1283 & 95 & 01 & 1283 & 95 \\
\hline SC-9-Spot-189 & 5.000 & 0.280 & 0.3200 & 0.0250 & 3.125000 & 0.244141 & 0.1097 & 0.0056 & 0.63141 & 1815 & 49 & 1800 & 120 & 1788 & 98 & 0.01 & 1788 & 98 \\
\hline 0 & 0 & 0.300 & 0.3070 & 0.0270 & 9 & 5 & 0 & 2 & 0.70488 & 0 & 57 & 1730 & 120 & 1694 & 7 & 02 & 1694 & 87 \\
\hline SC-9-Spot-192 & 2.350 & 0.240 & 0.2070 & 0.0170 & 4.830918 & 0.396742 & 0.0842 & 0.0047 & 0.13455 & 1212 & 74 & 1205 & 92 & 1250 & 110 & 0.01 & 1250 & 110 \\
\hline SC-9-Spot-199 & 2.580 & 0.160 & 0.2170 & 0.0170 & 4.608295 & 0.361019 & 0.0877 & 0.0047 & 0.65302 & 1298 & 46 & 1259 & 89 & 1400 & 110 & 0.03 & 1400 & 110 \\
\hline 0 & 1600 & 077 & $70 \pi$ & 0.0089 & 5.85 & 8 & 0 & 1 & 0.63753 & 10 & 28 & 1014 & 49 & 956 & 6 & 01 & 6 & 6 \\
\hline SC-9-Spot-201 & 1.730 & 0.110 & 0.1700 & 0.0110 & 5.882353 & 0.380623 & 0.0747 & 0.0050 & 0.55085 & 1010 & 39 & 1009 & 58 & 1110 & 120 & 0.00 & 1110 & 120 \\
\hline SC-9-Spot-202 & 3.050 & 0.100 & 0.2460 & 0.0120 & 1 & 5 & 5 & 6 & 0.67518 & 1 & 26 & 1 & 60 & 70 & 100 & 00 & 1370 & 0 \\
\hline SC-9-Spot-203 & 5.100 & 0.370 & 0.3430 & 0.0360 & 2.915452 & 0.314495 & 0.1081 & 0.0064 & 0.79525 & 1834 & 62 & 1880 & 170 & 1740 & 110 & 0.02 & 1740 & 110 \\
\hline SC-9-Spot-204 & 3 & 0.110 & 0.2340 & 0.0160 & 4 & 5 & 0.0969 & 9 & 0.77197 & 4 & 28 & 50 & 84 & 70 & 4 & .04 & 1570 & 4 \\
\hline SC-9-Spot-205 & 0.586 & 0.047 & 0.0733 & 0.0050 & 13.642560 & 0.930598 & 0.0559 & 0.0046 & 0.33563 & 53 & 30 & 55 & 30 & 10 & 170 & 0.02 & 455 & 30 \\
\hline sc & 4.180 & 0.190 & 0.2980 & 10 & 05 & 476 & 3 & 46 & 0.74691 & 1667 & 39 & 70 & 110 & 50 & 85 & 0.00 & 1650 & 5 \\
\hline SC-9-Spot-207 & 3.250 & 0.130 & 0.2470 & 0.0130 & 4.048583 & 0.213083 & 944 & 0.0033 & 17 & 1464 & 32 & 1420 & 66 & 1519 & 68 & .03 & 1519 & 68 \\
\hline SC-9- & 3.810 & 0.250 & 2740 & 0.0180 & 3.649635 & 39757 & 0.0996 & 0.0066 & 0.6 & 1605 & 52 & 1556 & 91 & 1580 & 120 & 0.03 & 1580 & 120 \\
\hline SC- & 1. & 0 & 0.1810 & 0 & 5.524862 & 0.335765 & 748 & 0.0039 & 303 & 76 & 39 & 1071 & 62 & 1090 & 100 & .00 & 1090 & 100 \\
\hline SC-9-S & 3.280 & 0.130 & 0.2500 & 0.0160 & 4.000000 & 0.256000 & 0.0938 & 0.0038 & 0.78310 & 1470 & 31 & 1434 & 81 & 1502 & 78 & 0.03 & 1502 & 78 \\
\hline SC & 2 & 0.100 & 0.1910 & 0.0120 & 5.2356 & 0.328 & 0 & 0.0036 & $062->$ & 1154 & 33 & 1121 & 65 & 1195 & 92 & 03 & 95 & 2 \\
\hline SC-9-Spot-212 & 2.530 & 0.140 & 0.2080 & 0.0140 & 4.807692 & 0.323595 & 0.0835 & 0.0036 & 0.64790 & 1270 & 40 & 1216 & 72 & 1268 & 90 & 0.04 & 1268 & 90 \\
\hline 10 & 5.250 & 0.180 & 0.3280 & 0 & 0 & 1 & 0.1165 & 3 & 0.70811 & 0 & 29 & 1822 & 70 & 01 & 50 & 02 & 01 & 0 \\
\hline SC-9-Spot-214 & 3.840 & 0.190 & 0.2830 & 0.0170 & 3.533569 & 0.212264 & 0.1021 & 0.0039 & 0.56539 & 1598 & 41 & 1601 & 87 & 1640 & 72 & 0.00 & 1640 & 72 \\
\hline
\end{tabular}


Appendix B. Continued.

\begin{tabular}{|c|c|c|c|c|c|c|c|c|c|c|c|c|c|c|c|c|c|c|}
\hline \multirow[b]{2}{*}{$\begin{array}{c}\text { Sample and } \\
\text { analysis number }\end{array}$} & \multicolumn{9}{|c|}{ Isotopic Ratios } & \multicolumn{6}{|c|}{ Final Isotopic Ages (Ma) } & \multirow[b]{2}{*}{ Con. } & \multirow[b]{2}{*}{$\begin{array}{l}\text { Plot } \\
\text { Age }\end{array}$} & \multirow[b]{2}{*}{$2 \sigma$} \\
\hline & $\begin{array}{l}{ }^{207} \mathrm{~Pb} / \\
{ }^{235} \mathrm{U}\end{array}$ & $2 \sigma$ & $\begin{array}{l}{ }^{206} \mathrm{~Pb} / \\
{ }^{238} \mathrm{U}\end{array}$ & $2 \sigma$ & $\begin{array}{l}{ }^{238} \mathrm{U} / \\
{ }^{206} \mathrm{~Pb}\end{array}$ & $2 \sigma$ & $\begin{array}{l}{ }^{207} \mathrm{~Pb} / \\
{ }^{206} \mathrm{~Pb}\end{array}$ & $2 \sigma$ & $\mathrm{C}$ & $\begin{array}{l}{ }^{207} \mathrm{~Pb} / \\
{ }^{235} \mathrm{U}\end{array}$ & $2 \sigma$ & $\begin{array}{l}{ }^{206} \mathrm{~Pb} / \\
{ }^{238} \mathrm{U}\end{array}$ & $2 \sigma$ & $\begin{array}{l}{ }^{207} \mathrm{~Pb} / \\
{ }^{206} \mathrm{~Pb}\end{array}$ & $2 \sigma$ & & & \\
\hline SC-9-Spot-215 & 6.680 & 0.180 & 0.2830 & 0.0150 & 3.533569 & 0.187292 & 2 & 52 & 5 & 2067 & 24 & 1602 & 77 & 2581 & 60 & 0.29 & -- & --- \\
\hline SC-9-Spot-216 & 2.960 & 0.120 & 0.2410 & 0.0190 & 4.149378 & 0.327129 & 0.0921 & 0.0041 & 0.82799 & 1391 & 31 & 1383 & 96 & 1453 & 89 & 0.01 & 1453 & 89 \\
\hline SC-9-Spot-236 & 3.810 & 0.170 & 0.2600 & 0.0150 & 3.846154 & 0.221894 & 0.1068 & 0.0038 & 0.63174 & 1594 & 36 & 1482 & 79 & 1726 & 67 & 0.08 & 1726 & 67 \\
\hline SC-9-Spot-237 & 3.880 & 0.170 & 0.2830 & 0.0190 & 3.533569 & 0.237236 & 0.1019 & 0.0041 & 0.70234 & 1602 & 35 & 1599 & 93 & 1635 & 76 & 0.00 & 1635 & 76 \\
\hline SC-9-Spot-238 & 5.030 & 0.210 & 0.3190 & 0.0190 & 3.134796 & 0.186712 & 0.1152 & 0.0044 & 0.782 & 1818 & 35 & 1775 & 94 & 1876 & 67 & 0.02 & 1876 & 67 \\
\hline SC-9-Spot-239 & 4.040 & 0.180 & 0.2920 & 0.0200 & 3.424658 & 0.234566 & 0.1026 & 0.0043 & 0.65069 & 1648 & 37 & 1644 & 97 & 1659 & 82 & 0.00 & 1659 & 82 \\
\hline SC-9-Spot-243 & 4.480 & 0.150 & 0.3060 & 0.0180 & 3.267974 & 0.192234 & 0.1053 & 0.0043 & 0.82284 & 1723 & 29 & 1712 & 91 & 1721 & 74 & 0.01 & 1721 & 74 \\
\hline SC-9-Spot-244 & 5.430 & 0.250 & 0.3370 & 0.0260 & 2.967359 & 0.228936 & 0.1176 & 0.0070 & 0.83304 & 1883 & 40 & 1880 & 120 & 1880 & 100 & 0.00 & 1880 & 100 \\
\hline SC-9-Spot-245 & 1.854 & 0.098 & 0.1790 & 0.0110 & 5.586592 & 0.343310 & 0.0747 & 0.0039 & 0.51943 & 1058 & 35 & 1060 & 61 & 1040 & 110 & 0.00 & 1040 & 110 \\
\hline SC-9-Spot-246 & 3.870 & 0.130 & 0.2750 & 0.0140 & 3.636364 & 0.185124 & 0.0993 & 0.0033 & 0.61557 & 1615 & 26 & 1561 & 71 & 1603 & 64 & 0.03 & 1603 & 64 \\
\hline SC-9-Spot-247 & 1.920 & 0.120 & 0.1770 & 0.0120 & 5.649718 & 0.383032 & 0.0 & 0.0044 & 0.55726 & 0 & 42 & 1056 & 64 & 1170 & 110 & 0.02 & 1170 & 110 \\
\hline SC-9-Spot-248 & 1.678 & 0.077 & 0.1570 & 0.0110 & 6.369427 & 0.446266 & 0.0753 & 0.0042 & 0.56950 & 997 & 29 & 939 & 59 & 1050 & 110 & 0.06 & 939 & 59 \\
\hline SC-9-Spot-250 & 1.681 & 0.093 & 0.1686 & 0.0086 & 5.931198 & 0.302540 & 0.0725 & 0.0039 & 041552 & 1012 & 36 & 1003 & 47 & 1016 & 96 & 0.01 & 16 & 96 \\
\hline SC-9-Spot-251 & 1.664 & 0.070 & 0.1638 & 0.0098 & 6.105006 & 0.365257 & 0.0727 & 0.0032 & 0.75565 & 991 & 27 & 975 & 54 & 975 & 90 & 0.02 & 975 & 54 \\
\hline SC-9-Spot-252 & 1.890 & 0.100 & 0.1800 & 0.0120 & 5.555556 & 0.370370 & 0.0753 & 0.0049 & 06724 & 1075 & 37 & 1063 & 68 & 1070 & 30 & 0.01 & 1070 & 130 \\
\hline SC-9-Spot-259 & 2.007 & 0.082 & 0.1870 & 0.0100 & 5.347594 & 0.285968 & 0.0766 & 0.0034 & 0.64733 & 1113 & 27 & 1103 & 54 & 1117 & 90 & 0.01 & 1117 & 90 \\
\hline SC-9-Spot-260 & 1.788 & 0.072 & 0.1726 & 0.0085 & 5.793743 & 0.285323 & 0.0740 & 0.0024 & 0.62078 & 1041 & 27 & 1024 & 47 & 1044 & 69 & 0.02 & 1044 & 69 \\
\hline SC-9-Spot-261 & 3.390 & 0.150 & 0.2610 & 0.0130 & 3.831418 & 0.190837 & 0.0946 & 0.0028 & 0.53354 & 1506 & 34 & 1492 & 67 & 1506 & 58 & 0.01 & 1506 & 58 \\
\hline SC-9-Spot-262 & 1.840 & 0.110 & 0.1771 & 0.0084 & 5.646527 & 0.267820 & 0.0752 & 0.0034 & 0.27340 & 1056 & 38 & 1049 & 46 & 1090 & 100 & 0.01 & 1090 & 100 \\
\hline SC-9-Spot-263 & 1.499 & 0.087 & 0.1580 & 0.0084 & 6.329114 & 0.336485 & 0.0682 & 0.0040 & 0.46595 & 22 & 36 & 944 & 47 & 840 & 120 & 0.02 & 944 & 77 \\
\hline SC-9-Spot-264 & 1.733 & 0.056 & 0.1657 & 0.0068 & 6.035003 & 0.247665 & 0.0749 & 0.0026 & 0.55259 & 1018 & 21 & 994 & 39 & 1068 & 68 & 0.02 & 994 & 39 \\
\hline SC-9-Spot-265 & 1.995 & 0.084 & 0.1890 & 0.0100 & 5.291005 & 0.279947 & 0.0781 & 0.0033 & 0.68572 & 1113 & 28 & 1121 & 54 & 1165 & 81 & 0.01 & 1165 & 1 \\
\hline SC-9-Spot-266 & 11.040 & 0.440 & 0.4310 & 0.0260 & 2.320186 & 0.139965 & 0.1869 & 0.0074 & 0.80790 & 2524 & 35 & 2300 & 120 & 2695 & 66 & 0.10 & 2695 & 66 \\
\hline
\end{tabular}

